The Stockmen's Legal Guide

\title{
For Nebraska and Iowa
}

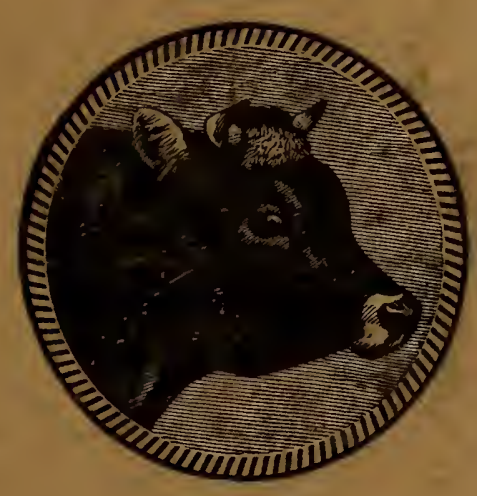

\author{
PUBLISHED BY
}

Stockmen's Claim Association OMAHA, NEBRASKA 


\section{.. The ... \\ PACKERS \\ National Bank \\ South Omaha, Neb.}

Capital and Surplus $\$ 300,000.00$

J. F. COAD, President

WM. J. COAD, Vice-Pres.

H. C. NICHOLSON, Cashier

H. F. Trumble, $\Lambda$ ss't ('ash.

T. J. Shanahan, Ass't Cash.
All branches of banking in connection with the Live Stock Industry

$4 \%$ Interest Paid on Time Deposits

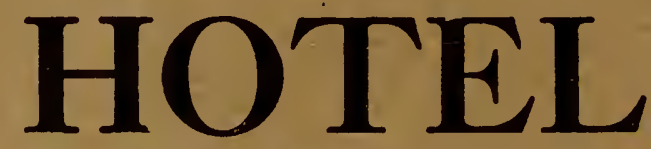

DAVENPORT

J. C. Humphreys, Proprietor

Electric Lghts

.. Steam Heat..

American or European

Rooms 50c, 75c, $\$ 1.00$

Bar in connection $1 / 2$ block East 310-12-14 Virginia Street

Sioux City, - -:- Iowa 


\section{Cox - Jones - Van Alstine Co.}

Successful Handlers of Live Stock

Experienced salesmen in each department. Efflcient Yard help. Good fills a specialty. We handle Cattle, Hogs and Sheep on commission only. We buy cattle and sheep on orders. Buying the right kind at the lowest market price. Our increasing business from year to year proves our net results give the satisfaction our customers want.

Try us and be Convinced. Remember Us With Your Next Consignment

\section{So. Omaha, Neb. \\ Denver, Colo.}

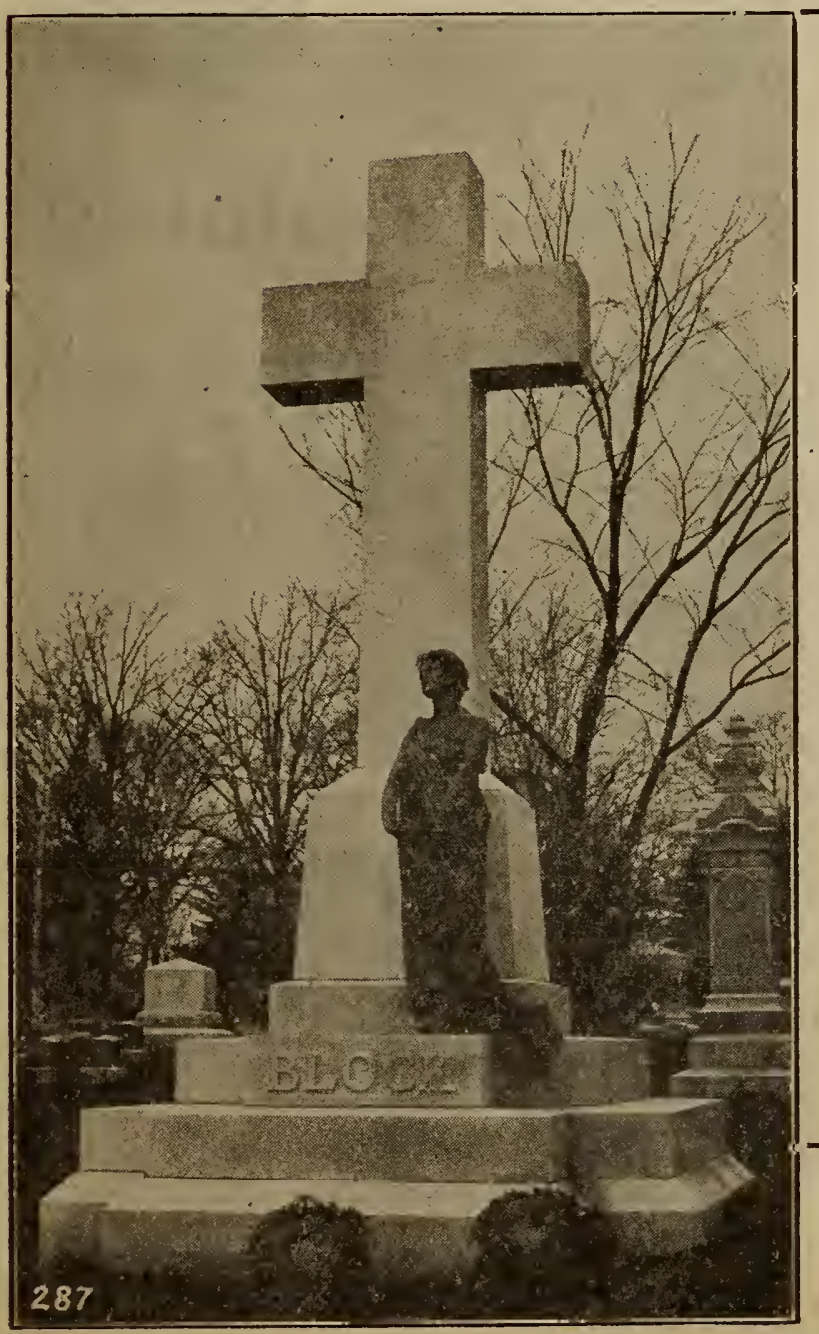

\section{FRANK \\ SVOBODA}

\section{High - Class \\ Monuments}

\section{Laroest Display}

In the U. S.

1215-31

South 13th Street OMAHA

Phone Doug. 1872

I can Save

You Money 


\section{D From Farm to Tannery From Tannery to Farm}

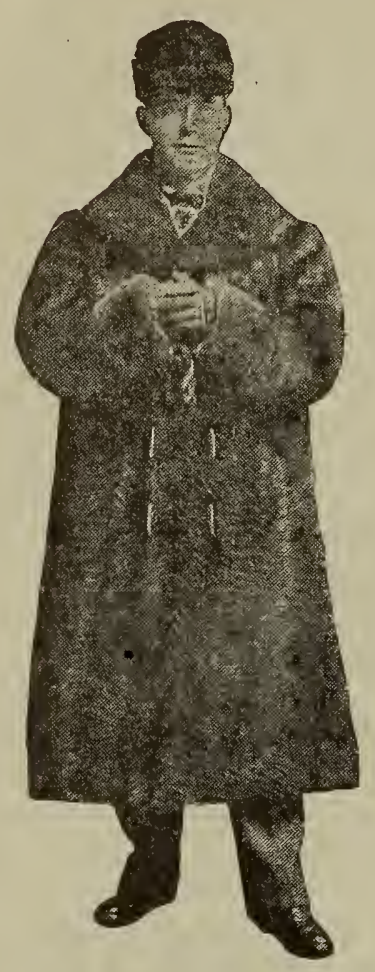

\section{We Will Tan}

your hides and furs and make them into coats, robes, muffs, scarfs, etc.

\section{or}

\section{We Will Buy}

them direct from you at full market value for spot cash.

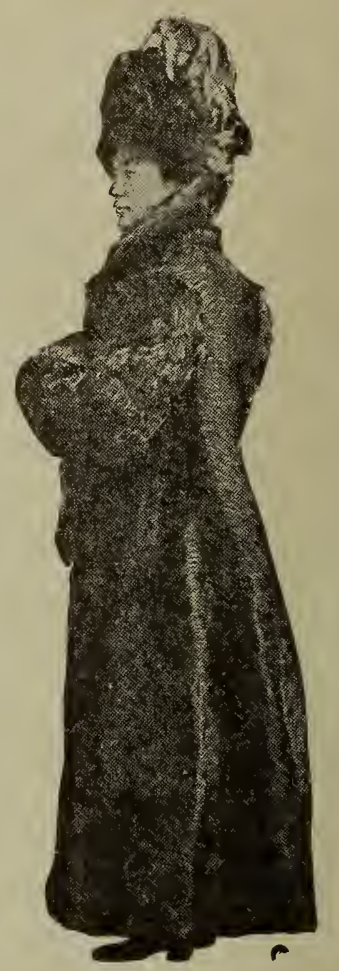

\section{Send for Our Catalog}

If you need leather or fur goods or taxidermy or fur repairing, it will pay you to know us. We are the largest fur tanning and manufacturing concern in the west.

Call at Our Factory When in Omaha National Fur \& Tanning Co. 1925 South 13th St. OMAHA, NEB. 


\title{
STOCKMEN'S
}

\section{LEGAL GUIDE}

\section{NEBRASKA-IOWA EDITION}

\section{Price \$1.00, Postpaid}

\author{
(Copywrited 1914 by J. C. Travis)
}

\section{PUBLISHED BY}

Stockmen's Claim Association

Omaha, Nebraska 


\section{Wonderful Treatment for Rheumatism and Many Chronic Diseases}

Awarded Gold Medal and International Diploma at "St. Louis Exposition as being the Most Perfect Bath in the World.

\section{Moorefield's Medicated}

\section{Sulphur Steam Baths}

\section{We positively give relief to all sufferers of rheu- matism. Our patrons are our best reference.}

THESE BATHS have no weakening effect, but strengthen and exhilarate in every case.

They may be taken on the coldest day without danger of taking cold.

They have the greatest cleansing power of any Bath in the World.

We cure when all the noted Springs and the many different Baths fail.

Why leave home and business for treatment when you can be cured at home at less expense while attending to your business.

SKIN DISEASES.

These Baths help the skin to throw off impurities and make the complexion clear and beautiful.

\section{FEMALE WEAKNESSES.}

It is a God-send to suffering women, bringing great relief for many serious troubles.

\section{DRUNKENNESS.}

We can cure any case of Inebriety in two hours, leaving the $\mathrm{p}$ tient with no bad feeling.

If you have a case which the doctors and other baths have failed to cure, come and investigate. We can cure' you.

These Baths will help you if you are well.

They are pleasant to take.

Try them; you will be delighted.

If you would attain greater physical perfection or ward off the advances of age you cannot afford to neglect these Baths.

-While the patient lies naturally, it causes every nerve and muscle to relax, the head resting on a pillow outsicie the tub.

Medicated vapor of a proper heat causes the impurities of the systiem to exude through the pores of the skin.

This Bath will take the impurities of whatever nature, out of your system and make you feel young again.

Baths $\$ 1.00$; Six for $\$ 5.00$.

Massage $\$ 1.00$; Six ior seç.

Lady attendant for Ladies from $s \cdot a$, m. to $6 \mathrm{p}$. m., or any time by appointment.

\section{JOHN A. SOLOMON \\ Proprietor}

507 No. 24th St., SOUTH OMAHA, NEB.

Bell Phone South 2992 Opposite Postoffice. 


\section{Introduction}

Every man is presumed to know the law, and ignorance of the law is no excuse for a riolation of it-so say the maxims. It is however, utterly impracticable for every man to be a lawyer and know all the laws, yet it is practicable for him to be at least passingly familiar with those. laws which govern and control his business.

The laws are the rules and regulations which he is forced to observe for the protection and well-being of himself and his fellowman.

And especially is this true of the stockman. There is, perhaps, no set of men engaged in any business in this state who are so constantly being brought face to face with circumstances and situations which place their rights in jeopardy as is the stockman. Every time he ships in a stallion, a bull or a boar-every time he places them in his fields on the range-every time he ships his stock to market-he is surrounding himself with a perfect maze of duties which must be performed on his part and on the part of others that no one will be damnified.

And he should know just what his rights are under any given case-"forewarned is forearmed."

It is because of these facts that this book has been compiled and written. It sets forth the laws as they were created by statute, with certain decisions of the State Supreme Court and the United States Supreme Court interpreting them-which decisions form the nucleus of the various articles.

The author claims no originality of thought in this book-in fact the converse is true. These laws began in their formation upon the beginning of man and are the outgrowth of centuries upon centuries of careful thought and study of the wisest sages of each generationeach generation weeding out the bad and replacing them with good, modifying and extending them and finally handing them down to the succeeding generation for its revision-eventually reaching us in the year 1913 in their present form.

The author does claim, however, that a passing familiarity with the laws contained in this book will mean the saving of hundreds of thousands of dollars annually to the stockmen.

An erroneous impression is sometimes found current as to the conduct of business in a stock yards. It is not infrequently found that the stock yards, the commission houses and the packers are all confounded as one institution. Three separate and distinct branches of business are found in the conduct of the live stock business at all stock yards. The Stock Yards company does not do a business in 


\section{Stockmen's Claim Association}

Stock Claims

Freight Claim Adjusters

Common Law Carrier

Bee Bldg. Omaha, Neh.

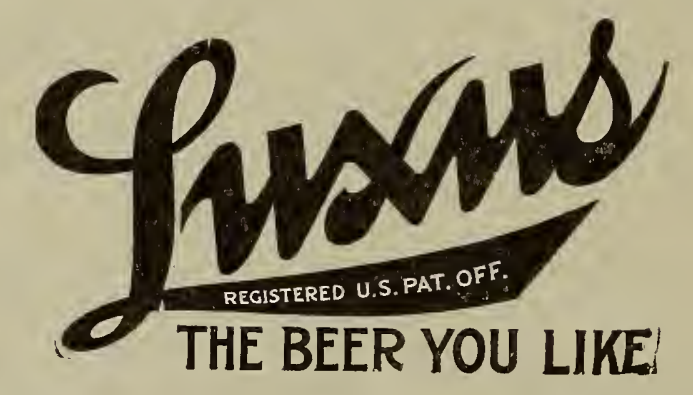

No Beer Better Made

No Better Beer Made

Brewed and Bottled by

Fred Krug Brewing Company OMAHA, U. S. A.

Luxus Mercantile Co. 109-11 N. 16th St. Opposite Post Office 
the buying and selling of live stock; it is an institution that furnishes yards for the concentration and handling of live stock; its revenues are derived from pen rental and feed charges. The live stock commission man is not a buyer and seller of cattle, hog's and sheep; he is the agent of the producer and handles the stock through the yards for a commission paid by the seller; he does not make his revenues by the purchase and sale of stock; he is the medium between the original owner and the packer. The packer does not speculate in live stock in the yards; he buys the live stock, takes it to the abattoir and there proceeds by different processes to transform that.stock into merchantable packing house products.

However, not all of the live stock arriving in the stock vards goes direct to the packers. The stock yards has another market. Much of the stock arriving at the yards is unfic for killing. Large numbers of this class of stock, cattle and sheep, especially, are brought by farmers to be taken back to the country to be fed out and made ready for the slaughter house and the meat block.

THE AUTHOR. 
SIOUX CITY'S FOREMOST CLOTHES STORE
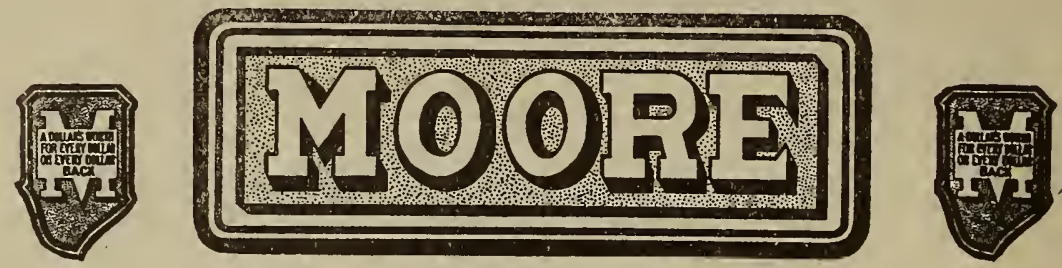

FOURTH AND NEBRASKA STS.

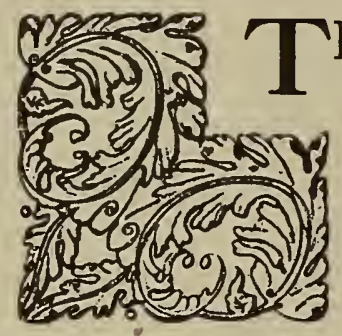

THIS store is often a revelation to people when first they come here for a look or to buy. Here only merchandise of known quality and worth is sold-add to it the advantage of low price and perfect service and the result is Satisfaction.

OUR GUARANTEE

$A$ Dollar's Worth for Every Dollar or Every Dollar Back, takes positive care of that.

KUPPENHEIMER GLOTHES STETSON HATS

\section{The Moore Clothing Co.} Sioux City, - - Iowa 


\section{Law Offices of JOHN O. YEISER \\ Bee Building \\ Omaha.}

\section{To Whom It May Concern:}

This is to certify that I have examined the manuscript for this publication with a view of determining whether or not the same contains a substantial statement of the laws.

While I have not made a clerical comparison still I was unable to detect any errors.

I am very much impressed with the value of this publication to farmers and stockmen.

Sincerely yours,

(Signed) JOHN O. YEISER. 
Wm. C. R. Nollmann,

A. A. Kruse,

Pres.

Omaha Marble

\section{\& Tile Company}

Tile Work-

Bath Rooms, Vestibules, Floors.

Onyx and Marble-

Floors, Stairs, Wainscot.

Terrazzo-

Floors, Base.

Mantels-

Grates, Andirons.

Terra Cotta-

Structural Slate, Slate Blackboards.

Roofing-

Slate, Tile and Gravel.

110-112 N. 14th St. Omaha, Neb. 


\section{How to Collect Claims}

Important Suggestions promulgated by Carriers to Secure the Cooperation of the Shipping Public, Endorsed by the Freight

Claim Association, Comprising Practically All Carriers in the United States, Canada and Mexicc.

Honest, frank and hearty co-operation on the part of claimant in presenting claim with proper evidence does much to expedite settlement. The policy of carriers today is to establish the validity of a claim and not to avoid liability.

The Freight Claim Agent is bound to live within the scope of the law and cannot subject himself, his Company or the claimant to the severe fines and penalties imposed by law by paying claims until the facts and measure of legal liability are established. ("It is not the proper practice for railroad companies to adjust claims immediately on presentation and without investigation. The fact that shippers may give a bond to secure repayment in case, upon subsequent examinations, the claims prove to have been improperly adjusted, does not justify the practice." Extract from Interstate Commerce Commission Bulletin No. 3, Article No. 68.)

Any loss or damage, immediately on discovery, should be reported to the Agent of the delivering line, and every opportunity should be afforded him to inspect and verify the same, and in no case should report of this loss or damage be delayed beyond forty-eight hours after receipt of goods.

Delay in making complete investigation is sometimes unavoidable on account of the numerous agencies involved. It must be borne in mind that every claim must undergo some investigation, since reports of loss or damage are not always at the finger tips of the Claim Department.

Delay in adjusting claims for damages often arises through the refusal of consignee to accept property which has been delayed or damaged in transit. It should be understood that the acceptance of such delayed or damaged property does not in any way jeopardize any proper claim which the owner may have against the carrier; in fact, the law expressly provides that a consignee must accept his own property and use all diligence in disposing of it with a view of minimizing loss.

If a carrier fails to acknowledge receipt of a claim, it is an oversight. In acknowledging receipt of claims the official in charge of the Claim Department furnishes a claim number under which all correspondence pertaining to that claim is handled, and it would very much expedite the work in the freight claim office if reference was made to this claim number in any correspondence from claimant or on statements of account periodically sent. 


\section{Purity, Quality THE TASTE TELLS Age 100\% Goldstrom's Straight Pure Whiskey}

The constant demand for a pure $100 \%$ straight Whiskey has placed us in a position to give you the best value for the money. This Whiskey is a 2-stamp, fine, mellow whiskey, put up by us in one-gallon glass bottl $\epsilon_{\mathbb{S}}$ with our 15 years of bulsiness guarantee behind it. For medicinal use and purity it has no equal. Every bottle has the green stamp with 100 per cent proof on same to assure you that we want to give you fine quality Whiskey. A'l we ask is a trial order. Money refunded if not satisf.ed. This Whiskey is distilled for us in Registered Dist. No. 1, of Nebraska, from Nebraska and Iowa's choice grain. Patronize your home market. Why send away for your liquors when you can get the same at home? We give prompt delivery. All goods shipped in plain boxes same day on receipt of ordcr. Don't delay. Order today.

Glass and Corkscrew FREE with each order

Goldstrom's Straight 4-year-old Whiskey,

1-gallon bottle, express prepaid .............

2-gal. jug or two 1-gal. bottles....................................................\$6.00

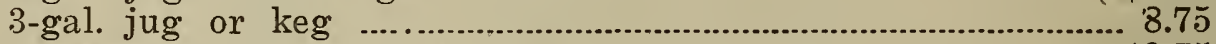

5-gal. keg or five 1-gal. jugs .........................................................13.75

Orders for Wyoming, Colorado, Idaho, North and So. Dakota, Montana Oregon and Washington must call for 5 gallons or more to be prepaid. To customers desiring quantities of this Whiskey by the barrel or half-barrel, we will make special prices.

Send for Complete Price List.

SOL. S. GOLDSTROM DISTRIBUTING COMPANY Box 66 Stock Yards Branch, So. Omaha, Neb.

\section{Get a Delightful Home or a Profitable Investment with a Large Future Income in Polk County FLORIDA}

FLORIDA has the most delightful climate in the United States. $P O L K C O$. land is the cream of the state for oranges and grapefruit.

POLK CO. shipped 58,000 boxes more, the past year, than any other Co.

POLK $C O$. has 500 beautiful clear lakes, moderating the air all the year; No snow no "Blizzards". Boating, Bathing, Fishing, Autoing; Golf and Ball; Fresh Vegetables and Ripe Strawberries are winter delights. If you were there wouldn't you think that delightful?

$M Y$ POLK CO. land, set to grove would cost you around $\$ 150$ per acre. Properly cared for 5 years, it is worth $\$ 500$ per acre. Isn't that good profit?

This Orange and Grapefruit grove, after 5 years old, will yield $\$ 100$ to $\$ 1,000$ per acre' net. Isn't that a nice income? Wouldn't you like 10 or 20 acres? Mr. Koplin last year sold his fruit.from $71 / 2$ acres for $\$ 11,900.00$ Mr Stephens sold his fruit from a 5acre grove for $\$ 8,000.00$ net. Both in FOLK CO.

My raw land in POLK CO. prices $\$ 40$ to $\$ 100$ per acre. It will pay you to investigate this. Write NOW for literature telling you all about it. Call personally if you can. Address

\section{G. SOMERS}

882 Brandeis Building,

Omaha, Nebraska. 


\section{TABLE OF CONTENTS}

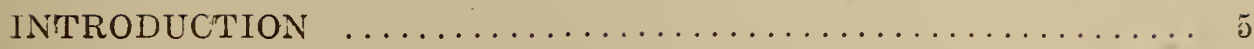

HOW TO COLLECT CLAIMS.................... 11

NEBRASKA LAWS:

Laws Covering a Shipment.................. 1 j

Common Carrıer Liability ................... 21

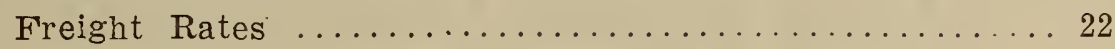

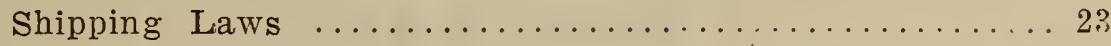

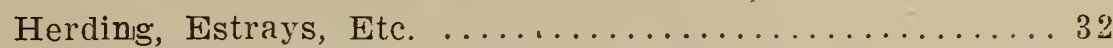

Diseased Stock and Quarantine Laws.............. 38

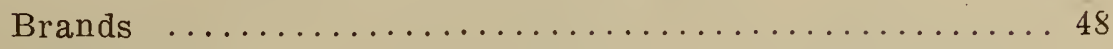

Stallion Laws .......................... 51

Criminal-Animals .................... 57

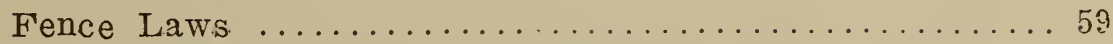

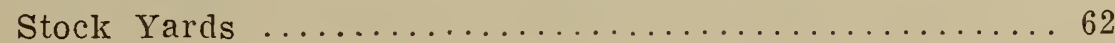

Liens on Live Stock.................... 63

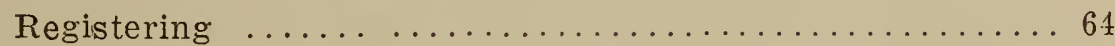

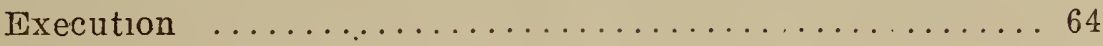

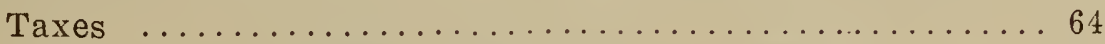

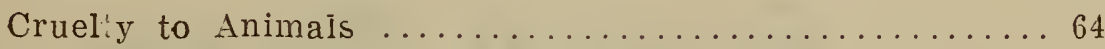

IOWA LAWS:

Stallions, Jacks and Registered Pedigreed Stock.......6 65

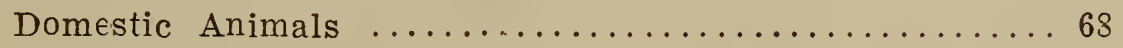

Live Stock Running at Large................. 73

Criminal-Animals $\ldots \ldots \ldots \ldots \ldots \ldots \ldots \ldots \ldots \ldots \ldots$

Diseased Stock and Quarantme Laws..............70

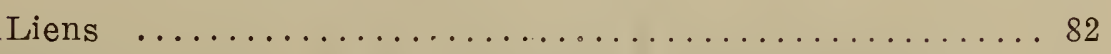

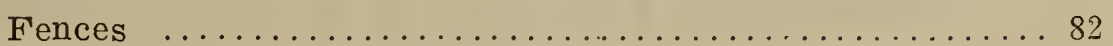

Commission of Animal Health............... 87

Associations for Promotion of Live Stock Industry...... 88

Dairy and Beef Cattle Indus.ry.............. 90

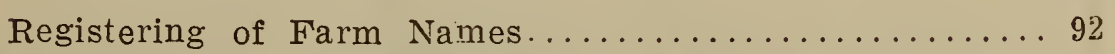

UNITED STATES LAWS AND SANITAFY REGULATIONS..... 93

RAILPOAD RULES AND RFGULATIONS................119 
The Birthplace of advanced ideas in the handling of Live Stock

\section{Rice Brothers \\ Live Stock Commission Merchants}

Sioux City

Chicago

Kansas City

The home of "SERVICE THAT SERVES."

\section{Geidel = Brau ... And... \\ Western Brew}

Bottled Beers are the Best

\section{SIOUX CITY BREWING COMPANY}

Sioux City, - - - lowa 


\section{Stockmen's Legal Guide}

NEBRASKA LAWS

\section{Laws Covering a Shipment}

THE CARS.

Upon determining to ship, the stockmen should give his order to the railroad company for the desired number of cars, stating the size, class (single or double deck), etc., and should confirm his order in writing immediately. Should he desire a special car, such as a "Palace Stock Car", his order should so specify.

These car's must be furnished promptly and without discrimination and set at the desired point. They must also be safe and suitable for the transportation of stock, and, in order to make them such, should contain an adequate amount of bedding. Under all circumstances the railroad company must comply with the provisions.

\section{LOADING.}

Unless otherwise stipulated and agreed the railroad company must load the stock in the cars, and will be liable for any negligence on their part in so doing. The shipper, however, may by agreement load the cars in which event he would be liable for any damage, excepting, of course, any damage the outcome of unsafe equipment furnished him or negligence on the part of the railroad company. The stock must be loaded by the railroad without unreasonable delay and when loaded must be placed in the train without any unreasonable delay.

\section{RAILROAD PENS.}

Shipping yards and pens must be maintained by the various railroad companies. The railroad company's pens must contain safe sheds for the protection of hogs at all shipping yards from which not less than forty cars of hogs are shipped a year and the shipping yards must be able to afford shelter for at least one car of hogs and the capacity of the shed protection must be increased so as to take care of one additional car of hogs for each additional forty cars shipped from such station yearly but in no event need the sheds be built to accomodate more than four cars of hogs at any one time. It is a misdemeanor for the railroad company to violate any of the above provisions and punishable by fine of not less than five dollars per day for every day of such failure or neglect. The State Railway Commission is empowered and it is their duty to enforce these provisions. A railroad company is liable to the shipper for injury to stock caused by these pens being defective or any other injury caused by failure to properly maintain these sheds in accordance with the above provisions.

\section{PRIVATE SHIPPING PENS.}

Private shipping pens are established as follows: Any shipper or association of shippers desiring to establish private shipping pens makes application to the railroad company in writing, setting forth the probable amount of livestock to be shipped during the next twelve months and giving the space desired on the company's right of way on which to erect sheds for temporary shelter of livestock while awaiting shipment. This application must specifically set forth the plans for said shed, their position with reference to the railroad 
tracks and shipping pens, together with any facts or arguments as to why the application should be granted, and this application should be filed with the local agent at any station of such railroad.

In case the application is rejected and an agreement cannot be reached, the applicant may present his petition to the State Railway Commission, reciting the facts set forth in the application and praying for relief. The State Railway Commission will thereupon set a time for hearing upon the petition, make a thorough investigation of the facts and conditions set forth and issue such an order as may be reasonable and within the powers of the Commission. Should the railroad company refuse to comply with the order of the Commission within thirty days after its issuance, it will be liable to a fine of not more than one hundred dollars and for any loss sustained by livestock shippers because of such failure.

However, it must be kept in mind that the railroad company is not liable under any of the provisions set forth, for the destruction of the sheds or structures, any damage thereto or destruction or damage to animals contained therein. The shipper assumes that risk.

\section{PRIVATE SIDE-TRACK.}

A shipper may have a private side-track established, equipped and maintained, at which to load and unload his stock if it appears to be reasonable and just that such side-track should be established. These side-tracks may be built wholly at the expense of the railroad company; partially at their expense (according to whether or not the establishing of such tracks would be justified by the amount of revenue derived from such) or wholly at the expense of the shipper. It must, however, appear that it would be warranted by the amount of revenue derived.

Under this statute the railroad company must treat all persons and corporations fairly and equally and without discrimination or favoritism in this regard and any person who is dissatisfied with the amount required to be paid by him towards the construction of such track may bring civil action and have the issues judicially determined.

After such determination then, should the company fail for sixty days to comply with the decision of the Court the person so aggrieved may file his petition again in the District Court of the County in which his industry is carried on, and deposit or enter into sufficient security for the payment to be made on his part toward the construction of such track, together with a statement that he is ready, willing and able to comply with the orders of the Court in the first case. Whereupon the Court shall grant any appropriate relief authorized by law.

\section{STOCK IN PENS.}

Immediately upon the delivery of the livestock by the shipper and their being accepted by the railroad company the railroad company's liability commences. The general rule is that a common carrier is an insurer of the safe delivery of the livestock. The delivery to a railroad company of livestock in good condition and the arrival of the livestock at destination in bad condition makes a prima facie case against the carrier. The railiroad company is liable' for any loss or injury from whatever cause arising, excepting only the act of God or the public enemy. By "the act of God or the public enemy" is meant such things as canno's be foreseen and guarded against. For instance: A washout is of common occurrence and should be guarded against and the carrier is held liable for any damages caused thereby. But in the case of a tornado or a stroke of lightning it is different-it would be impossible to guard against either of them and to hold a carrier liable would be an injustice.

While the railroad company is not an insurer of the arrival of its 


\section{Great Western Commission Co.}

Your best interests cared for in every particular. Ship your live stock to them or send them your orders for feeding stock. They are specialists in both selling and buying.

So. Omaha, Neb.

Denver, Colo.

\section{H. W. BINDER \\ Farm Loans}

Loans made on Nebraska farms at lowest rates-with privilege of prepayment on interest dates.

820-825 City Nat'l Bank Bldg.
Omaha,
$-:-$
$\therefore-$
Nebraska 


\section{While In Omaha}

QHave your teeth properly attended to by Expert Dentists. पThe best of workmanship, the best of materials and at reasonable rates, insures perfect satisfaction $\downarrow$

Vitalized Air for Painless Extraction

\section{Taft's Dental Rooms}

1517 Douglas St.,

Omaha, Neb.

Westover

\& True

Auto and Taxi Livery

Prompt Service Day or Night

Stockman's Trade a Spécialty

OMAHA, NEB.
Wyckoff-Cord

Auto \& Taxi

Company

Sioux Gity, Iowa

Rates

Reasonable

Stockman's Trade a Specialty

Phone, Iowa 1501 409 4th Street 
trains on schedule time, still in case of a material delay the company must show that the delay was caused by some other than its own negligence.

The railroad company is not liable for damage to stock placed in the yards for subsequent shipment, the owner retaining the right to remove them before shipment and in such case the company's liability is that of an ordinary bailee.

\section{THE CONTRACT.}

Under the constitution of the state of Nebraska "The liability of railroad corporations as common carriers shall never be limited" and, hence, any attempt to do so would be unconstitutional.

Any provision in a contract, binding upon the initial carrier, is binding upon its connection carriers. A railroad taking a shipment to be transported over its line to a certain junction and there transferred to another railroad for further transportation, binds both itself and the connecting carrier and both are liable in event of damage.

Blooded animals and valuable animals should be so stated and release valuation so stated. The decisions in this regard hold that a common carrier cannot release its liability to any amount less than the actual value of the stock and state that any provision in a contract attempting to so limit it is void-this on an intra-state ("in the state") shipments but hold that on an inte'r-state ("from state to state") shipment the provision is good. Thus, a hog valued at $\$ 40.00$ is released at $\$ 10.00$ in case of injury, death or damage. Now if this shipment moves wholly within the state of Nebraska this release is not good. However, if the hog is sent from Nebraska into Iowa, then the release holds and the shipper can recover but the released valuation-\$10.00. The shipper will keep in mind, then, that any released value on a livestock chipment moving in this State is not good.

If a special market is desired it should be so stated in the contract, otherwise the carrier is held to schedule-subject, of course, to the eighteen hour law.

In the event of any damage or injury to stock due to the negligence of a railroad company or its employees the railroad company is liable for such injury irregardless of any provision in the contract to the contrary.

A carrier is liable for damages, losses, injury or the escape of stock by reason of defective yards or equipment.

As stated before the railroad company is liable for defective cars furnished for transportation of stock-the equipment must be safe, clean and any provision in the contract to the contrary is void.

A railroad company is liable for damages by fire in straw and hay used for feed while on the premises of the carrier or the escape of the stock from the cars.

A carrier is liable for misconduct of employees, laborers or others whom them employ to load unload or handle live stock, while in the performance of their dutie's.

A carrier is not liable for damages caused by the elements, except as contributed to by the negligence of the carriers. For example: A carrier would not be liable for hogs suffering from the heat, but it would be were the stock to suffer to a greater extent by the failure of the railroad company to provide a shed so that the animals could get in the shade.

Any provision limiting the time in which a claim is to be presented is void, excep's as provided by statute. For instance: A clause in a contract stipulation that the shipper loses his rights to file a claim after the expiration of thirty days, is utterly void and of no effect.

Any provision exempting the carrier from liability in case of injury to the person or persons in charge of livestock is void and of no force.

The shipper should insist on having a duplicate original of his 
contract (other than the one given him which carries his transportation permit) for his information and file.

It has also been held that in the event of a shipper agreeing to personally accompany and take care of the watering of the livestock and is given free transportation for that purpose and supplied with adequate facilities, that he cannot be heard to complain at the end of the trip that the stock did not receive that attention, as the fault is his own. But should the shipper agree to furnish a caretaker and fail to do so and the company being aware of this failure, proceeds under the shipping contract, in that event the railroad company would be liable to the shipper for any loss resulting from such failure to properly care and protect the stock. So is it also true that in case of no agreement being entered into regarding this feature, that the company will be liable for any want of proper care in transit and will be liable for any loss or damage.

Due care must always be exercised by the railroads in transporting a shipper's stock.

The shipper should keep the above points well in mind. Just what motive or reason prompts the incorporation of void provisions and stipulations in a live stock contract-or any other contract-when they certainly must be known to be utterly of no force and effect is an unanswerable question-unless it is the fact that it is an attempt to defeat the shipper of his rights in case of damage. No doubt the shipper, unaware of the voidness of these provisions, when brought face to face with them in event of damage, thinks he has defeated his rights of recovery by signing a contract containing such provis. ions and either withdraws his claim or accepts a small sum far below the amount he is entitled to in settlement-and thinks that the carrier has made him a gift out of the goodness of their hearts. These void provisions are very unfair and their incorporation in a contract, when once they are tested and found void, should be unlaw. ful and should be punishable as a fraud committed upon the damaged shipper.

\section{STOCKMEN'S TRANSPORTATION.}

The shipper is entitled to transportation either for himself, his agent or employee from the point of origin of the shipment to destination and return to the point of origin. If more than six cars are shipped then the shipper is entitled to two men and should two or more cars be shipped in two or more differen's trains or in two separate sections of the same trains, then the shipper would be entitled to have a man with each such train or section in which he has a car of stock.

Should the railroad company refuse transportation to the shipper then it would be liable for all damages sustained, the cost of the shipper's transportation to and returning from point of destination, together with the costs of suit and a reasonable attorney fee. For the second offense the statutes provide a liability of double the damages and cost of transportation both ways, together with the costs of suit and a reasonable attorney fee; and for the third offense, triple damages, triple costs of transportation, together with the cost of suit and a reasonable attorney fee.

\section{CABOOSE.}

The shipper is entitled to ride in a caboose or other suitable car so fitted as to be comfortable and sanitary. It must have a toilet room and water tank with plenty of clean water for the accommodation of the stockmen. If the train has a haul of seventysive miles or more it shall be fitted with comfortable seats such as are used on ordinary passenger cars, adequate heat and ventilation; a toilet room and water tank with plenty of clean water. An additional car of similar character shall be furnished on all stock trains 
for the accommodation of care takers of stock at the first: tra division point reached after it shall appear that fifteen or more ca takers are accompanying or will accompany live stock to be transported on such train prior to its arrival at the next train division point. The Nebraska State Railway Commission will see that these provisions are enforced. Upon arrival at stations where change of cars is necessary the caboose shall be stopped not more than one-half mile from waiting room to be provided by the railroad company and it is the duty of the conductor of the train, or other employee of and designated by said company to show the shipper where the waiting room is located and instruct him to remain there until called for; and at the time or before time of starting of the trains carrying the shipper it shall be the duty of an employee of the railroad company to call at the waiting-room and show him to his caboose or the car in which he is to ride, and this car must not be placed more than onehalf a mile from the waiting room. Should whe above provision be violated the offending company shall be deemed guilty of a misciemeanor and upon conviction fined not less than $\$ 100$, for each day's negligence or refusal to comply therewith.

\section{SPEED OF LIVE STOCK 'SHIPMENTS.}

Livestock must be transported at a rate of speed so that the time consumed in said journey from the initial point of receiving said stock to the point of feeding or destination, shall not exceed one hour for each 18 miles traveled, including the time of stops at stations and other points, except where the initial point is not a division station and on all branch lines not exceeding one hundred and twenty-five miles in length on which branch lines the rate of speed shall be such that not more than one hour shall be consumed in traversing each fourteen miles of distance including the time of stops at stations or other points, from the initial point to the division station or over said branches. The time consumed in picking up and setting out, loading and unloading stock at stations, shall not bo included in the time required.

Upon branch lines not exceeding 125 miles in length, where there is less than six cars of live stock in one consignment, the railroad company may select and designate three days in each week as stock shipping days, and publish and make public the days so desig. nated and after giving ten days notice of the days so selected and designated shall be required upon its branch lines to conform to the schedule above provided, but only upon such days.

For failure to maintain the speed above set forth the railroad? company is liable to the shipper in the sum of ten dollars for each hour for each car over and in excess of such time, as liquidated damages.

This law has been tested through the Supreme Courts of the State and the United States and has been declared good.

\section{THIRTY-SIX HOUR RELEASE.}

The Federal Laws provide that all stock must be unloaded for feed rest and water at the expiration of twenty-eight hours unless the shipper signs a release to the effect that they may be kept or board the cars for a period of not to exceed thirty-six hours. However, no stock can be released for a longer period and at the expiration of thirty-six hours the stock must be unloaded, as above set forth. The time consumed in loading and unloading the stock is not to be counted.

\section{STOCK YARDS.}

Upon arriving at the stock yardis the stock must be handled in an expeditious manner. If it arrives between the hours of 6 o'clock: A. M. and 6 o'clock P. M. it must be unloaded and yarded, when the- 
shipper so requests within two hours after the delivery of the cars to the stock yards company by the connecting railroad, except in case of unavoidable delay or unusual circumstances. For each half hour's delay in handling and unloading the stock beyond the period above set out the stock yard shall forfeit and pay to the shipper the sum of $\$ 5.00$ for each car of livestock so delayed. There' is a further provision to the effect that this money must be paid within twentyfour hours after unloading the stock. and that payment is to be made by mailing a draft or certified check to the shipper, or his agent and in the event of collecting by law suit then an attorney's fee of five dollars per car shall be allowed the shipper-not to exceed $\$ 15.00$ for any one shipment however.

The statutes declare a stock yards company to be a common carrier and under the control of the State Railway Commission and subject to its orders.

It is further provided that a record showing the time of delivery and turning over at the yard of stock to the commission firm, agent, or owner must be kept by every stock yard; that scale facilities sufficient to weigh all livestock without unreasonable delay must be furnished by such stock yards and that adequate yardage, capable of holding and handling all livestock must also be furnished and that no charge for yardage shall be made where yards are not furnished.

An act attempting to further regulate the stock yara's was passed in 1897 but was declared unconstitutional by the Federal Courts and as the chances are that the State Courts would follow the lead of that court, this act will not be included in this book, as it would only vend to confuse.

An erroneous impression is sometimes entertained as to the conduct of business in a stock yards. It is not infrequently that the stock yards, the commission houses and the packers are all considered as being one institution. Three separate and distunct branches of business are found in the conduct of the livestock business.

First. The Stock Yards company does not do a business of buying and selling live stock. Its purpose is to furnish yards for the concentration and handling of live stock and its revenues are derived from pen rental and feed charges.

Second. The live stock commission man is not a buyer and seller of cattle. hogs and sheep, but he is the agent of the producer and handles the stock through the yards for a commission paid by the seller. $\mathrm{He}$ is the medium between the original owner and the packer.

Third. The packer does not speculate in live stock in the yards. He buys the live stock in the yards-takes it to the abattoir (slaughterhouses) and there proceeds by different processes to transform that stock into merchantable packing house products.

However, not all of the live stock arriving in the stock yards goes direct to the packers. The stock yards has another market. Much of the ssock arriving at the yards is unfit for killing. Large numbers of this class of stock-cattle and sheep especially-are bought by farmers to be taken back to the country to be fed out and made ready for the slaughter house and the meat block.

Nowe: Stock brought into this country from foreign countries for exhibition or breeding purposes' and teams of immigrants are admitted free of duty. 


\section{Common Carrier Liability}

We will not take time to dwell here on the points of liability discussed in the previous chapter. It is well, however, to emphasize some further points which properly fall under this heading.

Regarding stock in transit-A railroad company is not liable for damage caused by the elements, (heat, etc); the inherent nature or propensities of the animal, except as contributed to by the negligence of the railroad. The burden of proof is on the carrier to show "jhat the loss resulted from some cause which would have exempted it from liability.

\section{GATES ETC.}

It is the duty of the carrier to keep the gates of openings closed on the right of way, and any damages resulting from the failure or neglect of the railroad to close "ine openings shall make them liable for any clamage caused thereby.

\section{STOCK KILLED ON TRACKS.}

The railroad company is liable for all livestock killed or injured by their agents, employes or engineers or the agents, employes or engines belonging to any other railroad running over and upon their tracks in the event what both sides of their railroad track is not fenced. In the event that the animal is liilled or injured, the owner should make an affidavit to that effect to any officer or agen's of the company, and after thirty days' such notice in the event of the failure of settlement, the owner may bring an action to recover damages and the railroad company shall be liable in double the value of the animal injured killed or destroyed. Should the railroad company not object to the value of the property within ten days af'ser the receipt of such notice, then it shall be considered and taken as the true value. If the railroad company does object they should, within ten days, leave a written notice to that effect at the residence or place of business of the owner of the stock.

\section{ANIMAL INJURED BY RAILROAD.}

It is whe duty of the track walkers and section men of any railroad company on whose tracks a domestic animal has been injured to care for the animal at once and to report the facts to the nearest station agent and the station agent must notify the Nebraska Sitate Humane Society.

If the animal is injured by a train then the conductor must report the fact to the agent as the first regularly scheduled stop and the agent shall notify the section boss or other men in charge of the section on which the animal is injured and shey shall take care of the animal-the station agent also reporting the facts to the Nebraska State Humane Society.

Should such animal be maimed beyond hope of recovery, then it is the duty of the above mentioned persons to forthwith kill such animal.

In the event that the animal is not killed then the agen shall give notice as quickly as possible of the condition of the animal to the owner or his agent, and upon receipt of such notice the owner of his agent shall have the animal properly cared for. But when immediate notice to the owner is not possible, then the station agent mus's have the injured animal properly cared for without delay.

It is expressly provided that any reports given as above set forth shall not be held to be an admission of liability or responsibility on the part of the company for the injury of the animal nor shall it be considered a waiver or relinquishmen's by the owner of any right or claim to damages from said company. 
The penalty for violation of the above provisions is a fine of from five to one hundred dollars.

\section{LIABILITY FOR DELIVERY OF FREIGHT.}

The law states that any railroad company receiving freight for transportation shall be entitled to whe same rights and be subject to the same liabilities as common carriers. And that whenever two or more railroads are connected together, the company owning either of said roads rcceiving, freight to be transported to any place on the line of either of the roads so connected shall be liable as common carriers for the delivery of such freight to the consignee of said freight, in the same order in which such freight was shipped.

\section{ASSENT BY OPPOSITE PARTY OF LIMIT OF LIABILITY.}

No notice, either express or implied, shall be held to limit the liabilities of any railroad company as common carriers, unless they shall make it appear that such limitation was actually brought to the knowledge of the opposite party and assented to by him, or them, in express verms, before such limitation shall take effect.

\section{Freight Rates}

Freight rates are a scientific study in themselves and it is wholly impracticable to either incorporate them bodily in this volume, as they are constantly subjecy to change, nor is it practicable to give the rules governing their making. Thousands of experts are daily at work revising and correcting the rates applicable to the various commodities that are constanily moving. However, the tariffs are kept on file at the various stations of the different railroads and are for public reference. The shipper can verify any rate quoted him by a local agent by reference to these tariffs. However this Association will gladly furnish, gratis, the current rate effective between any points.

Assuming a car mixed with cattle and hogs to originate at Benton, Nebraska, (a point eight miles east of Columbus) and destined to Sarpy, Nebraska, (a point eleven miles west of Omaha, Nebraska) the shipment moving in a standard car and whe toal. distance being 72 miles. How is the rate determined?

Primarily, stock is classed for the purpose of rate applicationand as a car what is made up of mixed stock takes the rate applicable so the highest grade of stock in the car, the rate will be that of hogs.

Applying the distance tariff the rate on hogs would be (assuming the total net weight of the stock to be 25,000$) \$ 35.05$, and this would be the charge for the shipmens under that tariff.

However, in no case shall the rate to any point be greater than the rate to a point further along the line and as the rate from $\mathrm{Co}_{0}$ lumbus omaha on this shipment would be $\$ 32.93$, and as Benton and Sarpy are intermediate points this rate of $\$ 32.93$ would apply.

So it will be seen that the shipper should be so familiar with the various rules and regulations that he can plan and ship his stock in an advantageous manner. These rules and regulations are set out at length in a separate chapter of this book and should be carefully read. 


\section{Shipping Laws}

\section{FURNISH TRANSPORTATION TO SHIPPER OF STOCK.}

That every person, company, or corporation owning, managing or operating a railroad in the state of Nebraska, and engaged in the shipment and transportation of live stock in car loads from one point to another point within the state of Nebraska is hereby required to furnish transportation to the owner, his agent, or employee from the shipping point to the destination of such shipment as named in the contract or bill of lading on the same train with his said live stock and to furnish transportation to the owner. his agent or employee, back to the point or place from which the shipment was made without further expense to such owner, his agent or employee, for said transportation in shipments of one or more cars, and shall furnish transportation each way for two men accompanying said subck, in shipments of from six or more cars of live stock in a single train, but if the shipment is made in two or more separate trains or in separate sections of the same train then one such right of transportation shall be given "io such owner, his agent or employee, for each separate train, or for each separate section of the same train in which such shipment is made. Provided, that all railroad companies shall furnish transportation both ways vo the actual owner in charge of one carload of either horses or mixed stock. Provided further, that no one but the actual owner shall be given transportation with shipmenis of hogs.

\section{LIABLE FOR DAMAGE FOR VIOLATION DF ACT.}

Any common carrier of live stock in carload lots refusing to comply with or violating the requirements of the foregoing section shall be liable to the shipper of such live stock for all damages sustained by reason of such refusal or violation, including the cost of transportation of the shipper, his agent or employee to and from the destination of such live stock, together with the costs of suit and a reasonable aiftorney fee to be taxed by the court trying the said cause, and for the second refusal to comply with or a violation of the said requirements, the common carrier shall be liable to the shipper as a penalty for such violation in a sum double the damages sustained and double the cost of such iransportation together with the costs and reasonable attorney's fee to be taxed by the court trying - the cause, and for a third refusal to comply with or a violation of said requirements as a penalty for such violation in triple damages, sriple costs of transportation, besides the cost including a reasonable aitorney's fee to be taxed by the court trying the cause.

\section{FURNISH CABOOSE FOR USE OF SHIPPER.}

Every individual, company or corporation owning, managing, or operating, or who may hereafter own, manage or operate any railroad or part of a railroad in this state, which carries passengers, or whose duty it is to transport live stock as a common carrier, is hereby required to furnish for the use of such passenger. shipper of livestock. or to those having the right to accompany the same, a caboose or other sui"vable car for the comfortable transportation of such passenger or shippers of live stock and which caboose or car on all such trains shall be furnished with a toilet room and water tank with clean water for the accomodation of such passenger or shippers of live stock. Provided, that on and afier the passage and approval of this act, all trains having a haul of seventy-five miles or more shall be furnished with a car fitted with comfortable seats such as are used in an ordinary passenger car; provided with adequate hea" and ventilation; a toilet room and water tank with plenty of clean water. Provided further, that an additional car of similar character 
shall be furnished on all such stock trains for the accomodation of caretakers at the first train division point reached aifer it shall appear that fifteen or more caretakers are accompanying or will accompany live stock to be transported on such train prior to its arrival at the next train division point. And in each car or caboose used for the purpose herein provided for, such railroad company shall cause to be printed copies of this act and shall posiv the same in a conspicuous place in such caboose, and it shall be the duty of the railway commissioners to enforce the provisions herein made. It is further provided that when cars or cabooses on which such passengers or shippers are riding shall arrive at sutations where change of cars is necessary it shall be stopped not more than one-half mile from waiting room to be provided by said company. and it shall be the duty of the conductor of said train, or other employee of and designated by said company, to show said passengers where waiting room is located and instruct them to remain there until called for; and at the time or before the time of starting of vhe trains carrying said passengers it shall Be the duty of an employee of the railroad company, to call at said waiting room and show such passengers to their caboose or car on which they are sto ride. It is provided further that such car shall be placed within one-half mile of said waiting room.

\section{VIOLATION OF ACT-PENALTY.}

Any common carrier doing business in this stute and failing or refusing to comply with the requirements of the foregoing section shall be deemed guilty of a misdemeanor and upon conviction thereof shall be fined no"s less than $\$ 100$ for each day's negligence or refusal to comply therewith and all moneys so collected as fines shall be paid into the public school funds of the State.

\section{SHIPPING YARDS AND PENS.}

Every railroad company operating in this state shall on .or before January 1st, 1912, build and maintain adequate and safe sheds for the protection of hogs at all shipping yards from which not less than forty cars of hogs are shipped per annum; provided however, that a shipping yards from which not less than forty cars of hogs are shipped per annum the railroad company shall provide ample sheds for shel'sering at least one car of hogs and that the capacity of the shed protection herein provided for shall be increased so as to take care of one additional car of hogs with each additional forty cars of hogs shipped from said station per annum but in no event need the sheds be built is accomodate more than four cars of hogs at any one time. Said sheds shall be constructed in a safe and substantial form.

\section{PENALTY FOR EACH DAY'S NEGLECT.}

Any railroad company failing or neglecting to comply with the provisions of this Act shall be deemed guilsy of a misdemeanor and upon conviction thereof, shall pay a fine of not less than five dollars per day for every day of failure or neglect to provide, at any shipping point along its line, the sheds required by this Act.

\section{RAILROAD COMMISSION CONTROL ENFORCEMENT OF ACT.}

It shall be the du'y of the State Railway Commission to enforce the provisions of this Act, provided however, that upon a proper showing by any railroad company that it cannot comply with the terms of this act by January 1sv, 1912, the State Railway Commission is hereby empowered to grant such extension of time as it may deem reasonable and just. 


\section{PRIVATE SHIPPING PENS ON RIGHT OF WAY.}

Any shipper or association of shippers of livestock within this state may apply to "sine local agent at any station of any railroad company for use of space upon the right of way of such railroad convenient to the shipping pens of such railroad at said station or at any siding in said county. Said application shall be in writing and shall set for's the probable amount of livestock to be shipped by the applicants from said station or siding during the next twelve months and the space desired by said applicants on which to erect shed's for temporary shelter of livestock awaiting shipmen's. The application shall specifically set forth the plans for said sheds and their position with referenc to the railroad company's tracks and shipping pens, together with any fac'ss or arguments why said application should be granted.

\section{PETITION TO COMMISSION FOR RIGHT TO ERECT PENS.}

In case no agreement is reached between said applicants and the railroad company for use of said right of way for such purposes the applicants shall present their petition to the state railway commission reciting the facts set forth in their application and praying the state railway commission for relief in the premises.

\section{HEARING AND INVESTIGATION.}

It shall be the duty of the state railway commission to set a time for hearing upon said petition, to make a thorough investrigation of facts and conditions set forth and issue thereupon such order for relief as may be reasonable and within the power of such commission. Provided however, that no railroad company shall be liable to the owner or owners of any sheds or sisuctures erected upon the right of way under the provisions of this act, for the destruction of same or damage thereto or destruction or damage to animals contained therein, by any cause wha'tsoever.

\section{PENALTY.}

Any railroad company failing to comply with said order within thirty_days thereafter shall be fined in any sum not exceeding one hundrod dollirs and be liable, in addition, for any loss sustained by livestock shippers because of such failure.

\section{SPEED OF LIVESTOCK SHIPMENTS.}

It is hereby declared and made the duty of each Corporation, individual or association of indiviJuals, operating any Railroad as a Public Carrier of freight in the State of Nebraska, in transporting live stock from one point to another in said state in car-load lots in consideration of the freight charges paid therefor, to run their train conveying the same at a rate of speed so that the time consumed in said journey from the initial point of receiving said stock to whe point of feeding or destination, shall not exceed one hour for each eighteen miles traveled including the time of stops at staivions or other points provided in cases where the initial point is not a division station and on all branch lines not exceeding one hundred and twenty-five miles in lengin, the rate of speed shall be such that not more than one hour shall be consumed in traversing each fourteen miles of the distance including the time at stops at stations or other points, from the initial poin's to first division station or over said branches. The time consumed in picking up and setting out, loading or unloading stock at stavions, shall not be included in the time required, as provided in this schedule. Provided further, that upon branch lines not exceeding 125 miles in length live stock of less than six cars in one consignment, each railroad company in this state may select and designate three days in each week as stock shipping days, and 
publish and make public the days so designaved and after giving ten days notice of the days so selected and designated, shall be required upon its branch lines to conform to the schedule in this act provided, only upon said days so designated as stock shipping days.

ANNO. (A common carrier of live stock is generally an insurer of their safe delivery. The delivery of stock to a carrier in good order and their arrival at their destination in bad order, makes a prima facie case against the carrier. A cause for unavoidable delay affords no excuse for a failure to exercise that degree of care required of a common carrier in the transportation of stock. The carrier cannot relieve itself of responsibility by a written contract whereby the shipper agreed to accompany the stock, when the carrier with knowledge of the failure on the part of the shipper to accompany the stock proceeds under the shipping contract.)

\section{PENALTY FOR VIOLATION OF ACT.}

Any individual corporation, or association of individuals, viola:ing any provisions of this act shall pay to the owner of such livestock, the sum of ten dollars for each hour for each car it extends or prolongs the time of transportavion beyond the period herein limited as liquidated damages to be recovered in an ordinary action, as other debts are recovered.

\section{RAILROAD CARS FOR TRANSPORTING HOGS AND SHEEP TO BE CLEANED.}

That from and after the first day of June, A. D. 1877, it shall be unlawful for any railroad company operausing its road in this state to bring or cause to be brought into this state from an adjoining state any empty car used for transporting hogs or sheep, or any empty combination car used for carrying grain and stock that has any filth of any kind whatever in the same; but the said railroad company shall before it allows said car or cars to pass into this state, cause the same to be thoroughly cleaned and cleansed. Any person or persons or corporavion violating any of the above provisions, and on conviction thereof, shall be fined in any sum not to exceed one hundred dollars.

\section{SHEEP AND HOG CARS MUST BE CLEANED.}

No railroad company is permitted to bring or cause to be brought into this state any empty car used for transportsing hogs and sheep or any empty combination car used for carrying grain and stock that has any filth of any kind whatever in it. The car must be thoroughly cleaned and cleansed before being brough's in. Penalty for violation, a fine not to exceed one hundired dollars.

\section{PETITION FOR INSPECTOR OF STOCK TO BE SHIPPED.}

If your shipment is to an open market-South Omaha, Sioux City, Chicago, Kansas City, South St. Joseph-then the following laws are immaterial.

Whenever in any county in this State one hundred or more residents of such county who are each owners of cattle and horses shall petivion the board of county commissioners or board of supervisors in counties under township organization, of their county for whe appointment of an inspector of stock shipments from said county it shall be the duty of the said board to fix a time for hearing said petition and to give notice thereof by publicavion in a newspaper published in such county for two weeks immediately preceding the time of hearing and if upon said hearing, upon due proof, the board shall find "shat such petition is signed by one hundred or more residents of such county who are the owner of cattle and horses, it shall then be the duty of the board to appoint some suitable, competent person as such inspector for said county. 


\section{BOND AND OATH OF INSPECTOR.}

Such person shall be a resident of the county for which he shall be appointed. He shall before entering upon the duties of his office take the oath prescribed for other county officers in Section 9400, Cobbey's Annotated Suratutes for 1907, and shall give a bond in the sum of one thousand dollars $(\$ 1000.00)$ payable to the county in which he shall be appointed, with either surety company or personal securities thereon, to be approved by the county clerk of such county, which bond shall be filed and recorded in the office of such clerk.

\section{TERM OR OFFICE-DEPUTIES.}

The inspector appointed in any county under this Act shall hold his office for two years from the daive of his appointment, and until his successor is duly appointed and qualified. He may appoint deputy inspectors to assist in the work when needed and such deputies when engaged in their duties shall have the same powers and the same pay as the chief inspec"sor.

\section{COUNTY BOARD FILL VACANCY-ABOLISHMENT OF OFFICE.}

The board of county commissioners or board of supervisors in counties under township organization of each county where the office of inspector of stock shipments exists shall fill by appointment all vacancies occurring in said office, or about to occur by reason of the expiraivion of the term of any incumbent. Provided That if a majority of the owners of cattle and horses in any such county petition the board of county commissioners thereof or board of supervisors in counties under township organization to aboish said office, such board may in its discrevion abolish the same, to take effect upon the expiration of the term of the then incumbent.

\section{FEES FOR INSPECTION.}

The chief inspector of stock shipments shall receive for his services for inspection of stock shipments, the sum of 4 cents per head for cattle inspected and ten cents per head for horses inspected. To be paid by the owner of the stock inspected.

\section{DUTY OF SHIPPER-FRAUDULENT SHIPMENT-PENALTY.}

It shall be the duty of every owner or shipper of horses and cattle in said county intending to ship horses or cattle out of said counify to notify the inspector of stock shipments before the shipment thereof in ample time to enable said inspector to properly inspect the same. Said notice shall be in writing and must state the time and place of proposed shipmen"' and the probable number to be shipped. Any person or persons, firm, railroad or other company or corporation who shall ship any cattle or horses out of said county without first having had the same inspected as in this Act provided and withou's having a proper certificate of such inspection or who shall make, forge or use any false or fraudulent certificate of inspection shall be deemed guilty of a misdemeanor and shall upon conviction thereof be punished by a fine of not more than five hundred dollars $(\$ 500.00)$ or by imprisonment in the county jail not to exceed one year, or by boin fine and imprisonment in the discretion of the court.

\section{DUTY OF INSPECTOR-CERTIFICATE.}

It shall be the duty of the inspector of stock shipments either in person or by deputy, whenever he shall have knowledge in any way of the intended shipment of horses or cat'sle out of his county, to immediately repair to the proposed place of shipment and make a careful inspection of said horses or cattle. He shall, after having 
inspected the same make ou 0 a certificate of inspection, which certificate shall be in writing and shall be executed in triplicate and shall contain the name of the owner or shipper of said stock, the number and kind, the place from where shipped and the time thereof, the proposed destination of the stock, together with all marks and brands thereon and shall be signed by the inspector, the original of which he shall retain in his office. A copy of which shall be delivered wo the agent of the railroad company and from the shipment originated, before the shipment is made, and a copy of which shall be immediately delivered to the owner or shipper of said stock and when properly made out and signed as hereinbefore provided, shall entitle the owner or shipper of said stock to remove the same from the county and shall entitle any railroad company to receive the same for shipment out of the county.

\section{FEES PAID BY OWNER BELONG TO INSPECTOR.}

The owner or shipper of any horses or cattle shipped under the provisions of inis Act shall pay the inspector an inspection fee of four cents per headl for all cattle not billed to an open market, and ten cents per head for all horses so inspected at the time of inspection, and prior to the issuance of the certificate of inspection. All such fees shall be retained by the inspector or deputy inspector: for his or their service.

\section{OPEN MARKET DEFINED.}

Provided, that Chicago, Kansas City, South St. Joseph, South Omaha and Sioux Cility shall be classed as open markets so long as they maintain brand inspection under the supervision of the Nebraska Stock Growers Association.

\section{BRAND INSPECTION NOT REQUIRED ON OPEN MARKET.}

Provided, that where cattle are shipped to an open market no brand inspection shall be required as point of loading, and further provided that where cattle are billed to an open market, it shall be a misdemeanor and violation of this Law for the railroad company to allow the owner, shipper or party in charge to change billing without first having secured from the inspector of the county from which the cattle originated, or from "she Nebraska Stock Growers Association inspector of South Omaha a certificate of brands.

\section{LIABILITY AS COMMON CARRIERS FOR DELIVERY OF FREIGHT.}

Any railroad company receiving freight for transportation, shall be entitled to the same rights and be subject to the same liabilities as common carriers. And whenever two or more railroads are connected together, the company owning either of said roads receiving freight to be transported to any place on the line of either of the roads so connected shall be liable as common carriers for the delivery of such freight to the consignee of said freight in the same order in which such freight was shipped.

\section{COMPANY LIABLE FOR STOCK INJURED.}

Any railroad company hereafter running or operating its road in this state, and failing to fence on both sides thereof against all livestock running at large at all points, shall be absolutely liable to the owner of any live stock injured, killed. or destroyed by their agents, employes, or engineers, or by the agents employes, or engines belonging to any other railroad company running over and upon such road, or there being; Provided. Thas in case the railroad company, liable under the provisions of this section shall neglect or refuse to pay the value of any property so injured or destroyed, after thirty days' notice in writing given, accompanied by an affidavi's of 
the injury or destruction of said property to any officer of the company, or any station agent, or tickes agent, employed in the management of its business in the county where the injury complained of shall have been committed, such railroad company their agents, and employes, shall, in an acivion brought to recover damages therefor be held, and they are hereby declared to be liable to pay double the value of ine propertv so injured, killed, or destroyed as aforesaid; Provides further, That if the railroad company does not object to the value of the property so injured, or destroyed, as set forth in the notice aforesaid within ten days, it shall be considered and taken as the true value, but if the said company are dissatisfied with the value as set for'sh in said notice, they shall, within ten days, leave a written notice to that effect at the residence or place of business of the owner of the stock so injured or desiroyed, and the value shall then be ascertained and cietermined in accordance with the provisions of Section 5 of the general herd law. (3132).

\section{INJURED ANIMAL REPORTED.}

Whenever any horse, cow or other domestic animal is injured by a train or otherwise on the righ's of way of any railroad company it shall be the duty of trackwalkers and section men of said company to care for said animal at once and report the facts to the nearesi station agent, who shall notify the Nebraska State Humane Society; in case such animal shall be injured by a Jrain it shall be the duty of the conductor thereof, upon arriving at the first station at which such train is due to stop, to notify the age's of such station of the fact and such agent shall at once cause to be notified the section boss or other men having charge of the secition upon which such animal is injured, whose duty it shall be to at once care for such animal, and said station agent so reported to shall notify the Nebraska State Humane Society. If any such animal is maimed beyond hope of recovery it shall be the duty of said persons to forthwith kill such animal. When such animal is not killed, it shall be the duty of the agent to give immediate notice when possible, of the condition of such animal to the owner or his agent, whose duty it shall be forthwiin. upon receipt of notice to have such animal properlv cared for. When immediate notice to the owner is not possible, it shall be the duty of the station agent to have the injured animal properly cared for without delay.

\section{REPORT NOT AN ADMISSION UF LIABILITY.}

No such act of said railroad company, its employees or agents, or the owner of such injured animal shall be held to be an admission of liability or responsibility on the part of the said company for the injury of the said animal nor a waiver or relinquishment by said owner of any right or claim to damages from said company.

\section{PENALTY.}

Any person who shall violate any provision of this act shall upon conviction be fired in any sum not less than five or more than one hundred dollars.

\section{WHO DEEMED A STOCK GROWER-CATTLE DROVER.}

Every person who shall keep neait cattle, horses, mules, sheep, or goats, for their growth or increase within the state, shall be deemed a stock grower. Any person who shall drive or bring neat cattle into or through this state, shall be deemed a cattle drover.

\section{ROUNDING UP CATTLE-TIME.}

That in any portion of the state where it is customary round up cattle for the purpose of branding, marketing, driving, or selling cattle, it shall be unlawful for any person or persons to commence said roun "- -up between "ine first day of December and the fifteenth 
day of May of each year, and anyone violating the provisions of this act shall forfeit and pay a fine of not less than five hundred dollars, to be recovered before any court having jurisdiction, upon the information and complaint of any person.

\section{PENALTY FOR DRIVING OFF CATTLE OF ANOTHER.}

That any catisle drover, or his employee, who shall drive off any neat cattle, horses, mules, or sheep belonging to another intentionally or through neglect, shall on conviction thereof, by any court of competent jurisdicivion, be fined in any sum not more than one hundred $(\$ 100)$ dollars for each and every head of cattle, horses, muies, or sheep so driven off.

\section{BRAND PRIMA FACIE EVIDENCE OF OWNERSHIP.}

In any indictment or complaint under this act, the description of any kind or class of neat cattle shall be deemed sufficient if described as cat'sle; and for the purpose of this act the proof of brand shall be deemed to be a prima facie evidence of ownership of such stock.

\section{PENALTY FOR ALLOWING MALE ANIMAL TO RUN} AT LARGE-DAMAGES.

That the owner of any stallion, jack, bull, buck or boar shall restrain the same, and any person may take possession of any such animal running at large in the county in which such person resides, or in which he occupies or uses real estate, and he shall give notice thereof "to the sheriff or any constable in the county in which such animal is taken, who shall give notice to the owner of such animal if known to him, by delivering a written notice to said owner, or leaving same a" his usual place of abode, giving a description of the animal so taken. If such owner does not appear within ten (10) days after such notice to claim his property and pay costs and damages if any, then the said sheriff or constable shall sell the animal so taken at public aucition to the highest bidder for case, having given twenty days notice of the time and place of sale with a description of the property, by publishing the same in a newspaper of general circulation in the countr, or if there be no such paner by posting such notice in three public places in the township or precinct in which such animal was found at large, out of the proceeds of such sale he shall pay all costs and any damages done by such animal, to be ascertained and determined by him, and the said sheriff or constable shall pay the remainder if any, into the county treasury for the use of the county. If legal proof be made to the county commissioners by the owner of said animal of a right thereto at any time within one year of the sale, the county commissioners shall order the proper amount to be paid to the owner by "sheir warrant drawn for that purpose. If the owner, or any person for him, on or before the day of sale shall pay the costs thus far made and all damages, to be determined by the sheriff or constable if the parties cannot agree', and made satisfactory proof of his ownership the sheriff or constable shall release the animal to him. Provided, that this act shall not be consirrued as a bar to any suit for damages sustained and not covered by the proceeds of the sale as hereinbefore provided.

Title is not comprehensive enough to authorize giving damages for castration of animals. Ives $\mathrm{v}$ Norris, 13 Neb. 253.

\section{DUTY OF DROVER TO PROTECT SETTLER FROM STOCK-DAMAGES.}

Any person owning or having charge of any drove of cattle, horses, or sheep numbering one (1) head or more than that number in any: such drove of catile, horses or sheep, and shall drive the same into or through any county of Nebraska of which the owner is 
not a resident, or land owner, or stock grower, and when the land. in said county is already occupied by settlers on ranches, it shall be the duty of said owner or person in charge of said horses, cattle, or sheep 40 prevent the same from mixing with the cattle, horses, or sheep belonging to actual settlers, and also to prevent said drove of cattle from trespassing on such land as may be the property of the actual settler, or may be held by him under a homestead, pre-emption, or a leasehold right and used by him for the grazing of animals, growing hay or timber, or other agricultural purposes, or doing injury to the ditches madie for irrigation of crops. If any owner or owners, or persons in charge of any such drove of cattle, horses, or sheep shall wilfully, carelessly, or negligently injure any resident within the state by driving said drove of cattle, horses, or sheep from the public highways and herding the same on the lands occupied and improved by settlers in possession of the same, it shall constitute a misdemeanor and shall be punished by a fine of not less than twenty $(\$ 20)$ dollars and not more than one hundred $(\$ 100)$ dollars, at the discretion of the court, and render the owner or owners, or person in charge of the drove of castle, horses, or sheep liable for such damages as may be done to the property of said settle:-

\section{DAMAGES FOR DRIVING OFF STOCK OF ANOTHER.}

When the stock of any person shall be driven off its range with' Nebraska against his will by the drovers of any drove, and the san shall be found among such drove, every person engaged as a drover. oI said drove shall be liable for damages to the party injured to the amount of the full value of the animal for each head so driven off, together with all costs accruing in the trial of said cause, and said herd of stock shall be liable for the same, or a sufficient number to cover all damages and costs.

\section{PENALTY FOR FAILURE TO SEPARATE CATTLE MIXED WITH DROVE.}

When the stock of any resident of the staive of Nebraska shall either mix with any drove of any animals it shall be the duty of the drover or drovers, or person in charge of such drove, to cus out and separate such stock from said droves immediately. Every: person, either owner or driver, or otherwise connected with said drove, who shall neglect to comply with the provisions of this section shall be fined in any sum now exceeding one thousand $(\$ 1,000)$ dollars. 


\section{Herding, Estrays, Etc.}

\section{SKIN OF ANIMAL FOUND DEAD REMOVED BY OWNER.}

It shall be unlawful for any person other than the owner or his agent or employee, to skin or remove from the carcass the skin, hide, or pelt of any neat catitle or sheep found dead, except when such stock is killed by railroad trains, when the employees of such railroads may remove the hides from stock so killed.

\section{REWARD FOR VIOLATORS OF ACT.}

The county commissioners of the several counties may offer and pay rewards for the detection of those violating this act.

\section{STOCK LIABLE FOR DAMAGES TO CULTIVATED LANDS}

That the owners of catile, horses, mules, swine and sheep in this state, shall hereafter be liable for all damages done by such stock upon the cultivated lands in this state as herein provided by this act.

(a) That all damage to property so committed by such stock running at large, shall be paid by the owners of said stock; and the person whose property is so damaged thereby, may have a lien upon such trespassing animals, for the full amount of damages and costs, and may enforce the collection of the same by the proper civil action.

\section{TAKER-UP NOTIFY OWNER OF DAMAGES CLAIMED- FORM OF NOTICE.}

(b.) That when any stock shal? be found upon the cultivated lands of another, it shall be lawful for the owner, or person in possession of said lands, to impound said stock and if the owner of said stock can be found, and is known to the taker-up, it shall be the duty of said taker-up to notify said owner by leaving a written notice at his usual place of residence, with some member of his family over the age of fourteen, or in the absence of such person, by posting a copy of such notice on the door of said residence, of the taking up of said stock describing it, and stating the amount of damages claimed; also, the name of his arbitrator, and requiring him wi'hin forty-eight hours after receiving said notice to take the said property away, after making full payment of all damages and costs to the satisfaction of said taker-up of trespassing animal. Said notice may be in the following form: Mr. hereby notified that on this day of. ; you are 19 ............, your stock of which I now have in my possession (here describe the animal or animals) - did trespass upon my land and damage the same to the amount of ........................ You are required to pay the above charges wi'thin forty-eight hours from the delivery of this notice, or the aforesaid stock will be sold as provided by law. I have appointed Mr. .......................to acts as arbitrator should you not feel satisfied with the amount of damages claimed in the within notice. Provided, That no claim for damages shall be maintained by the saker-up without the notice contemplated in this section shall have been given, when the owner is known by the taker-up of such stock.

\section{OWNER FAILING TO PAY OR ARBITRATE-STOCK SOLD.}

(c.) If the owner of said stock shall refuse, within forty-eight hours after having been notified in writing, to pay said damages claimed, or appoint an arbitrator to represent his interests. said animal or animals shall be sold upon execution as required by law, when said amount of damages and costs have been filed with any justice of the peace of the county within which said damages may have been sustained. 


\section{You are Always Right When You Give Your Live Stock Business}

to a well established reliable, responsible and efficient Commission Firm. You will find all of these, and even more than you expect with

\section{Byers Bros. \& Co. South Omaha}

We have houses at Chicago, Kansas City \& St. Joe

Millard Hotel

Auto \& Taxicab Livery

Douglas 4966

Stand 13th and Douglas

Stockman's Trade a Specialty 


\section{POLLACK'S}

Family Liquor Store

Imported and Domestic Light Wines a Specialty.

Rare Whiskies and Rare Brandies for Rare Occasions.

Willow Springs Beer-

"Stars and Stripes."

\section{Henry N. Pollack}

Phone Doug. 7162 Cor. 15th \& Cap. Ave.

\section{Stars and Stripes Buffet}

Walter Fisher, Proprietor

Selling the Celebrated

Wedding Bouquet

... Dealers in ...

Whisky, Wines and Beer, Cigars and Tobacco

Hot Lunch in Connection

Stockmen's Trade a Specialty 


\section{ARBITRATORS APPOINTED WHERE DISAGREEMENT AS TO DAMAGES.}

(d.) In case the parties interested canno's agree as to the amount of damages and costs sustained, each party may choose a man, and in case the two men chosen cannot agree, they shall choose a third man, who, after being duly sworn for the purpose herein named, the three shall proceed to assess the damages, possessing for that purpose the general power of arbitrators.

AWARD OF ARBITRATORS ACTS AS A JUDGMENT-LIEN.

(e.) The said arbitrator or arbitrators shall make an award in writing, which, if not paid within five days after the award has been made, may be filed with any justice of the peace in the same county, and shall operate as a judgment, which judgment shall be a lien upon the stock so taken up, and execution may issue upon said stock for the collection of said damages and costs, as in other cases: Provided, That either party may have an appeal from said judgment, as in other cases before justices of the peace. Said arbitrators shall be allowed two dollars each for their services: Provided, further, That if, before the "Urial by said arbitrator or arbitrators, court, or jury, or shall affirm (offer in) writing, to confess judgment for the same, and if, notwithstanding the said injured person refusing said offer, cause the trial to proceed, he shall pay costs'and necessarily the damage awarded.

\section{WHEN STOCK TAKEN UP AS ESTRAY.}

(f.) In case the owner of said stock is not known or found in said county, as herein set forth, the taker-up of said stock so trespassing upon cultivated lands, shall, in such cases, proceed as provided by law regulating estrays, and the stock shall be held liable for all damages and costs.

\section{CULTIVATED LANDS DEFINED.}

(g.) Cultivated lands within the meaning of this act shall include all forest trees, fruit trees and hedge-rows planted on said lands, also all lands surrounded by a plowed strip not less than one rod in width, which sirrip shall be plowed at least once a year.

\section{REMEDY CUMULATIVE.}

Nothing herein contained shall be so construed as to prevent any owner of cultivated lands, or fruit or forst trees from maintaining an action for all damages caused by stock which has escaped or been driven away from the premises of the party ihus damaged, against the owner of the stock causing such damage.

\section{SHEEP AND SWINE NOT TO RUN AT LARGE.}

That from and after the first day of March, A. D. 1875, sheep and swine shall be restrained from running at large in the state of Nebraska.

\section{SUBJECT TO LIEN FOR DAMAGE DONE.}

That all damages io property committed by such stock so running at large, shall be paid by the owner of said stock, and the person whose property is damaged thereby, may have a lien upon said trespassing animal for the full amount of damages and costs, and enforce and collect the same by the proper civil action.

\section{STOCK NOT TO RUN AT LARGE AT NIGHT.}

No cattle, horses, mules, swine, or sheep, shall run at large during the night time; between sunset and sunrise in the state of $\mathrm{Ne}$ braska, and the owner or owners of any such animals shall be liable in an action for damages done during such night time. 


\section{DAMAGES-HOW ASSESSED AND COLLECTED.}

Damages shall be assessed and collected by notice given to owners, and arbitraturs chosen, stock sold, judgment awarded; and in case of estrays, as provided in sections $2,3,4,5,6,7$ and 8 of this article. (a to g.).

\section{OWNER OF STOCK LIABLE FOR DAMAGE ON ENCLOSED LAND.}

If any domestic animal break into any enclosure the person injured thereby shall recover the amount of damage done, if it shall appear that the fence through which said animal broke was a lawful fence.

\section{EFFECT OF TENDER MADE BY OWNER OF STOCK.}

If before trial the owner of such trespassing animals shall have tendered to the person injured an amount in lieu of damage and costs which may have accrued, which shall equal the amount of damage afterward awarded by the court or by the jury, or shall offer in writing to confess judgment for the same, and if, notwithstanding, the said injured persons refusing saidl offer, cause the trial to proceed he shall pay costs, and recover only the damage awarded.

\section{LIABILITY OF PERSON GROWING CROP ON} UNINCLOSED LAND.

If any person sow any grain, or plant any crop, without inclosing the same with a sufficient fence, as above provided, he shall be liable for all damages that any person or persons may sustain in consequence of such neglect to enclose the same.

\section{LIMITATION AS TO EXTENT OF LAW.}

This subdivision shall not extend to or in anywise affect any county in this state in which horses, mules, cattle, sheep, or swine are restrained from running at large by legislative enactment.

\section{WHEN AND HOW STOCK TAKEN UP.}

It shall be lawful for any person holding land in this state, by deed, title, bond, or lease for one or more years, and being in possession thereof to take up any estray horse, mule or ass, neat cattle, sheep, or swine, found within his enclosed premises at any season of the year; and any estray found around the premises of any lessee or freeholder between the twentieth day of October and the first day of April, may be taken up by such lessee or freeholder; and any horse, mule, or ass, with any portion of harness attached to them, and any oxen, with yole, that are believed to have strayed away from their owners may be taken up by any person a's any time.

\section{DESCRIPTION RECORDED AND PUBLISHED.}

It shall be the duty of any person taking up an estray animal or animals to send a description of the same to a justice of the peace in the precinct where the said estray was taken up, within fortyeight hours thereafter, and said justice of the peace shall record the same in a book kept by him for that purpose for which he shall receive the sum of twenty-five cents. If said estray or estrays shall not be claimed by the owner thereof within ten days thereafter, a description of the same shall be sent to the county clerk by the par'y taking up said estray, who shall immediately record the same in a book kept by him for that purpose, for which he shall receive the sum of twenty-five cents. The person taking up the estray shall, within twenty days thereafter, procure the publication of the description of such animal or animals in any newspaper published within the county. 


\section{PUBLISHED FIVE WEEKS FOR THREE DOLLARS.}

The proprietor of said newspaper shall publish said description for at least five consecutive weeks, and shall receive therefor the sum of three dollars: Provided, That if two or more estrays of the same species shall be taken up by the same person at the same time, they shall be included in the same publication; and in such case the aforesaid publisher shall receive no more than for one of such species, except, where the number so described shall exceed three, he shall receive one dollar for each estray beyond that number included in such publication.

\section{OWNER MAY RECLAIM BEFORE SALE.}

The owner of an estray may, at any time previous to its sale, reclaim the same on proving said property by oath or otherwise, and paying for the advertisement, and a reasonable compensation for any other necessary expenses incurred by the person taking up said estray. strictly.

Ed. note: To tax fees under this statute it must be followed

\section{ARBITRATION IN CASE OF DISAGREEMENT.}

In case the parties cannot agree upon the amount of the expenses incurred, they may each choose a disinterested person to act as arbitrators, and the two chosen may choose a third. The decision of the arbitrators shall be final.

\section{WHEN ESTRAYS BECOME PROPERTY OF TAKER-UP.}

When an estray, if it be a sheep, swine, or calf under the age of one year, has not been reclaimed within six months after the advertising the same, it shall become the property of the person daking it up without further proceedings. If the estray be a horse, mule, ass, bull, cow or steer, over the age of two years, it must be reclaimed within six months from the time it was first advertised. If the estray is an animal over the age of one year and not over the age of two years, it must be reclaimed within six mon'shs from the time it was first advertised. If any estray included in the last two named classes shall not be reclaimed within the time specified respectively, the person taking up the estray shall notify a justice of the peace of the county wherein said elstray was taken up, who shall appoint two disinterested persons, and administer to them an oath or affirmation fo faithfully and truly appraise the same at its true value and make due return thereof, in writing, to said justice of the peace, who shall appoint a day of sale, and cause notice of the time and place of sale to be published as least five weeks consecutively before the day of sale in a newspaper printed in said county, and by posting up written or printed notices in three public places in "ine precinct where the estray is to be sold; and in case there is no newspaper printed in said county, there shall be three additional written or printed notices posted up at the county seas of said county, and on the day appointed said estray shall be sold by said justice to the highest bidder in cash; and the proceeds thereof after deducting the costs of the proceedings and the expenses of keeping said estray, shall be paid to the county treasurer within ten days after the sale', subject to the order of the owner, provided the owner of said estray shall establish his ownership to the same, to the satisfaction of the county treasurer of said county within one year from the day of sale; and if said balance is not so claimed, within the sime so specified, it shall be placed by said treasurer to the credit of the general school fund of said county. 
The lace of sale shall be be at the residence of the person taking wp the estray.

MUST BRING TWO-THIRDS OF APPRAISED VALUE.

When an estray is sold, it must bring at least two-thirds of the appraised value. In case it does not the animal shall be re-appraised, and again offered for sale one week after the day appointed for the first sale, and no advertisement whall be necessary for the second sale.

\section{WHEN TAKER-UP BECOMES OWNER WITHOUT SALE.}

When the appraisers think that the animal will not bring more than enough to defray the necessary expenses of the sale and advertisement thereof, said sale shall be dispensed with, and the person who took up the animal shall, on the payment of expenses, be the owner thereof.

\section{PROCEEDS QF SALE.}

The money received from the sale of an estray shall go into the county school fund, all expenses firs's being paid.

\section{PENALTY FOR VIOLATION OF PRECEDING SECTION.}

Any person violating section ten (preceding section) of this chapter shall be liable to a fine of not less tran twenty dollars nor more than two hundred dollars.

\section{ESTIMATE VALUE OF TROUBLE AND EXPENSE}

\section{BY APPRAISERS.}

The appraisers of estrays shall estimate the value of the labor, trouble, and expense of the person in taking up and keeping an estray-taking into consideration the services rendered by the anmal.

\section{TAKER-UP PAY FEES AND CHARGES.}

The advertisement, the appraisement, and the services of the justice of the peace shall be paid by the person taking up the estray, and he shall receive the same, with fifty per cent additional, from the proceeds of the sale of the estray.

Editor's Note: Cne taking up an estray cannot prevent owner from recovering property by refusing to accept compensation for expenses or to submit his claim to arbitration. On refusal of person taking up an estray ts accept compensation or submit to arbitration, owner, on depositing compensation in court, may recover in replevin.

\section{APPRAISERS' FEES.}

The appraisers of estrays shall receive fifty cents each for each appraisement, but when more than one animal is taken up at any one time by one person, they shall all be appraised as one, and the appraisers shall be entivled to compensation for but one appraisement. The justice of the peace shall receive for his services the sum of one dollar and fifty cents.

\section{GELDING OF MALE BY TAKER-UP.}

If any horse or mule not gelded, two years old or upwards, shall be found running at large, it shall be lawful for any person to take up such horse or mule, and forthwith give notice to owner or keeper, if he be known to the taker-up, and if the owner or keeper do not appear wivnin three days thereafter and pay to the said takerup two dollars as compensation for his trouble, the taker-up shall proceed to advertise said horse or mule, and the same proceedings shall be had in every respect as hereinbefore provided in cases of estray horse or mules; Provided, That the taker-up may, after the expiration of twenoy days from the time of advertising, geld, or procure to be gelded, the said horse or mule, which shall be done at the risk and expense of the owner. 


\section{TAKER-UP NOT LIABLE FOR LOSS BY DEATH.}

Should any animal taken up as an estray die while in possession of the person taking it up, he shall not be liable for the loss unless its death was the result of mistreatment or willful neglect.

\section{PITFALLS AND OLD WELLS MUST BE FILLED.}

Hereafier it shall be unlawful for the owner or holder of any real estaite in the state of Nebraska to leave uncovered any well or other pitfall into which any stock may fall or receive injury, but all old wells nous in use and every other pitfall shall be filled with dirt from the bottom to the level of the surface. Provided, That if any person shall make complaint to the road overseer of the road district in which any well or pitfall upon the land of any non-resident in his district is open, its shall be the duty of such road overseer to immediately cause to be filled, or if such land is not a common, securely covered, such well or pitfall and file a bill for the same with the County Clerk which, when approved by the County Commissioners, shall be filed with the Treasurer of the County and the same is hereby made a lien upon such real estate and the County Treasurer shall collect it the same as other tax is collected upon such real estate.

\section{ROAD OVERSEER TO SEE SAME ARE FILLED}

The road overseer shall receive two (\$2.00) per day for the time actually engaged in enclosing or filling dangerous wells and pitfalls and a reasonable compensation for all material furnished. He shall file his claim with the County Clerk who shall present it to the County Board at their next meeting following. The board shall pass upon it and upon their recommend the clerk shall draw a warrant upon the County Treasurer for the amount allowed. Said warrant 0 be drawn against the general fund.

\section{NOTICE GIVEN TO OWNER.}

Twenty days notice in writing shall be given to residents. Non. residents shall be notified by publication in the legal county newspaper. The notice shall run for three consecutive weeks.

\section{PENALTY FOR VIOLATION.}

Any resident free holder leaving any well or pitfall unenclosed or unfilled into which stock may fall shall be fined in any sum noł exceeding five hundred $(\$ 500.00)$ dollars nor less than fifty dollars and liable to the owner of said stock for all damages. The same to be collected in any court of competent jurisdiction. 


\section{Diseased Stock and Quarantine Laws}

SECTION 1. LIVE STOCK SANITARY BOARD; VETERINARIAN. Appointment, interpretation. A board of five members is hereby established to be known as the Nebraska Live Stock Sanitary Board. "Wherever in the statutes of Nebraska shall occur the term "board," or any other term referring to state officials dealing with live stock diseases, the same shall be construed to mean the Nebraska Live Stock Sanitary Board, for convenience referred to herein as the Sanitary Board. The governor shall be state veterinarian, and shall appoint five members, all duly qualified electors of Nebraska, to act as a state sanitary board, one member of whom shall be engaged in the breeding of horses, one in the breeding of cattle, one in the breeding of swine, all of whom shall be actively engaged in breeding and maintainig of live stock; one member shall be a representative of the Union Sitock Yards at South Omaha, and one shall be a licensed veterinarian who is a graduate of some regularly organized school of veterinary, medicine and surgery which is recognized by the Bureau of Animal Industry and who has had at least three years of actual practice. The members first appointed, shall hold office for five, four, three, two and one years respectively said terms of office to begin within thirty days after their appointment. The successor of each shall be appointed for a term of five years. Vacancies occurring from any cause shall be filled by appointment by the governor. Provided that the member representing the Cattle Industry shall raside at the time of his appointment west of the 100th Meridian.

SEC. 2. DUTIES, POWERS. It shall be the duty of the sanitary board to protect the health of live stock in Nebraska, to determine and employ the most efficient means for the prevention and eradication of contagious and infectious disease's of live stock, to exercise by authority of the state veterinarian the power of quarantine when necessary, and to regulate the arrival into and departure from the state or any point therein of animals infected or having been exposed to infection. Provided, that this section shall not apply to live stock brought into Nebraska for immediate slaughter and therefore subject to government regulation. Whenever possible the sanitary board shall co-operate with the United States Gov? ernment in enforcing Federal regulations.

SEC. 3. OFFICES, MEETINGS, RULES, COMPENSATION OF OFFICERS. Suitable furnished offices for use of the sanitary board and its employees shall be furnished in the state capitol building. Not to exceed four regular meetings each year shall be held in said offices; special meetings shall also be held when deemed necessary. No member of the sanitary board shall receive any compensation for his services on said board other than his necessary expenses incurred in such service, saidl expenses to be paid from the state general fund. The sanitary board shall make all necessary rules to carry into effect the purposes of this act, and shall have said rules together with said act, printed in pamphlet form for free distribution. Brief press notices regarding the work of said board shall also be published from time to time. At the first meeting of the sanitary board the members thereof shall take the oath required of state officers, and shall then elect a president and secretary.

SEC. 4. EMPLOYES. The sanitary board shall recommend to the state veterinarian a candidate for the office of deputy state veterinarian, the same to be licensed veterinarian who is a graduate of some regularly organized school of veterinary, medicine and sur- 
gery which is recognized of the Bureau of Animal Industry and who has had three years actual practice, who shall receive such salary as the board deems proper, but not to exceed twenty-four hundred dollars together with the actual expenses incurred in the discharge of his duties. Before entering upon such service he shall take an oath for the faithful and efficient performance of all duties required of him by this act, and he shall give satisfactory bond to the state of Nebraska in sine sum of five thousand dollars. The state veterinarian shall appoint such other assistants as are necessary to carry out the provisions of this act. The sanitary board may recommend candidates for such appointments. If for any reason an employe fails to honorably and successfully perform the duties for which engaged said Board may recommend such employes' immediate discharge.

\section{SEC. 5. DUTIES OF DEPUTY STATE VETERINARIAN-}

The ciuties of the deputy state veterinarian shall be as follows: 1 . To secure accurate information regarding the existence of contagious, infectious and epizootic diseases of animals, and to make a scientifc study of same, together with causes, preventatives, and cures thereof. 2. To report in plain terms at the quarterly meetings of the sanitary board the results of such study, together with information regarding the detection of symptoms of disease, sanitary and other measures for preventing its spread, and the best known treatment and remedies for same, such information also to be given all other possible publicity as said Board may deem necessary. At said quarterly meetings shall also be reported full details of the work done by the state veterinarian, deputy state veterinarian and their employes during the preceding quarter. 3. To enforce all orders and rules made by the sanitary board.

SEC. 6. DUTY OF THE PUBLIC. It shall be the duty of any person who believes or suspects that any animal belonging to himself or another is affected with a contagious or infectious disease, to immediately report such belief or suspicion to the sanitary board or to some representative thereof.

SEC. 7. RIGHT OF EXAMINATION. ARRESTS. Any person owning or having charge of live stock thought to be affected with a contagious or infectious disease who refuses to allow examination of same by the state veterinarian or his authorized representative, or interferes with such examination, shall be deemed guilty of a misdemeanor, and upon conviction thereof, shall be fined not less than fifty dollars or more than two hundred dollars. In performing the above mentioned duties the state veterinarian or his representative shall have power to call for the services of any sheriff, deputy sheriff, or constable, such services to be paid for at usual rates. For the purpose of this act the state veterinarian and deputy state veterinarian and authorized assistants are hereby authorized to administer oaths and affirmations. Any officer may arrest without a warrant, take before a county magistrate and hold until a warrant can be issued, any person found violating the provisions of this act. Such officers shall immmediately notify the county attorney of such arrest, and the latter shall legally prosecute the offender, who upon conviction shall be de'emed guilty of a misdemeanor and fined not less than twenty-five dollars or more than five hundred dollars, or be imprisoned not less than thirty days or more than ninety days.

SEC. 8. EMERGENCIES. Iu case of a serious outbreak of any contagious or epizootic disease among live stock in Nebraska, the checking of which cannot be accomplished without additional funds, the sanitary board shall present such fact to the governor, who may then authorize the incurring of a deficiency to meet the emergency. 


\section{ANIMALS EXAMINED AND APPRAISED.}

Glandered horses or mules shall not be killed as such unless they have been inspected by the Deputy State Veterinarian or his assistant, and are pronounced by him diseased. Whenever any such animal becomes affected with glanders, its cash value ais the same would be were it no"s thus affected, shall be fixed within twenty-four hours before killing by appraisers chosen in the following manner: One appointed by the State Veterinaxian, one by the owner and the third by the first two. Provided, that in no case shall the appraised value of the glandered horse exceed two hundred $(\$ 200.00)$ dollars for animals so killed, not to exceed two-thirds of said amount as appraised shall be paid to the owner by the state. In no case shall any such animal be so appraised or paid for unless it be at least one year old, and have been in good faith owned and kept within the state for one year next before the killing. The award of the apparisers shall be certified by the Deputy State Veterinarian to the Auditor of the state, who shall draw a warrant upon the State Treasurer for two-thirds of the amount so appraised and certified, to be paid to the owner of the animal killed.

\section{PENALTY FOR HARBORING OR BRINGING INTO STATE.}

Any person who shall knowingly bring into the state any domestic animal which is affected with any infectious or contagious disease, or shall knowingly keep or harbor such animal except for scientific or experimental purposes shall be deemed guilty of a misdemeanor, and upon conviction shall be fined in any sum not less than One Hundred Dollars $(\$ 100.00)$, nor more than One Thousand Dollars $(\$ 1,000.00)$.

\section{PENALTY FOR ALLOWING TO RUN, OR SELLING OF DISEASED ANIMALS.}

Any person who shall have in his possession any domestic animal affected with any contagious or infectious disease, knowing such animal to be so affected, or after having received notice that such animal is affected, who shall permit such animal to run at large or who shall keep such animal where other domestic animals not affected or previously exposied to such disease may be exposed to its contagion or infection, or who shall sell, ship, drive or give away such diseased animal or animals, which have been exposed to such infection or contagion, or who shall move or drive away any domestic animal in violation of any direction, rule or order establishing and regulating quarantine shall be deemed guilty of a misdemeanor, and upon conviction thereof shall be fined in any sum not less than fifty dollars $(\$ 50.00)$ nor more than two hundred dollars $(\$ 200.00)$ for each of such diseased or exposed animals which he shall permit to run at large, or keep or drive, trade or give away in violation of the provisions of this act. Provided, That any owner of domestic animals which have been affected with or exposed to any contagious or infectious disease, may dispose of the same after having obtained from the State Veterinarian a bill of health for such animal.

\section{PENALTY FOR USING OR ALLOWING GLANDERED HORSES TO RUN.}

It shall not be lawful for any person to use, let, sell, or permit to run at large any horse, mule, or ass diseased with glanders. Any person violating the provisions of this section shall pay a fine of not less than five or more than fifty dollars, and shall be liable for all damages. 


\section{ATTENTION! STOCKMEN AND FARMERS One Giant Pipe Pusher Free in Each County for Advertising Purposes}

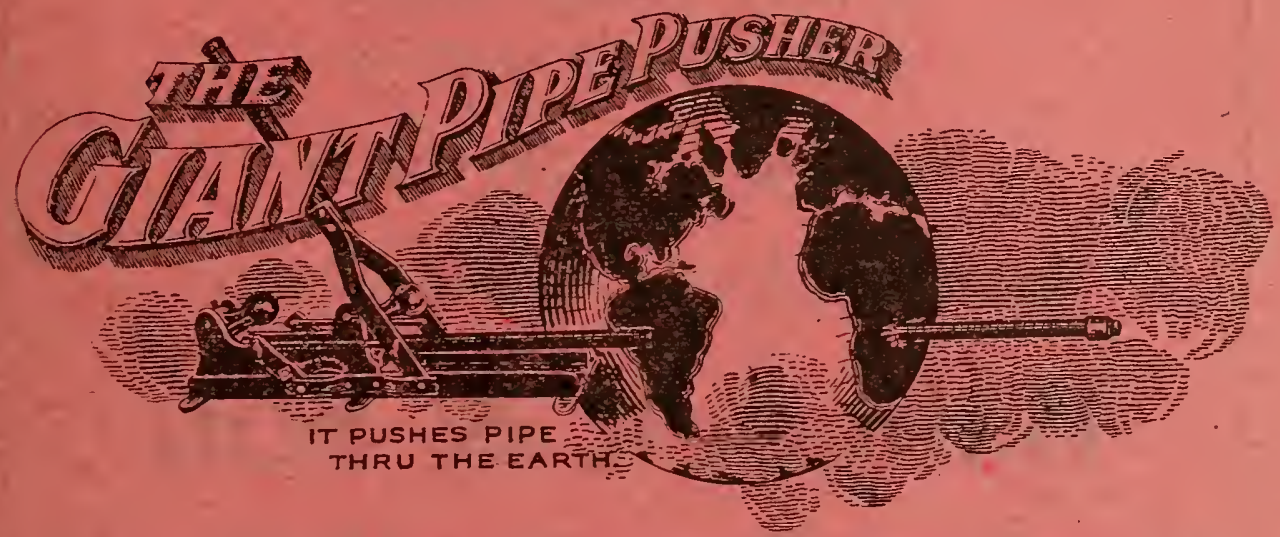

One pusher does the work of ten men. Saves fine lawns and draws trade. Offers enormous profits to young men in pushing pipe for stockmen and farmers.

Invariably when we sell a Giant Pipe Pusher other orders follow in rapid succession. Fo this reasen the cheapest and most effective way to advertise is to ship one Giant Pipe Pusher free of charge into each county. We mean it. Write for particulars.

\section{GIANT MANUFACTURIYG CO., Council Bluffs, Iowa}

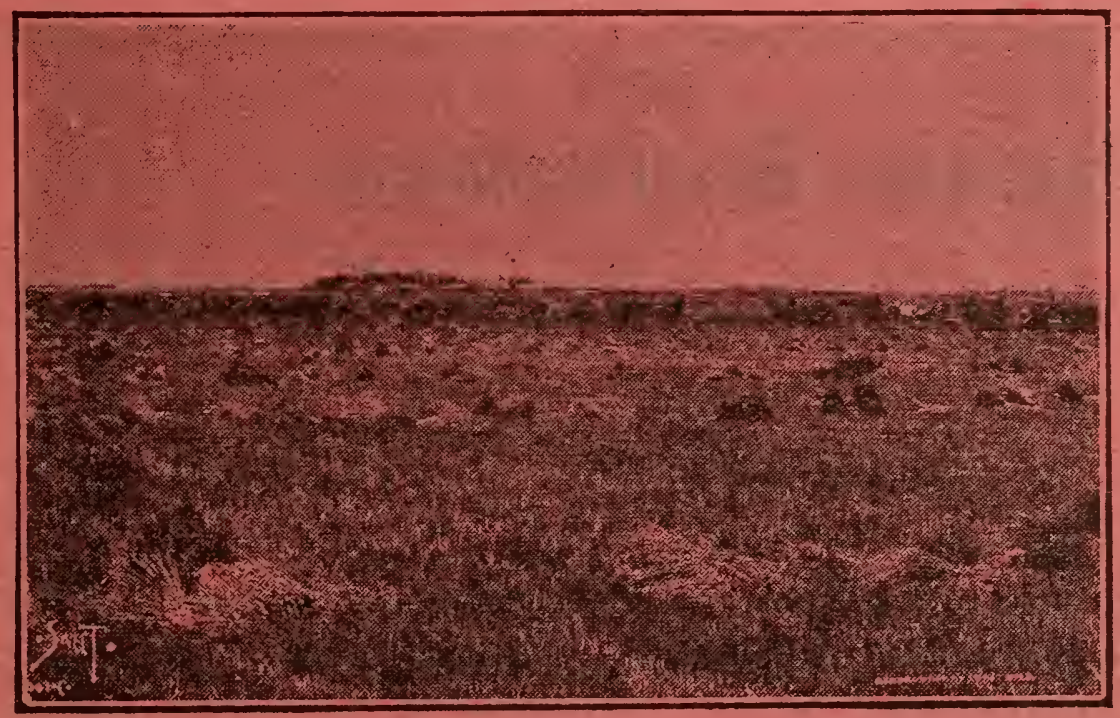

A Harvest Scene in Clay County of the Red River Valley.

Did it ever occur to you that Mincesota is the greatest all-around crop producing state in the Union, and no other state can match her in stock and dairying, and that you can buy improved and unimproved land in. Clay County, and counties adjoining it at from $\$ 35.00$ to $\$ 75.00$ per acre, on easy terms, low rate of interest and perfect title? In a short time these prices will have doubled. We have never had a crop failure. Our people do not sell out to move away from the state. They sell because they are well enough situated financially to retire. If you ever hope to own a home, now is the time to start. We conduct cxcursions on first and third Tuesdays of every month out of all points of Nebraska, Iowa, Illinois and Wisconsin. Come to our Immigration offlce, 612 Bee Bldg., Omaha, Neb., and we will assist you to procure low rates to Hawley. Clay County, Minnesota, where is located our

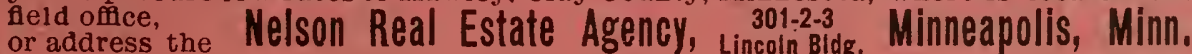




\section{Our Motto: \\ Every Man's Stuff Sold on it's merits \\ We have no favorites \\ Consign Your Shipments to \\ Babcock \& Son \\ Live Stock Commission Merchants}

E. B. BABCOCK, S. E. BABCOCK, Cattle Salesmen

W. H. TIMMEL, Hog Salesman

Reference: Live Stock National Bank.

Room 217 Exchange Bldg., Sioux City, Iowa

\section{Pleasures Gastronomical-.-}

\section{Prices Economical}

\section{At the BELMONT RESTAURANT}

The epicure who comes here remembers the occasion with fond recollections. Quick Service Food that tickles your palate and an attractive scale of prices is a combination that always fascinates our dinners. The pure food law and restaurant inspection are a superfluous issue in our establishment. One meal will be enough to convince you, that you have found the best place in town to eat.

$$
\text { C. N. BALL, Prop. }
$$




\section{RECOVERY OF FINES AND FORFEITURES.}

All fines and forfeitures incurred under the provisions of this act shall be recovered by action before any justice of the peace, and all such fines shall be paid into the school fund, in and for the county having jurisdiction of the case.

\section{DEFENDANT MAY BE COMMITTED BY JUSTICE UNTIL PAYMENT HAD.}

In all cases of conviction under the prvoisions of this act, the justice shall enter judgment for the fine and cosis against the defendant, and may commit him unvil the judgment is satisfied, or issue execution on the judgment for the use of the common schools of the county.

PENALTY FOR BRINGING DISEASED ANIMALS INTO STATE.

I3 shall not be lawful for the owner of any domestic animal or animals or any person having them in charge, knowingly to import or drive into this state any animal or animals having any contagious or infectious disease; and any person so offending shall be deemed guilty of a misdemeanor, and shall be punished by fine in any sum not less than $\$ 1$ or more than $\$ 100$, and be imprisoned in the county jail not more than three months, or both, in the discretion of the court.

\section{PENALTY FOR ALLOWING DISEASED ANIMALS TO RUN.}

Any person being the owner of any domestic animal or animals, or having the same in charge who shall turn out, or suffer any such domestic animal or animals having any contagious or infecious disease, knowing the same to be so diseased, to run at large upon the unenclosed land, common, or highway or shall let the same approach within twenty rods of any highway, or shall sell or dispose of any domestic animal or animals, knowing the same to be so diseased, without fully disclosing the fact to the purchaser shall be deemed guilty of a misdemeanor, and shall be punished by a fine in any sum not exceeding five hunared dollars, and imprisoned in whe county jail not less than six months.

\section{ACT CUMULATIVE AND DOES NOT PREVENT DAMAGE SUIT.}

Nothing in this act shall be so construed as to prevent the recovery of damages in a civil action against any person or persons who shall sell, trade, or import, or drive into whis state such diseased animal or animals, or who shall allow such domestic animal or animals to run at large, or to approach nearer than twenty rods of any highway.

\section{VIOLATER OF ACT ALSO LIABLE IN DAMAGE.}

Any person violating any of the provisions of this act in addition to the penalities herein provided, shall be liable for all damages that may accrue to the party damaged by reason of said diseased animal or animals imparting disease.

\section{OWNER MUST BURN DISEASED STOCK.}

The owner of any swine which die from disease or sickness shall have the carcass of the same completely burned on the premises where the animal died within forty-eight hours after death. Any person violating this Section shall be guilty of a misdemeanor and upon conviction thereof be fined in any sum not to exceed ten $(\$ 10.00)$ dollars.

\section{ROAD OVERSEER SEE THAT ACT IS ENFORCED.}

It is hereby made the duty of the road overseer in each road district to enforce the provisions of this Acs by filing complaint against the person so offending with the nearest justice of the peace 
or with the county judge upon knowledge of any violation of this Act. Road overseers shall be allowed for the actual and necessary time required for vine enforcement of this Act the same pay as when engaged in their other duties. A failure or neglect to file such complaint within three days after notice or knowledge of the same shall disqualify the person so failing or neglecting from holding any county, township or precinct office in said county for the period of two years from such failure or neglect. Proof of such failure or neglect may be made on complaint of any citizen before the county judge of the county wherein the failure or neglect is alleged to have occurred.

\section{HAULING OFF ON HIGHWAY PROHIBITED.}

If any person shall remove, or convey along any public highway, road, alley or stree the carcass of any swine that has died from sickness or disease, shall be guilty of a misdemeanor and upon conviction thereof shall be fined not less than Twenty-five $(\$ 25.00)$ dollars, or more than One Hundred $(\$ 100.00)$ dollars, or be imprisoned in the county jail not exceeding three months.

\section{MANUFACTURERS FORBIDDEN TO USE.}

If any person or company engaged in the business of manufacturing soap, or rendering lard or oil, shall receive, or have in their possession whe carcass of any swine which has died from sickness or disease shall be guilty of a misdemeanor and upon conviction shall be fined not less than Twenty-five $(\$ 25.00)$ dollars, or more than Three Hundred. $(\$ 300.00)$ dollars or be confined in the county jail not to exceed three months.

\section{SHEEP INSPECTOR-APPOINTED BY COUNTY BOARD.}

Whenever, in any county in this state, a majorioly of the sheep owners therein shall petition the board of county commissioners of their county, for the appointment of a sheep inspector, recommended by a majority of petitioners in such counisy it shall be the duty of the said board of county commissioners to appoint some suitable, competent person sheep inspector in and for said county.

\section{WHO ELIGIBLE-BOND AN OATH OF.}

Such person shall be a resident of the county for which he shall be appointed. He shall, before entering upon the duvies of his office, take the oath prescribed for other county officers, in chapter ten, compiled Statutes of the State of Nebraska (9400), and shall give a bond in the sum of one thousand dollars payable to the county in which he shall be appointed, with two sureties to be approved by the county clerk of such county, which bond shall be filed and recorded in the office of such clerk.

\section{TERM OF OFFICE.}

Every inspector shall hold his office for two years from the date of his appointment, and until his successor is duly appointed and qualified.

\section{VACANCY FILLED BY COUNTY BOARD.}

The board of county commissioners of each county where the office of sheep inspector exists, shall by appointment fill all vacancies occurring in said office, or about to occur by reason of the expiration of the term of any incumbent; Provided, That if a majoriuy of the sheep owners of any such county shall petition the board of county commissioners thereof to abolish said office such board may in its discretion abolish the same, to take effect upon the expiravion of the term of the then incumbent. 


\section{POWERS AND DUTIES WITH INFECTED FLOCKS.}

Every sheep inspector upon inspecting any flock of sheep and finding the same or any part thereof infected with what is commonly called the "scab" or any ouher contagious disease, shall, in the manner hereinafter prescribed, have the power to define, limit and restrict the range and feeding grounds of such sheep for such time and in such manner as to him may seem necessary to protect all neighboring flocks from becoming likewise infected, and notify the owners or agent of the diseased flock; then he shall, within ten days from the day of inspection, commence the curing of same, and it shall be the duty of the inspector to inspect said flock every twenty days until the flock is found cured, for which he shall receive the same compensation as provided in secion 12 (3210) and all persons who may be selected arbitrators under this act shall, in conjunction with such inspector, have like power.

\section{INSPECTION RECORD KEPT BY.}

Every inspecior shall keep a book, to be known as "Inspection Record," in which he shall enter and record all his official acts and proceedings. Such record shall particularly show the name of the owner of every flock of sheep inspected, when the same was inspected, the result of such inspection, and all orders and directions made in relation thereto.

\section{WHEN· MAKE ANNUAL INSPECTION.}

It shall be the duty of every sheep inspector, between the 15 th day of May and the 15: day of August in each year, to make a careful inspection, to be known as the annual inspection, of every flock of sheep kept in his county, and determine whether or not such sheep are free from scab and other contagicus disease.

\section{INSPECT FLOCK ON COMPLAINT.}

It shall further be the duty of every inspector, upon information and complaint made in writing before any justice of the peace and filed with the inspector, setting forth that any flock of sheep, describing io within the jurisdiction of such inspector, has the scab or any contagious disease, to forthwith inspect such flock as to the truth of such complaint; and if upon inspection it shall be found such flock is inflicted with a contagious disease, the owner shall pay "she expense of such inspection, otherwise the person lodging the complaint shall pay such costs, and shall be liable in a civil action therefor.

\section{INSPECT FLOCK SHIPPED IN FROM OTHER STATE.}

Upon the arrival of any flock of sheep in any county in this staive in which there is a sheep inspector, it shall be the duty of the inspector in such county, having knowledge of such arrival to forthwith inspect such flock as to whether or not it is free from scab, or other contagious disease; Provided, If the owner of such flock or his agent shall, immediately upon such arrival, repor's the same to the sheep inspector, and at the same time exhibit to such inspector the certificate of any duly appointed and qualified sheep inspector in whe state that such flock has been by him duly inspected within one month of such arrival and found free from every contagious disease, then such inspection shall not be necessary.

\section{QUESTIONS ASKED BY INSPECTOR.}

Upon inspecting any flock of sheep it shall be the duty of the inspector to require the owner of such flock or in his (the) absence of his agent, true answers to the following questions: First. The name of the owner of such flock, his earmark and brand. Second. The increase of such flock by purchase or trade since the last inspection. 
Third. From whom such increase has been received. Fourth. From what county and state such increase came. Fifth. Whether or not any part of them was, at the time inspected (infected) with the scab or any contagious disease, and, if so, what disease. Such owner or agent, as the case may be, shall make true answers to all such questions, and subscribe the same and make oath thereto, all of which shall be entered in the inspector's record. The inspector shall have power and is hereby authorised to administer an oath.

\section{POWIERS AND DUTIES ON INSPECTION OF INFECTED FLOCKS.}

If upon the inspection of any flock of sheep the inspector shall find the same or any part thereof infected with the scab or any contagious disease, it shall be his duty at once to define, limit, and restrict the range and feeding grounds of such flock, as authorised in section 5. (3203) of this act. The inspector shall, at the time of making any order or direction authorized by this act, enter the same, in full in his inspection record, and shall at once make out in writing a true copy thereof, and deliver the same to the owner interested, or in his absence to his agent in charge of such flock of sheep, and the owner of said sheep and all persons under him shall fully comply with the terms of the copy so served; Provided, If the owner of such sheep, or the person so served with such copy, shall consider the terms thereof unreasonable, he may, within twenty-four hours after receiving the same, so notify the inspector in writing, naming therein some disinterested person being the owner of one hundred sheep or more, arbitrator, to act in review on all matters contained in such order and copy, which person, with the inspector, shall without delay select some other like person, and the two thus chosen with the inspector shall forthwith make such orders and directions authorized in section five (3203) of this act, as to them may seem reasonable and just, and their action in the premises shall be final. Every order and direction shall be entered in full on the inspector's record, and be signed by the arbitrators and inspector making the same, and a true copy thereof served without delay on the owner interested or his agent in charge.

\section{FEES OF INSPECTOR AND ARBITRATORS-HOW PAID.}

The inspector and arbiurators shall receive for their services the following fees and no more, which shall be paid by the owner of the flock inspected, except as otherwise provided in this act: The inspector shall receive for each flock inspected at each annual inspection the sum of one dollar, and in addition thereto the sum of ten cents for every hundred sheep inspected, or fractional part thereof, to be paid by the owner of the flock inspected. For every other inspection the sum of three dollars per day for each day necessarily employed in such duty. Each arbitrator shall receive three dollars per day for each day necessarily employed in their duties.

\section{PENALTY FOR FAILURE TO COMPLY WITH INSPECTOR'S DIRECTIONS.}

Any person who shall fail to comply with or disregard any order or directions made by the inspector and arbitrators, under the provisions of this act, shall upon conviction be fined in any sum not less than one hundred dollars.

\section{OWNER LIABLE FOR DAMAGES TO OTHER FLOCKS AND HERDS.}

Any person or persons owning or keeping any flock or herd of sheep, any portion of which flock or herd is diseased with the scab or other contagious disease, shall be liable to any person damaged thereby in double the amount of damage such person may sustain by 
reason of such flock or herd or any part thereof being moved or allowed to stray from the premises of the owner of such flock.

\section{CARE OF DISEASED SHEEP-FINE.}

It shall be unlawful for any person or persons having a flock or herd of sheep, any portion of which is infected wilh the scab or any infectious or contagious disease, to allow such flock or herd or any part thereof to stray or be driven upon the grounds of another without the consent of the occupant ihereof in writing, or to allow any such flock or any part thereof to come in contact, off his premises, with the sheep of any other person. Every person so offending shall be fined in any sum not less than five dollars nor more than one hundred dollars.

\section{BRINGING INTO STATE OF DISEASED SHEEP.}

It shall be unlawful for any person or persons to bring into this state from without the state any sheep infected with the scab or any contagious disease. Every person so offending shall upon conviction thereof be fined in any sum not less than fif'sy dollars nor more than one hundred dollars, or imprisoned in the county jail not less than one month or more than three months, or both at the discretion of the court.

\section{BRANDS AND EAR-MARKS RECORDED IN OFFICE OF COUNTY CLERK.}

Every person or persons being the owner of any sheep shall cause such sheep, and all of them six months old and upwards, to be suitably branded and ear-marked. which brand and ear-mark shall be made of record in the office of the ocunty clerk of the county in which such sheep are kept. Every person failing to comply with the provisions of this section shall, upon convic'sion thereof, be fined in any sum not less than five nor more than fifty dollars.

\section{NO PROPERTY EXEMPT FROM SALE.}

No property shall be exempt from sale under execution issued upon any judgment obtained under any of the provisions of this act. OWNERS OF DOGS LIABLE FOR DAMAGES DONE.

Tha's dogs are hereby declared to be personal property for all intents and purposes and the owner or owners of any dog or dogs shall be liable for any and all damages that may accrue to any person, firm, or corporation by reason of such dog or dogs killing, wounding, worrying or chasing any sheep or other domestic animals belonging' to such person, firm or corporation and such damage be recovered from any court having jurisdiction of the amount claimed.

\section{PERSONS JOINTLY AND SEVERALLY LIABLE-WHEN}

If two or more dogs owned by different persons shall kill, wound, chase or worry any sheep or ousher domestic animal, such persons shall be jointly and severally liable for all damages done by such dogs.

\section{RIGHT TO KILL DOGS-WHEN.}

Any person shall have the right to kill any dog found doing any damage aforesaid to any sheep or domestic animal, or shall have just and reasonable ground to believe that such dog has been killing, wounding, chasing or worrying such sheep or animal, and no action shall be maintained for such killing.

TO PREVENT THE SPREAD OF DISEASE AMONG SHEEP.

Any person being the owner of sheep or having the same in charge, who shall turn out, or suffer any sheep having any contagious disease, knowing the same to be so diseased, to run at large upon any common highway, or enclosed ground, or who shall sell any such. 
sheep, knowing the same to be diseased, without fully disclosing the fact to the purchaser, shall be punished by a fine of not less than twenty dollars and not more than one hundred dollars, and be imprisoned in the jail of the county not exceeding three months, in the discretion of the court; provided however, this section shall not be so costrued as to prevent any person from owning such diseased from driving them along any public highway.

\section{SELLING OR ALLOWING DISEASED ANIMALS TO RUN AT LARGE.}

It shall be unlawful for any person to sell, barter or dispose of, or permit to run at large, any horses, cattle, sheep, or domestic animal, knowing that such horse, cattle, sheep, or domestic animals are infected with contagious or infectious disease, or have been recently exposed thereto, unless he shall first duly inform person to whom he may sell, barter or dispose of such horse, cattle, sheep or other domestic animal, of the same; and any person so offending shall be fined in any sum not less than twenty dollars nor more than one hudred dollars, or be confined in the jail of the county not exceeding three months.

\section{ALLOWING DISEASED ANIMALS TO COME IN CONTACT} WITH OTHERS.

If any person, being the owner or having charge of any horse, cattle, sheep, or any kind of stock knowing the same to be infected with contagious or infectious disease, shall knowingly permit it to come in contact with any other person's horses or stock, without such person's knowledge or permission, such person shall be fined in any sum not less than fifty nor more than five hundred dollars, or be confined in the jail of the county not less than ten nor more than fifty days.

\section{HOG CHOLERA-CARCASSES NOT SOLD.}

If any person owning, or assuming to own or control swine, any of which have died from disease or sickness or shall dispose of the carcasses of said animals for any purpose whatever; or shall render into lard or oil, the said carcasses; or if any person who shall buy or receive the carcasses of said dead animals, shall be guilty of a misdemeanor, and upon conviction thereof shall be fined in any sum not less than Twenty-five $(\$ 25.00)$ Dollars or more than One Hundred $(\$ 100.00)$ dollars, or be imprisoned in the county jail not to exceed three months.

\section{DISEASED CATTLE NOT TO RUN AT LARGE-PENALTY.}

That every person shall so restrain his diseased or distempered cattle, or such as are under his care, that they may not go as large; and no person or persons shall drive any diseased or distempered cattle, affected with any contagious or infectious disease, into or through this state or from one point thereof to another. Any person or persons offending against this section shall, on conviction thereof before any justice of the peace, forfeit not less than five nor more than twenty-five dollars for every head of such cat'sle, and be liable for all costs and damages.

\section{JUSTICE OF THE PEACE IMPOUND DISEASED CATTLE.}

Any justice of the peace, upon proof before him that any cattle are going at large or are driven in or through his county, in vioation of the proceding section, shall order a constable or sheriff to impound them, and the owner thereof shall be held liable for all costs and damages. 

FEE-PENALTY.

The sheriff or constable who may execute the order of any justice of the peace as aforesaid, to impound any such cattle, shall have twenty-five cents per head for the first fifty and five cents for each additional head to be paid by the defendant upon conviction thereof, but in case the defendant be discharged, then said costs to be paid by the complainany; and if any officer to whom any order under this law is directed shall fail to execute, he shall forfeit in case of a failure a sum not less than one hundred dollars.

\section{HOG CHOLERA SERUM PLANT.}

There shall be established by the board of regents of the State University a plant for the production and preparation of the hog cholera serum discovered by the Biochemic Division of the Bureau of Animal Industry, Washington, D. C. Said plant shall be under the regulation and control of the board of regents of the Nebraska State Universitsy.

\section{DEPARTMENT OF ANIMAL PATHOLOGY-CONDUCT.}

The Department of Animal Pathology of the State University shall carry on the production and preparation of said serum under the provisions of this act and shall deliver to the Nebraska State Veterinarian, or his authorized deputies, said serum at the actual cost of production for so much as said serum shall be used and applied under the direct supervision of the State Veterinarian or his Deputies. Said Department shall also distribute said serum to farmers and swine growers, residents of Nebraska, at the actual cost of its production.

\section{APPROPRIATION FOR.}

There is hereby appropriated out of any money in the general fund not otherwise appropriated, the following sum for the purpose of carrying out this act: For buildings, plant and equipment, expenses of operating and maintenance, and all o sher expenses incurred in the necessary scientific distribution and application of serum by this Department of the State Veterinarian or his deputies $\$ 15,000.00$.

\section{RECEIPTS FROM SALE OF SERUM.}

All moneys collected from the sale of said serums as provided for in Section 2 of this Act, shall be paid into the operation and maintenance fund, and the same is hereby appropriated for the continuing operation of the plant.

\section{MANUFACTURE OF SERUM AFTER MONEY EXHAUSTED.}

Production and preparation of said Hog-cholera serum may be carried on after the exhaustion of the appropriation made herein, to meet any furthed demands, provided said serum is then sold at the full cost of its production. 


\section{Brands}

\section{BRANDING STOCK.}

Any person or persons having cattle, hogs, sheep, horses mules or asses, shall have the right to adopt a brand or mark, for the use of which he shall have the exclusive right in this state, after recording such brand or mark as hereinafter provided.

\section{RECORDING-FEES.}

The Secretary of State shall, as soon as practicable after the passage of this act, procure a suitable book, or books, in which all brands and marks shall be recorded. Each person desiring a brand, or mark, r'ecorded as hereinafter provided, shall pay in'so the office of Secretary of State, a fee of $\$ 1.50$, for recording such brand or mark. And every five years thereafter, the owner of any recorded brand, or mark, shall pay to the Secretary of State the sum of 50 cents, for the re-recording of such brand or mark: Provided, that all brands and marks prior Jo July 1, 1906, must be re-recorded before January 1, 1908.

\section{BRANDS RE-RECORDED EVERY FIVE YEARS.}

The Secretary of State shall notify the owner of any recorded brand by letter on or before September 1, 1907, and on or before September 1, every nive years thereafter of the time for recording his brand and any brand, or mark, the owner of which who fails to have same re-recorded as above provided becomes cancelled and may be used by another. Such fees shall, by said Secretary of State, be turned over to the State Treasurer for use in the general fund, and by said treasurer be receipted for.

\section{BRANDS MUST NOT BE DUPLICATED.}

No person shall have or adopt a brand or mark previously recorded under this act to any other person if used on the same side; neither shall the secretary of state record the same brand or mark to more than one person, unless for opposite side.

\section{BRANDS IN ACTUAL USE FILED WITH SECRETARY OF STATE.}

Any person desiring to use any brand or mark shall make and sign a certificate setting forth a facsimile and description of the brand and mark which he desires to use or to which shall be attached a certified copy of the jecord of such brand and mark from any county in which the same shall have been recorded, if so recorded, and showing the date of such record, and shall file the same for record in the office of the Secretary of State; Provided, That no brand shall be filed or registered unless the same is in actual use.

\section{DECIDE ON BRANDS OFFERED FOR RECORD.}

The authority of deciding whether a brand or mark offered for record does or does not conflict with any previously recorded brand or mark shall be vested in the secretary of state. All brands offered for record shall be submitted before acceptance to said secretary of state; Provided, That no brand described as being on either side of the animal shall be accepted or recorded; Provided, further, That a brand described as being on both sides may be accepted. It shall be the duty of the secretary of state to file all brands offered for record pending the examination, which he shall cause to be made as promptly as possible; and if the brand is accepted the ownership shall date from the date of filing. 


\section{IF TWO BRANDS ARE SIMILAR, LAST ONE RECORDED ILLEGAL.}

The secretary of state shall examine any evidence of brands or marks, or records thereof, which may heretofore have been made in the office of any register of deeds of this state, and any other evidence of such marks or brands which mav be presented by the owner, and in any case, where a brand or mark is found which conflicts with one previously recorded, or which might in its use endanger the property of the party owning the brand or mark earliest of record, it shall be the duty of the secretary of sitate to notify the party owning said brand last of record that the further use of same shall be illegal to the same extent as though it had never been recorded, unless previously agreed upon by owner of such brands or marks and a joint statement be presented to the secretary of state by such brand owners. This said notice shall be given by letter. It is expressly provided that this enactment shall not in any way affect or invalidate the ownership of animals which were branded with said brand then registered previous to such examination and rejection, the object of wis act being to make illegal and enjoin from the further use of said brand.

\section{BROUGHT IN FOR GRAZING, BEAR DISTINGUISHING BRAND}

It shall be the duty of any person who, after the passage of this act, brings into any county of this state and turns loose for grazing purposes any herd brand or individual animals already branded, to lay before the secrevary of the state a statement of the brands of said animals, and if said brands conflict with any previously recorded it shall be the duty of this owner or manager of said animals to brand them with a brand that the secretary of state shall consider a full and disinguished mark from all brands there recorded, but the owner shall be enjoined from further use of the conflicting brand. A failure to comply with the provisions of this section shall render the party so failing liable for all damages resulting from such failure, which damages may be recovered in a civil suit. It is further provided what this section shall apply to all animals now in any county in this state whose brands are considered by said secretary of state to infringe on previously recorded ones.

\section{BRANDS TO BE REJECTED.}

In deciding as to the conflict of brands, the Secretary of State shall reject any that, being the same as one previously recorded, has in addition, any of the following, whether placed across, above, below at either side, or encircling the main brand, viz: A straight bar, a quarter, half or entire circle, a quarter, half or entire diamond, either upright or inverted, the same not constituting a true brand and rendering the owner of the same brand liable to damages by its use, saving only when one or more of these shall be filed by the owner of the first record of the main brand in which case it may be accepted The secretary of state shall reject any brand formed by repetition of any letter, number or figure which shall have been previously recorde 3 , if on the same side of the animals, the exclusive right of the first record to the letter, number or figure, and to repetition of it, being re-affirmed. $\mathrm{He}$ shall also reject all brands, known as solid brands. and all ear marks which shall remove to exceed one-half of the ear. A variation in the size of a letter, number, or figure shall not constitute a new brand and shall ke rejected. A combination of letters, numbers, or figures may be permitted though the same letters, numbers or figures may have been recorded, single or together, if in the judgment of the secretary of state said combination is so different from any previous record as to constitute a new brand with no danger of infringement. 


\section{BRAND PRIMA FACIE EVIDENCE OF OWNERSHIP.}

In all suits at law or in equity, or in any criminal proceedings, where the ownership of any. cattle, horses, mules or swine is involved the brand upon any animal, above named, shall be prima facie evidence of ownership of the person whose brand its may be; Provided, That such brand has been duly recorded as provided by law. Proof of the right of any person to use such brand shall be made by a copy of the record of the same, certified, in case of the registry of such mark or brand under the law in force prior to March 29th, 1901, by the register of deeds of the county in which said mark or brand has been recorded under the handi and seal of the office of the said register, and in case of the registry of such mark or brand under the act of March 29th, 1901, by the register of deeds of the county in which said mark or brand has been recorded under the hand and seal of the office of the said register, and in case of the registry of such mark or brand under the act of March 29th, 1901, by the Secretary of State under the hand and seal of his office; Provided, further, That any owner or owners of any brand or brands, mark or marks may sell and transfer the same by an instrument in writing which sale and transfer shall not become effective until said instrument shall be recorded in the manner required by law for the recording of marks and brands and for which recording a like fee shall be charged which fee shall be disposed of and accounted for in the same manner as fees for recording marks and brands.

\section{PENALTY FOR VIOLATION.}

Any person or persons who shall violate or fail to obey the provisions of this act, or shall continue the use of a brand or mark after the same has been rejected by said Secretary of Stave' or shall continue to use any brand or mark after the said Secretary of State shall have decided that the same conflicts with a previously recorded brand or mark, shall be deemed guilty of a misdemeanor, and upon conviction thereof in any court of competent jurisdiction shall be punished by a fine of not exceeding one thousand $(\$ 1,000.00)$ dollars or by imprisonment in the county jail for a term not exceeding one year, or by both such fine and imprisonment, in the discretion of the court.

\section{DOES NOT IMPAIR RIGHTS OF OWNERS.}

Nothing in this act contained shall be construed to in any manner impair the property rights of owners of live stock in the state under the laws heretofore in force.

\section{BUTCHER TO RECORD MARKS AND BRANDS.}

Any person now engaged or who may hereafter engage in the business of a butcher in the stade of Nebraska shall keep a record of all branded beef animals he may slaughter, give age, sex, marks, and brands, of whom purchased and date of said purchase, which record shall at all times be open for public inspection alt his place of business.

\section{EXHIBIT HIDES.}

It shall be unlawful for any person or persons who occasionally slaughter cattle or beef to offer forsale said beef without exhibiting the hide or hides of such beef at the time and place said beef is offered for sale. And it is provided, further, that the brands on the hide so exhibited must not be changed, mutilated or destroyed.

\section{KEEP HIDES FOR AT LEAST THREE DAYS.}

All persons other than butchers, who occasionally slaughter cattle or beef, for home consumption, shall keep the hide or hides of such animals so slaughtered for a period of not less than three days, subject to inspection by any person or persons. 


\section{KEEP RECORD OF BRANDED HIDES BOUGHT.}

All purchasers of hides shall keep a record of all hides of neat cattle purchased by them, which record shall state the name or names of the person or persons from whom purchased, their place of residence, the date of purchase and all marks and brands on said hides, which shall at all times be open for the inspection of stock growers, their agents, and employes. Provided, that the provision of this section shall only apply to branded hides.

\section{PENALTY.}

Any person who shall wilfully violate the provisions of this act or wilfully neglect or refuse to do any act herein required shall be guilty of a misdemeanor and on conviction shall be punished by imprisonmeni in the county jail for a period not exceeding three months or pay a fine not exceeding one hundred dollars.

\section{ALTERING EAR MARK, OR BRAND.}

If any person shall wilfully and maliciously alter or deface any artificial ear mark or brand, upon any horse, mare, foal, filly, mule or ass, sheep, goat, or swine, cow, ox, steer, bull, or heifer the property of another, every person so offending shall be fined in any sum not exceeding fifty dollar's, and be liable in treble damages to the party injured.

\section{Stallion Laws}

SECTION 1: STALLIONS, JACKS, BULLS, LIEN FOR SERVICE. Every owner, lessee, agent or manager of any stallion, jack or bull shall be envitled to and have a lien upon any mare and her colt or upon any cow and her calf served by any such stallion, jack or bull for the full amount of the reasonable or agreed value or price of such service. Every such owner, lessee, agent or manager of such stallion, jack or bull desiring to perfect a lien upon any mare and her colt or upon any cow and her calf shall at any time after breeding any such animal to any such male file with the County Clerk of the county a verified notice of lien describing such animal with reasonable certainisy, giving the name of the owner and his place of residence if known, and the name and residence of the person having the possession of such animal, the location of such animal, the terms of payment for such service, the amount thereof, the name of the male, the date of the service, and the time or event when the same shall become due and payable, and such other matters as to make the same more certain. Thereafter such lienor shall have a first lien upon such animal or animals described therein, and their offspring as soon as the same may be born, subject, however, to the lien of record of any prior mortgage in good faitin.

SEC. 2. LIST OF ANIMALS SERVED. Any owner of any stallion, jack or bull within the state may file with the County Clerk of any county therein on or before the first day of October of each year, a full and complete list of the mares or cows served by such male within such county during that year. Such list shall contain the name of and a brief description of all animals so served. the owners thereof, the terms on which each was bred, the amount of money due or to become due upon each, and the time when payment thereof becomes due, and it shall be verified by the owner of such stallion, jack or bull or his lawfully authorized agent.

SEC. 3. LIENS, DURATION. From the time of filing such lien upon any such mare or cow the lienor shall have the right to hold the same on such mare or cow and their or its offspring for a 
period of six months from and after the birith of such offspring, but if such lien shall not be foreclosed within that time the same shall expire, and be of no force or effect.

SEC. 4. FORECLOSURE. Every such lienor may foreclose such lien by delivering to any sheriff or constable a true copy of such lien certified by the Clerk of the County, iogether with an affidavit of the lienor or any agent or attorney having knowledge of the facts, stating the amount due and unpaid on such lien with direction to such officer to foreclose such lien. Thereupon such officer shall seize such mare or cow and their or its offspring and sell the same in the manner provided by law for the sale of personal property on execution, and retain the principal and interest and expenses of such seizure and sale, and the overplus, if any, pay over to the owner of such mare or deposit the same for him with the County Clerk and make and file due return thereof with the County Clerk.

SEC. 5. ANIMALS--REMOVAL. It shall be unlawful for any owner of any mare or cow or their or its offspring, or any persons having the possession of such mare or cow or their or its offspring upon which there is a lien of record in the county so sell or permanently remove the same from the county or state before said lien is paid; provided, such owner may remove the same to an adjoining county by first filing in such adjoining county a certified copy of such lien and notifying such lienor in writing of the exact location of such mare or cow and their or its offspring in such adjoining county.

SEC. 5. VIOLATION OF ACT. Any person or persons knowingly or willfully violating any of the provisions of this act, shall be punished by a fine of not less than Twenty-five Dollars $(\$ 25.00)$ nor more than Fifty Dollars $(\$ 50.00)$.

\section{REGISTRATION OF STALLIONS AND JACKS.}

SECTION 1. STALLIONS, etc. CERTIFICATES-REGISTRATION BOARD. Every owner or keeper of any stallion or jack kept for sale', transfer, exchange or public service, who represends such stallion or jack to be fit for service, shall procure a certificate and keep the same, or an exact copy thereof, posted in a conspicuous place within every barn, shed or building in which such stallion or jack is kept for service and shall mention the same in all advertisements, as herein provided. Such cervificate shall be procured from the Stallion Registration Board, which shall be composed of the following named officers: The Governor, the State' Treasurer, the Commissioner of Public Lands and Buildings. The Board shall have power to appoint a secretary who shall be the Deputy State Veterinarian, and io employ all necessary help and maintain an office in the State Capitol.

SEC. 2. CERTIFICATES-HOW OBTAINED. In order to obtain such certificate, there shall be presented to said Stallion Registration Board an affidavit, signed by a qualified veterinarian who is not interested in the buying and selling of horses who has been appointed by said board, (said Veterinary Surgeon may be disqualified for cause), to the effect that he has personally examined such stallion or jack and that to the best of his knowledge and belief such stallion or jack is free from such hereditary, infec'vious, contagious or transmissable diseases as: urethal gleet, melanosis, periodic opthalmia (moon blindness), laryngeal hemiplegia, roaring, dourine, glanders, farcy, or serious defects in general conformation, and, if the stallion or jack is pure bred, there shall be presented to the inspector for his examination and comparison also a certificate of registration of such stallion issued by one of the following foreign stud books, and associations recognized by the Department of Agriculture 
in the Bureau of Animal Husbandry Order No. 175, November 25 1910, and amendment number one (1) thereto, December 30, 1910。 pany.

Name of breed, book of record and association, society or coma.

Belgian Draft. Stud Book des Chevaux de Trait Bleges. Societele Cheval de Trait Belge Chevalier, G. Hynderick, sec'y, Brussels, Belgium.

Clydesdale. Clydesdale Stud Book. Clydesdale Horse Soc'y of the United Kingdom of Great Britain and Ireland, Archibald IVacNeigage, Sec'y, 93 Hop St., Glasgow, Scotland.

French Draft. Studbook des Chevaux de Trait, Francais. Soeiete des Agricultures de France, Henri Johanet, Sec'y, 8 Rue d'A'thenes, Paris, France.

Hackney. Hackney Stud Book. Hackney Horse Soc'y, Frank F. Euren, Sec'y., 12 Handover Sq., London, W. England.

Shetland Pony. Shetland and Pony Stud Book. Shetland Fony

Percheron. Studbook Percheron de France. La Societe Hippique: Percherrone de France, E. Lemarie, Sec'y., Noget le Rotrou, France.

Studbook Society, R. W. Walker, Sec'y., 3 Golden Sq., Aberde $\in$ n, Scotland.

Shire. Shire Horse Society Studbook. Shire Horse Soc'y, J. Sloughgrove, Sec'y, 12 Handover Sq., London, W., England.

Suffolk. Suffolk Studbook. Suffolk Horse Soc'y, Fred Smith, Sec'y, Rendelsham, Woodbridge, Suffolk, England.

Thoroughbred. Australian Studbook. W. C. Yuille \& Sons, MeIbourne, Aus. General. Studbook. Weatherby \& Sons, 6 Old Burlington St., London, W., England.

Welsh Pony \& Cob. Welsh Pony \& Cob Studbook. The Welsh Ponk \& Cob Soc'y, John R. Bache, Sec'y., Knighton, Radnorshire, Wales.

Belgian Draft. Canadian. Canadian Nat'1. Records, Secretarya; Ottawa, Canada. Records.

Clydesdale, Hackney, Shire, Suffolk, Welsh Pony \& Cob. Nationas

The stud books and signatures of the duly authorized officers of the following American horse and jack pedigree registry association, societies or companies, certified by the Department of Agriculture, Washington, D. C., in Bureau of Animal Industry, Order No. 136 June 20, 1906, and in the amendments thereto:

"B"

Name of breed, book of record, and by whom published.

Arabian. Studbook of the Arabian Horse Club of America. Arabian Horse Club of America, H. K. Buch-Brown, Sec'y, Newburgh. N. Y.

Belgian Draft. American Register of Belgian Draft Horses... American Association of Importers and Breeders of Belgian Drafti. Horses, J. C. Connor, Jr., Secretary, Wabash, Ind.

Cleveland Bay. American Cleveland Bay Sírd Book. Cleveland Bay Society of America, R. P. Stericker, Secretary, Oconomowoc, Wis.

French Draft. National Register of French Draft Horses. National French Draft Horse Association of America, C. E. Stubbs Secretary, Fairfield, Iowa.

Clydesdale. American Clydesdale. American Clydesdale Association, R. B. Ogilvie', Secretary, Union Stock Yards, Chicago, III.

French Coach. French Coach Studbook. French Coach Hors Society of America, Duncan E. Willetst, Secretary, Maple Avenue ancie Harrison St., Oak Park, Ill. 
French Coach. French Coach Horse Register. French Coach Horse Reg., C. Glenn, Secretary, 1319 Wesley Ave., Columbus, Ohio.

German Coach, Oldenburg. German Hanoverian and Oldenburg Coach Horse Studbook. German Hanoverian and Oldenburg Coach Horse Association of America, J. Crouch, Secretary, Lafayette, Ind.

Hackney. American Hackney Studbook. American Hackney Horse Society, Gurney C. Gue, Secretary, 308 W. 97th St., New York City.

Jácks and Jennets. American Jack Stock Studbook. American 'Breeders' Association of Jacks and Jennets, J. W. Jones, Secretary, Columbia, Tenn.

Percheron. Percheron Studbook of America. Percheron Society of America, Wayne Dismore, Secretary, Union Stock Yards, Chicago, Illinois.

Percheron. Percheron Register. The Percheron Registry Company, Chas. C. Glenn, Secretary, 1319 Wesley Ave., Columbus, Ohio.

Percheron. The American Breeders' andi Importers' Percheron Register. The American Breeder's' and Importers' Percheron Registry Company, John A. Forney, Secretary, Plainfield, Ohio.

Shesland Pony. American Shetland Pony Club Studbook. Ameracan Shetland Pony Club, Miss Julia M. Wade, Secretary, LaFayette, Indiana.

Shire. American Shire Horse Studbook. American Shire Horse Association, Chas. Burgess, Sr., Secretary, Wenoa, Ill.

Suffolk. American Suffolk Horse Studbook. American Suffolk Horse Association, Alex Galbraith, Dekalb, Ill.

Thoroughbred. American Studbook. The Jockey Club. W. H. Rowe, Registrar, 571 Fifth Avenue, New York, N. Y.

Welsh Pony and Cob. Welsh Pony and Cob Studbook . The Welsh Pony and Cob Society of America, John Alexander, Secretary, Aurora, Ill.

American Trotier. American Trotting Register. American Trotting Register Association, Wm. H. Knight, Secretary, 137 So. Ashland Boulevard, Chicago, Ill.

Morgan. American Morgan Register. American Morgan Register Association, T. E. Boyce, Secretary, Middlebury, Vむ.

Saddle Horse. American Saddle Hor'se Register. American saddle Horse Breeders' Association, I. B. Nall, Secretary, Louisville', 副y.

The said Stallion Registration Board shall accept as pure bred entitled to a license certificate as such, each stallion or jack for which a pedigree registry certificate is furnished the inspector bearing the ssignature of the duly au'vhorized officers of one of the above named associations, societies or companies.

SEC. 3. CERTIFICATE FORN-The certificates for stallions shall be of two forms, one for pure breds, and one for grades. Each certificate shall state the name of the stallion or jack and if pure bred and registered number and the name of the stud book in which such stallion or jack is registered. Each certificate shall bear the name of the importer or breeder, the name of the present owner, * $x$ description of the color, the year foaled and inspector's statement : as to whether said stallion or jack is sound or unsound. If unsound the certificate shall contain the names of the diseases, the location of which shall be indicated by means of a small diagram of a stallion एproperly marked by the inspector. Each certificate shall bear the signatures of the Inspector and secretary of the Stallion Registra- 
tion Board, and shall have attached thereto the official seal of saic: Board. A grade shall be defined as a stallion or jack whose owner presents the affidavit of two persons that said grade has either a. sire or dam of pure breeding.

SEC. 4. QUALIFICATIONS. No stallion or jack which may come into the state of Nebraska, after this act shall take effect, shall be given a cerifificate if such stallion or jack is affected with one or more of the following diseases, namely: urethal gleet, melanosis, periodic opthalmia (moonblindness), laryngeal hemiplegia (roaring), cataract, amaurosis (glass eye), chorea iSt. Vitus dance), string halt, bone spavin, bog spavin, ring bone, side bone, curb with curly formation of hock or is seriously defective in conformation, with vicious disposition.

SEC. 5. RE-EXAMINATION. Every stallion or jack whic'? has been granded a certificate by the Stallion Registration Board shall be re-examined by an authorized veterinarian each year thereafter and said board shall have the power to revoke certificates for cause... Exceptions: Stallions over eight years of age having had three prior annual sound certificates from this board shall be exempt from further examinations, except for contagious or infectious disease, upnn. display of age certificate issued by the Stallion Registration Board, age to date from Jaunary 1 of the year of its birth. Every certificate except "Transfer" shall be for the calendar year. Colts less than eighteen months old are not classified as stallions and are not: subject to inspection except by request of owner or agent.

SEC. 6. CERTIFICATE POSTED. Eevry owner or keeper of a stallion or jack kept for services shall keep posted the certificates issued by the Stallion Registration Board or a copy of the same, during the entire breeding season, in a conspicuous place within every shed or building in which such stallion or jack is kept for service.

SEC. 7. ADVERTISEMENTS. No owner or keeper of a stallion not of pure breeding shall permit the printing, publishing or circulating of any bill, poster, card, newspaper advertisement or other advertisement calling attention to said stallion as a breeder, unless the same shall have the words "grade stallion" in two inch type immediately preceding such name.

SEC. 8. RECORD OF CERTIFICATE. It shall be the duty of the Stallion Registraition Board to keep a record of all certificates and the issuance. refusal or revocation of the same.

SEC. 9. CERTIFICATE TRANSFER. If the owner of the: stallion or jack shall sell, exchange, or transfer the same, said Stallion Registration Board shall, upon receiving the certificate in force at the time of the sale and satisfactory proof of such change in ownership, issue to the new owner a certificate of transfer of ownership.

SEC. 10. FEES. A fee of Three Dollars (\$3.00) shall be paid for each certificate, for each renewal Three Dollars $(\$ 3.00)$, for each transfer of ownership twenty-five cents (25c), and two dollars: (\$2.00) for age certificate. If the owner or lessee of any stallion or jack after due notification by the Stallion Registration Board, fails to deliver said stallion or jack for inspection in all cases on the day and at the place designated by the Stallion Registration Board, the : fees of such inspection may, in the discretion of the Board, be doubled.. The inspection as far as practical shall be made at the place where stallions or jacks are kept.

SEC. 11. FUNDS, HOW USED. The funds accruing from registration shall be used by the Stallion Registration Board for printing, office supplies, secrevary and clerical service, payment of inspectors, and the publication of an annual report which shall contain an alphabetical list of stallions and jacks which have been granted. 
sercificates and a full and complete account of all money received and expended.

SEC. 12. VIOLATION OF ACT, PENALTY. Any person, firm or corporation who shall violate any of the provisions of this act shall be guilty of a misdemeanor and be punished by a fine of not less than fifty dollars $(\$ 50.00)$ nor more than one hundred (\$100.00) dollars or be imprisoned in the county jail not exceeding thirsy (30) days, or both such fine and imprisonment, in the diseretion of the court.

SEC. 13. CERTIFICATES HERETOFORE ISSUED. All 1913 inspections made and certificates issued by the Nebraska Stallion Registration Board, W. R. Mellor, Secretary, are hereby ordered recognized as valid for the current year, by this Board hereby created.

SEC. 14. REPEALS. Thav' sections 3302, 3303, 3304, 3305, and 3306 of Cobbey's Annotated Statutes for 1911 (Compiled Statutes Chapter 4, Sections $40 \mathrm{a}-\mathrm{e})$, as the same now exists, are hereby repealed.

The following is a copy of the certificate that will be issued for soure bred stallions, and similar certificates will be issued for grade stallions, and jacks:

\section{State of Nebraska \\ Stallion Registration Board \\ License Certificate No. \\ Pure Bred Stallion}

The pedigree of the stallion.

Bred by

P. O.

State

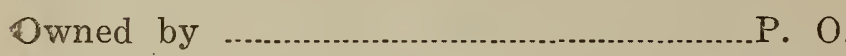

Foaled .......................................... Weight. Neb.

has been examined by the stallion Registration Board and it is hereby certified that the said stallion is of pure breeding and is registered as No. in the Stud Book recognized by statute (Chapter 1, Laws of Nebraska, 1913). The above named stalIion has been examined by a qualified veterinarian who reports as follows :

"I have this diay examined the pure bred stallion named.

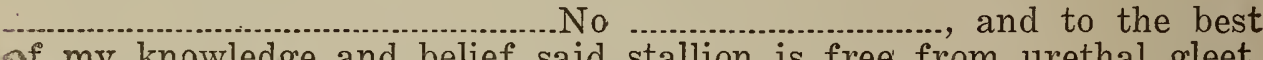
of my knowledge and belief said stallion is free from urethal gleet, melanosis, periodic opthalmia, laryngeal hemoplegia, and serious defects in general conformation. I further certify that said stallion is sound except as indicated in the diagram below."

(Diagram of Horse Here.)

State Stallion Inspector.

Said stallion is hereby licensed to stand for public service in the State of Nebraska during the season of the calendar year 19.

Dated at Lincoln, Nebraska, this. day of. 19

Nebraska stullion Re'gistration Board. 


\section{Hudson and}

\section{Greenameyer}

\section{... Live Stock ... \\ Commission \\ Merchants}

Note: Our Shippers are Our Best Advertisers

A. G. Greenameyer, Bert Carpenter, O. J. Gibbs, Cattle Salesmen
W. C. Hudson,

Jno. Griggs, Hog Salesmen .

Auto. Phone 1227

Iowa Phone 755

'Room 210 Exchange Bldg. Sioux City, lowa. 


\section{Long \& Hansen Commission Co.}

\section{Sioux City Stock Yards}

Ship Your Live Stock

$$
\text { .... to... }
$$

Long \& Hansen Comm. Co. $\ldots$ and secure ...

Quickest Returns Lightest Shrinkage Best Results

Our Customer's Interest is Our Interest

You are cordially invited to visit Our offices at any time

Long \& Hansen Comm. Co. Sioux City, - - - Iowa 


\section{Criminal-Animals}

\section{HOG STEALING.}

If any person or persons shall steal any sow, barrow, boar, or pig of any value, or if any person shall receive or buy any sow, barrow, boar, stag or pig that shall have been stolen, knowing the same to have been stolen, with intent by such receiving or buying to defraud the owner, or if any person shall conceal any such thief knowing him to be such or if any person shall conceal any sow, barrow, boar or pig, knowing the same to have been stolen, every such person so offending shall be imprisoned in the penitentiary not more than five nor less than one year and shall pay the costs of prosecution.

HORSE STEALING, RECEIVING OR BUYING STOLEN HORSE -CONCEALING SUCH HORSE, OR A HORSE THIEF.

If any person shail steal any horse, mare, geiaing, foal or filly. ass or mule of any value; or, if any person shall receive or buy any horse, mare, gelding, foal or filly, ass or mule, that shall have been stolen, knowing the same to have been stolen, with intent, by such receiving or buying, to defraud the owner; or, if any person shall conceal any horse thief, knowing him to be such; or, if any person shall conceal any horse, mare, or gelding, foal or filly, ass or mule, knowing the same to have been stolen; every person so offending shall be imprisoned in the penitentiary not more than ten nor less than one year.

\section{STEALING AND RECEIVING STOLEN CATTLE.}

If any person or persons shall súeal any cow, steer, bull, heifer, or calf, of any value, or if any person shall receive or buy any sow, steer, bull, heifer, or calf, that shall have been stolen, knowing the same to have been stolen, with intent by such receiving or buying to defraud the owner, or if any person shall conceal any such thief, knowing him to be such, or if any person shall conceal any cow, steer, bull, heifer, or calf knowing the same to have been stolen, every such person so offending shall be imprisoned in the peitentiary not more than ten years nor less than one year, and shall pay the costs of the prosecution.

\section{TAKING HORSE OR MULE WITHOUT LEAVE.}

If any person shall wrongfully take any horse, mare, gelding, foal, or filly, ass, or mule, from the stable, lot or pasiure of another, or from a hitching rack, or any other place as aforesaid, having been lawfully placed, without consent of the owner, with intent to injure, set at large, or wrongfully use the animal so taken, such person shall be fined in any sum not exceeding one hundred dollars or be imprisoned in the county jail not exceeding three months, in the discretion of the court, and shall also be liable to the party injured in double the amount of damages sustained.

\section{MUTILATION OF HORSES.}

Whoever cuts the bone of the vail of any horse for the purpose of docking the tail, or whoever causes or knowingly permits it to be done upon premises of which he is the owner, lessee, proprietor or user, or whoever assists in such cutting shall be punished by imprisonment in the county jail not exceeding one year, or by fine of not less than one hundred dollars nor more than three hundred dollars.

\section{KILLING OR INJURING ANIMALS.}

If any person or persons shall wilfully and maliciously kill or destroy any horse, mare, foal, filly, mule, ass, sheep, goat, cow, ox, steer, bull, heifer or swine, the properiy of another or others, of the value of thirty-five dollars or upward, or shall wilfully and malicionsly injure any such animal or animals, the property of another 
or others of the value of thirty-five dollars or upwards, the person or persons so offending shall be imprisoned in the penitentiary not more than three years nor less than one year.

\section{POISONING ANIMALS WITH INTEN'T TO INJURE OR DE- STROY THEM.}

(a) If any person or persons shall wilfully and maliciously administer, or cause to be administered, poison of any sort whatever, to any horse, mare, foal, filly, jack, mule, ass, sheep, goat, cow, or steer, bull, heifer, or swine, the property of another, with intent to injure or destroy such horse, mare, foal, filly, jack, mule, ass, sheep, goat, cow, ox, steer, bull, heifer or swine, the person or persons so offending shall be fined in the sum of one hundred dollars or imprisoned in jail of the proper county, not exceeding thirty days, at the discretion of the court.

\section{CRUEL TREATMENT OR EXPOSURE OF DOMESTIC}

\section{ANIMALS.}

(b) Any person or persons who shall wilfully, inhumanely or unreasonably beat, strike, kick, wound, maltreat or maljciously kill any horse, mule, cow, ox, sheep, swine or poultry or any other animal enumerated as domesticated animals, or shall pick the feathers from any live fowl or poultry, preparatory to killing or dressing the same, or any person or persons, whether the offender be owner, agent or servant, who allows his horse, mule, pony or team, whether horses, mules or oxen, to stand tied upon the street or public highway for two hours at a time in cold or stormy weather to the injury of said animal or animals shall upon conviction thereof be fined in any sum not less than five nor more than fifty dollars.

\section{ABUSING OR OVERWORKING ANIMALS.}

(c) Any. person or parsons who shail overdrive, abuse, overload or overwork any horse or horses, mule or mules, or oxen, or unnecessarily torture or tormeni any domestic animal shall, upon the conviction of any of the offenses enumerated herein, be deemed yuilty tof a misdemeanor, and shall be punished as hereinafter provided.

\section{SHELTER.}

(d) Any person or persons, whather as owner or agent h iving in charge horses, mules, cattle, sheep or swine, or any other domesticated animal or animals commonly called live stock, who shall wilfully or carelessly neglect to provide sufficient sustenance or shelter therefor, at any season of the year, shall upon, the conviction ve deemed guilty of a misdemeanor, and upon conviction thereof shall be punished as hereinafter provided.

\section{ARREST OF PERSONIS VIOLATING.}

I $i$ is hereby male the duty of sheriffs, constables, marshals of cities or villages, or police officers to immediately arrest any person or perions violating any of the provisions of the foregoing sections of this act, without warrant or process, and call upon bystanders or others for assisiance when the same may be necessary to enable them to make such arrest. Any person who. shall violate any of the provisions of this act ( $a, b, c$, and d), shall for each offense be fined in any sum not less than five dollars $(\$ 5)$ nor more than fifty dollars $(\$ 50)$.

\section{CRUELTY TO ANIMALS.}

Any person who shall impound or cause to be impounded, in any pound or yard, for sale or slaughter, or for any otiner purpose, any domestic animal, shall supply the same during such confinement with a sulficient quantity of good and wholesome food and water, and in default thereof shall upon conviction, be adjudged guilty af a misdemeanor, and in case any domestic animal shall be at any 
time impounded or yarded, as aforesaid, and shall continue io be: without necessary food and water for more than twenty-four successive hou"s, it shall be lawful for any person, from time to time and as often as it shall be necessary, to enter into and upon any pound or yard in which any such dcmestic animal shall be so confined, and to supply it with necessary food and water so long as it shall remain so confined. Such person shall not be liable to any. action for such entry, and the reasonable cost for such food and water may be collected by him of the owner of such domestic animal, and the said domestic animal shall not be exempt from levy. and sale. upon the execution issued upon a judgment therefore.

\section{ABANDONING SICK OR DISABLED ANIMALS.}

If any maimed, sick, infirm or disabled domestic aniaml shall ber abandoned to die by any person, such person shall be deemed guilty of a misdemeanor, and upon conviction thereof shall be fined in any sum not less than five nor more than fifty dollars. It shall be lawfuI for any magistravic or peace officer to appoint suitable persons to. care for and, if necessary, to destroy such animal; any expense for such care or disposing of such animal to be a charge against and collectable from the owner. by the party incurring the same.

Ed. Note: The penalty for violation of this and the preceding law is a fine of from five to fifty dollars.

\section{BULL-BAITING AND TORTURE OF ANIMALS.}

Any person or persons who shall confine, or aid or assists in confining any bull, steer, or other domestic or domesticated animal or animals, either by tying, penning or enclosing the same for the purpose of bull-baiting, bear-baiting or other purpose of torture, or shall aid or assist in torturing the same when so tied or penned, either by dogs, whips, spears or other instruments, shall pay a fine: not exceeding one hundred dollars.

\section{HORSE RACING.}

If any two or more persons shall run a match, horse race or races in any public road in common use, 'for the purpose of trying. the speed of their horses, every person so offending shall be fined in. any sum not exceeding five dollar's nor less than one dollar.

\section{BREAKNG OPEN OR INJURING POUND.}

It is hereby declared unlawful for any person or persons to. interfere with or set at liberty any domestic animal or animals impounded in a lawful manner by any other person; and every person. so offending shall, upon conviction thereof pay a fine not exceeding. one hundred dollars nor less than five dollars.

FALSE STOCK PEDIGREE.

If any person shall knowingly, and with intent to deceive, furnish to any purchaser of stock a printed or written false pedigree of the same, whereby such purchaser shall be induced to buy said stock, the person so offending shall be guilty of a misdemeanor, and on conviction thereof be punished by a fine of not less than twenty-five dollars nor more than two hundred dollars, or by imprisonment in the county jail not less than three nor more than six months, orby both fine and imprisonment, as the court may direct.

\section{Fence Laws}

While the fence laws of the state are not strictly speaking "stock laws," still they have a close application thereto, and for that reason it is deemed advisable to give them in a brief form. Materially they are as follows:

\section{LAWIFUL FENCE.}

Any structure or hedge or ditch in the nature of a fence, used. 
Tor the purposes of enclosure which is such as good husbandmen generally keep, is deemed in law to be a lawful fence.

If the fence is a rail fence it shall consist of at least six rails, secured by stakes at the end of each panel, well set in the ground, with a rider upon the stakes.

A board fence shall consist of not less than three boards of at Ieast five inches in width and one inch thick; well secured to posts, such posis not to be more than eight feet apart.

A rail and post fence shall consist of at least three rails, well secured at each end to posts and the posts must not be more than ten feet apart.

A pole and post fence musts consist of not less than four poles, well secured to posts and the posts are not to be more than seven feet apart.

A wire fence must consist of at least four wires of such size not less than number nine fence wire, well secured to posis and the posts must not be more than one rod apart, with a stake or post between every two posts to which the wire shall be atuached.

All the above fences must be at least four and one-half feet in height and the spaces between the boards, rails, poles and wires of such fences shall not exceed one foot each, measuring from the top.

A hedge fence of sage orange shall consist of at least one row of plants not more than eight inches apart at the surface of the ground and shall be such as the fence viewers shall decide a lawful fence. A hedge fence of willow or other trees shall consist of at least one row planted not more than fifteen inches apart at the surFace of the ground and at least two and one-half inches in diameter, "and at least six feet in height.

"Warner's patent" fince shall be at least four and one-half feet high, and of not less than five boards at least five inches wide and one inch thick. .

\section{LIVE FENCES.}

The owner or occupiei of lands bordering upon a public road or highway, except a street or alley in a town, may plant and cultivave any hedge, or live fence, along the margin of their land, but such fence must be set directly in line with the road, with a protection fence, and shall not occupy more than six feet of the margin or edge of sair road and such protection fence, when placed opposite to any live fence or hedge, shall be permitived to remain for the term of seven years; provided that the county commissioners may grant permission in writing to the owner to continue such protection fence any term of time which they may deem necessary. This does not apply to railroad companies.

\section{PARTITION AND DIVISION FENCES.}

It has been held that where a person constructs a division fence without complying with the statu's he can not have contribution from the owner of adjoining land, hence it is essential that the following provisions be complied with in order that each party's rights may be protected:

When two or more persons have adjoining lands, each of them shall make and maintain a just proportion of the division fence beIween them, except the owner of either of the adjoining lands shall choose to let his lands lie open, but should he afterwards enclose his lands then he must pay a just proportion of the value, at the time, of any division fence sinat shall have been made by such adjoining owner, or he shall immediately build his proportion of such division fence.

The value of such division fence and the proportion to be made and maintained by him in case of his enclosing his land, shall be 
determined by any two fence viewers of the precinct, in the county, and all disputes arising concerning the proportion of fence to be made or maintained by either party shall be settled by the fence viewers of the county; and in such case it shall be the duty of the fence viewers to distinctly mark and define vine proportion of the fence to be made or maintained by each.

These fence viewers are selected as follows: Each party shall choose one, and if either party neglect, after eight diays' notice to make such choice then the other party may select both. The fence viewers have power to subpoena, administer oaths to, and examine witnesses on all questions submitted to them. Justices of the peace are ex-officio fence viewers of the county. The fees of the fence viewer's are one dollar pei day each, for the time necessarily spent, payable in the first instance by the party requiring their service; and all expenses of the view shall be borne equally between the parties, except in case of view to appraise damages for neglect or refusal to make or maintain a just proportion of the division fence, in which case the cost of view shall be paid by the party in default, and may be recovered as a part of the damage assessed in a civil action in any court of this staive.

Upon choosing of the viewers they shall proceed to examine the premises and hear the allegations of the parties; in case of their disagreement, they shall select another fence viewer to ac's with them, and the decision of any two of them shall be final upon the parties to such disputes and upon all parties holding under them. Their decision shall be made in writing; shall contain a descripition of the fence, of the proportion to be maintained by each, and their decision upon any of the disputed points submitted to them shall be filed immediately in the office of the county clerk.

Should any person who is liable to contribute to the erection or reparation of a division fence neglect or refuse for the period of four weeks after notice in writing, to make and maintain his proportion of the fence, the party injured may make or repair the same at the expense of the party neglecting or refusing and can be recovered from such party with cost of suit. The neglecting party is also liable for all damages caused by such neglect or refusal determinable by any two fence viewers selected as above provided-their appraisemenis of such damage to be reduced to writing and properly signed.

\section{REMOVAL OF DIVISION FENCE.}

Any person who has made his proportion of a division fence can remove such proportion after giving the adjoining owner at least sixty days' notice in writing of his intention to dio so, but such fence can only be removed between the first day of December and the firsts day of April and at no other time of the year. If such fence is removed without such notice the party removing the same shall pay to the injured party all damages the injured party has suffered, to be recovered with costs of suit.

\section{DIVISION FENCE DESTROYED BY CASUALTY.}

Should a division fence be injured or destroyed by fire, flood or any other casualty the person bound to make and repair such fence, or any part of it. shall make or repair the same, or his just proporivon thereof, within ten days after he shall be thereto required by any person interested therein, such notice to be in writing and signed by party making the same. Should he neglect or refuse to do so for a period of ten days after such written request the party injured may make or repair the fence at the expense of the party refusing or neglecting and such amount can be recovered with cost of suit. 


\section{REMOVAL OF FENCES, FOR PUBLIC ROAD.}

Whenever a public road is ordered to be established or altered, which road shall pass through or on inclosed lands not planted or sowed with crops, the road overseer shall give the owner or occupant of such land six and upon the failure of the owner so to do the overseer shall cause the same to be removed and the road opened and worked and the owner shall forfeit the sum of one dollar for every day he permits his fence to remain after the expiration of the sixty days, and pay all necessary cost of removal, to be collected by the overseer before any justice of the peace of competent jurisdiction.

INJURING FENCES, GATES, ETC. (Criminal.)

Any person who shall wantonly or maliciously throw, put, or lay down, prostrate, deface or injure any fence enclosing an orchard, pasture, meadow, garden, yard or other field or inclosure, the property of, or lawfully occupied by any other person or persons, or corporation, or shall wantonly or maliciously open, let down, throw down, prostrate, injure or deface any gate, or bars belonging to any such inclosure, every such person shall be find in any sum not exceeding one hundred dollars, or be imprisoned in the jail of the county not exceeding thirty days, or both, at the discretion of the court.

\section{RAILROAD FENCES-NOTICE TO FENCE.}

Every railroad corporation whose lines of road or any part thereof are open for use shall erect and maintain fences on the sides of their roads, or the part of their road open for use, such fences to be suitably and amply sufficient to preven's stock from getting on the right of way, except at the crossings of public roads and highways and at farm crossings, openings or gates or bars, for the use of the proprietors of the lands adjoining such railroad shall be established. There shall also be established at all road crossings, cattle guards suitable and sufficient to prevent stock from getting on the right of way of such railroad corporation and its agents shall be liable for all damages to stock by the agents, engines, or trains of such railroad and those of any other railroad companies permitted to run on their railroad.

Should such fences and guards be kept in good and sufficient repair, such railroad company shall not be liable for damages, unless negligently or willfully done.

Any person owning land adjoining the right of way of any railroad company who intends to enclose his land, or any part of it, that adjoins the railroad, may notify in writing the railroad company of his intention, and request the railroad company to build a "lawful fence" on the line between their railroad and the land intended so be enclosed. Such notice shall definitely specify two points on such land between which points such fence is requested to be erected, and describe the field intended to be enclosed. The railroad company shall, within six months after receiving such notice, cause to be erected the fence required by such notice, and in case of a failure so to do, the party so giving the notice may cause such fence to be erected at a reasonable cost, and collect the amount thereof from the railroad company.

\section{Stock Yards}

DEFINITION OF TERMS-STOCK YARD INCLUDES.

The term stock yards as used herein shall mean and embrace all corporations, individuals, associations of individuals, their lessees, trustees or receivers (appointed by any court of lawful authority whatsoever) that now or hereafter may own, operate, manage or control any yards and pens, railroad tracks, switches, engines or 
other motive power, for the purpose of handling live stock in transit and for sale and all stock yards are hereby declared to be common carriers.

\section{STATE RAILWAY COMMISSION CONTROL.}

The State Railway Commission shall have power to issue orders regulating service and charges of all kinds at all stock yards, and the same shall be enforced in the same manner and under the same penalties as orders regulating common carriers, provided, that where no other penalty is provided by law for a violation of any such order, it shall be punishable by a penalty of not less than one hundred dollars, nor more than five hundred dollars, and where the violation is a continuing one, each day thereof shall constituse a separate offense.

\section{UNLOAD IN TWO HOURS-PENALTY.}

Every stock yards shall handle, unload and yard all cars of live stock arriving between the hours of 6 o'clock a. m. and 6 o'clock p. m. and deliver into yards used by commission company, when so requested, within two hours after the final delivery of the same at the tracks of said stock yards by the connecting railroad, except in cases of unavoidable delay or unusual circumstances. For each half hour's delay in handling and unloading live stock beyond the period prescribed herein any such stock yard shall forfeit and pay to the shipper of said live stock or his agent, as demurrage, within twenty-four hours after unloading said live stock, the sum of five dollars for each car of live stock so delayed. Said payment to be made by mailing draft or certified check to agent or owner. Provided, that if any part of the forfeitures described in this section shall be collected by a suit at law an aitorney's fee of five dollars per car shall be allowed the plaintiff by the court, but not exceeding fifteen dollars on any one shipment.

\section{RECORD OF STOCK HANDLED.}

Every stock yard shall keep a record showing the time of de. livery and turning over at the yard of said stock to the commission firm, agent or owner.

\section{FURNISH SCALES AND YARDS.}

Every stock yard shall furnish scale facilities sufficient to weigh all live stock without unreasonable delay. It shall furnish yardage to handle all live stock in yards and no charge shall be made for yardage where yards are not furnished.

\section{Liens on Live Stock-Miscellaneous}

\section{LIEN FOR KEEPING FORECLOSED-AFFIDAVIT FILED.}

When any person shall procure, contract wioh, or hire any other person to feed and take care of any kind of live stock, the person so procured, contracted with or hired, shall have a lien upon such property for the feed and care bestowed by him upon the same for the contract price therefor, and in case no price has been agreed upon, then the reasonable value of such feed and care. The person entitled to lien under the provisions of this section may foreclose the same in the manner provided by law for the foreclosing of the chattel mortgages; Provided, that at least shirty (30) days before the sale of the property for the satisfaction of such lien, the person entitled there's, shall file in the office of the county clerk in the county in which said live stock may be fed and kept, an affidavit describing said live stock, and setting forth the amount justly due for the feeding and keeping of the same. 


\section{Registering}

\section{REGISTERING NAME OF RANCH OR HOME.}

That hereaftser the owner of any farm, ranch or home may upon the payment of one dollar $(\$ 1.00)$ to the county clerk of the county in which said farm or ranch is located be entitled to have the name of his farm, ranch or home duly recorded in a register to be kept by the couni'y clerk for said purpose and shall further be entitled to a certificate, under the seal of said office, setting forth the name of said farm, ranch or home, its description by the United Staves survey thereof, and name of owner. Provided, that when any name of such a farm, ranch or home has been so recorded said name shall not be recordied as the name of any other farm, ranch, or home, in the same county unless plain designation of words are prefixed, affixed or both prefixedj and affixed thereto. Provided further, that upon the recording of a certified transfer of such name by the owner of said farm, ranch or home, said certified transfer shall be made an additional part of the records so kept.

\section{Execution}

\section{ALLOWANCE FOR KEEPING LIVE STOCK.}

When any cattle or other live stock shall be taken in execution it shall be the duty of the justice who issued the execution, or other justice charged with the duty of collecting the judgment whereon such execution issued, to allow the officer, for keeping the same, a reasonable compensation, to be taxed and collectedi as other costs in the suit.

\section{Taxes}

\section{STOCK IN CHARGE OF AGENT.}

Live stock in charge of an agent, care taker or non-resident owners, on the first day of April of the year for which the property is required to be listed, and not connected with the farm, shall be assessed where so kept; and any live stock which shall be brought into any county of this state for grazing purposes between the first day of April and the first day of July of any year shall be assessed by the assessor or by the county board in such county and in the proper taxing district, unless the owner of said live stock produce a certificate from the county clerk, or other proper officer, showing that such property has been assessed elsewhere.

\section{Cruelty to Animals}

\section{CRUEL OR INHUMANE TRANSPOITATION OF ANIMALS.}

If any person shall carry or cause to be carried, in or upon any vehicle or otherwise, any domestic animal in a cruel or inhuman manner, he shall be deemed guilty of a misdemeanor, and whenever he shall be taken into cusiody therefor by any officer such officer may take charge of such vehicle and its contents, and deposit the same in some safe place or custody; and any necessary expenses which may be incurred for taking charge and keeping and sustaining the same, shall be a lien thereon, to be paid before the same can be lawfully recovered, and if the said expenses or any part thereof, remain unpaid, they may be recoverd by the person incurring the same of the owner of said domestic animal in any action therefor; and it shall be unlawful for any person or corporation engaged in transporting live stock on railway trains to detain such stock in cars for a longer continuous period than twenty-four hours without supplying the same with food and water. 


\section{Iowa Laws}

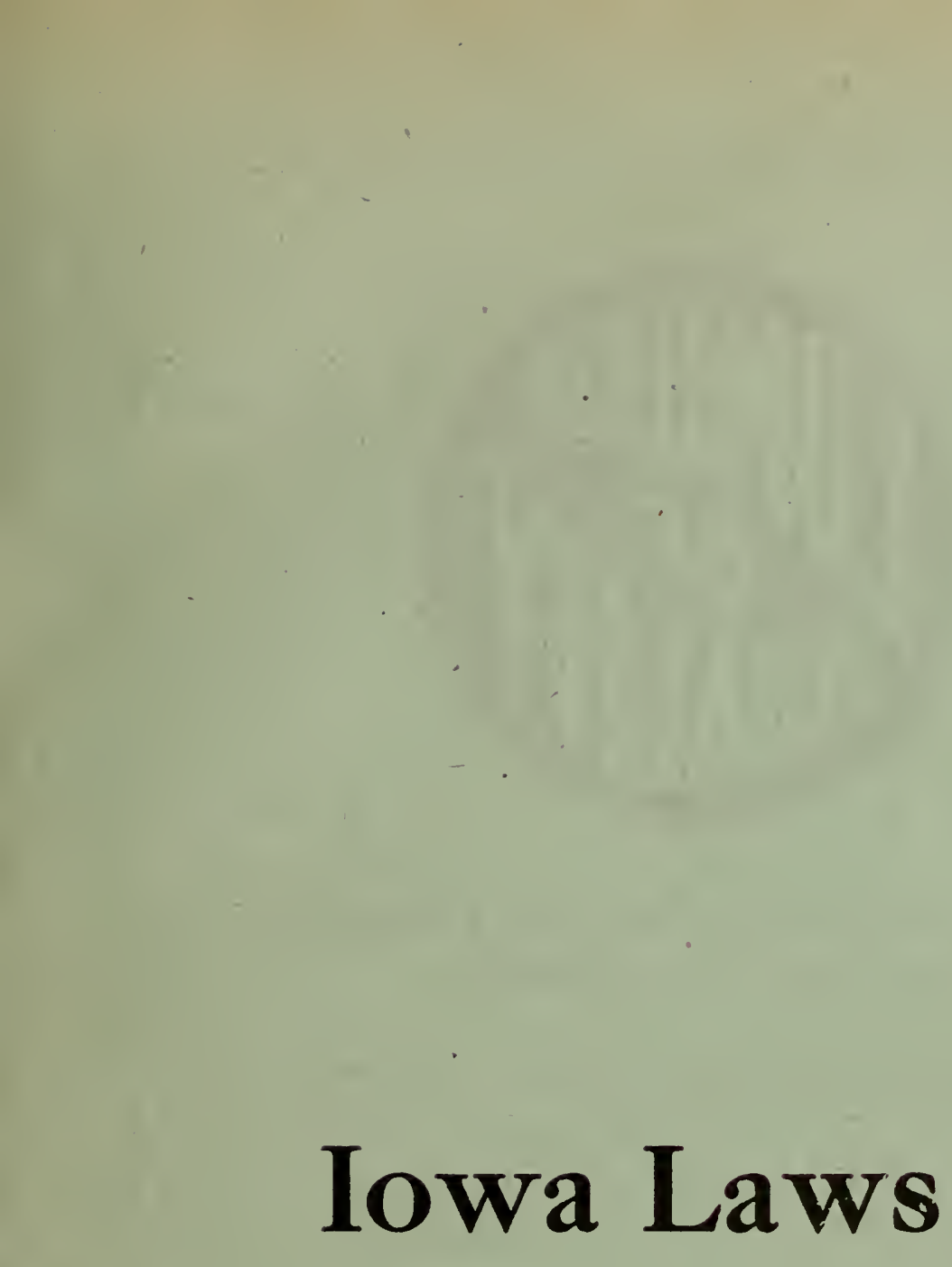

Laws 


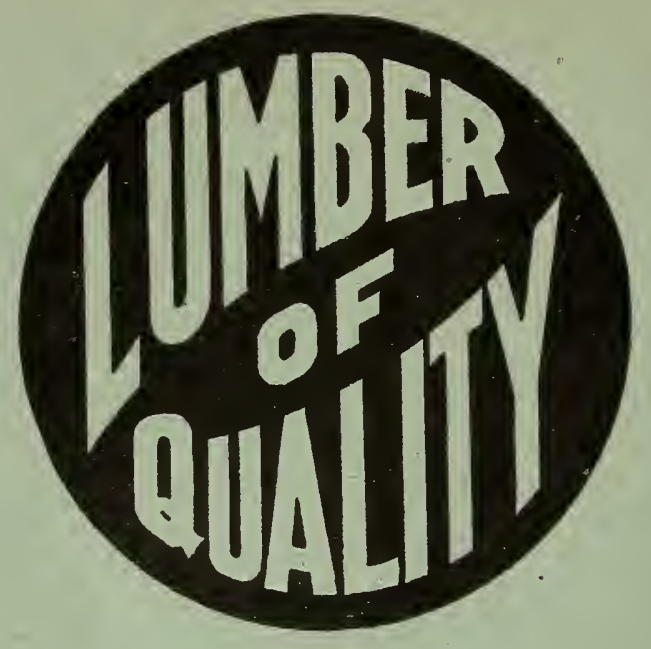

q We operate a line of retail Lumber Yards in North East Nebraska.

qWe manufacture a greater part of the lumber we sell, at our own mill at Elk, Washington. We maintain buying offices at Seattle, Washington and Shreveport, Louisana.

qTherefore we are in position to sell you lumber as cheaply as you can buy it anywhere. Our yards are scattered thickly over North East Nebraska-you can't miss us-and our motto is

QUALITY-SERVICE-PRICE

\section{Edwards \& Bradford Lumber Co.}

Sioux City, $\quad-\quad \quad-\quad \quad-\quad$ Iowa 


\section{IOWA LAWS}

\section{Stallions, Jacks and Registered Pedi- greed Stock}

SECTION 1. ENROLLMENT-ANNUAL CERTIFICATES OF SOUNDNESS-FEE. No person, firm, company or corporation shall offer for public service, sale, exchange or transfer in this state as registered any stallion or jack over two years old unless and until he shall have caused the name, age, color and pedigree of the animal to be enrolled by the secretary of the state board of agriculture and shall have procured from him a certificate of such enrollmenis. The secretary of the state board of agriculture shall recognize as registered only such animals as have been recorded in some stud book recognized by the department of agriculture of the state of Iowa, and the cerivificate of pedigree shall accompany the annlication for enrollment. The state of Iowa shall be paid the sum of one dollar for each annual certificate of soundness issued by the secretary of the state board of agriculture, according to the methods hereinafter provided.

SEC. 2. OATH OF OWNER OR KEEPER OR CERTIFICATE OF VETERINARIAN. The owner or keeper cf each and every sillion or jack over two years old kept for public service, sale, exchange or tran $\approx$ fer shall cause said stallion or jack to be examined by a duly qualified veterinarian, who shall be a graduate of a recognized college and registered as graduate veterinarian by the Iowa board of veterinary examiner's, or veterinarian, licensed by said board, who shall make affidavit that such animal is free from hereditary, infectious, contagious or transmissible disease or unsoundness, and shall file the same with the secretary of the state board of agriculture. Any veterinarian who knowingly or wilfully makes a false report upon the disease or freedom from disease, or soundness or unsoundness of the animal brought to him for examination shall be punished by the revocation of his veterinarian certificate. The owner or keeper of each and every stallion or jack over two years old kept for public service or for sale, exchange or transfer shall between the dates of January first (1) and April first (1), of each year after their first registration make application for the renewal of the certificate in the form and manner as above described.

SEC. 3. DISQUALIFICATIONS. The presence of any one of the following named diseases shall disqualify a siallion or jack for public service and no certificate shall be issued by the secretary of the state board of agriculture: G'anders, farcy, malajie ducoit, coital exanthema, urethral gleft, mange, melanosis, blindness, cataract, bone spavin, ringbone and periodic opthalinia (moon blindness). Siallions or jacks possessing any of the following named unsoundnesses may receive a certificate, but each certificate and every advertisement shall state in large type or writing that the stallion or jack is unsound and shall specify ine unsoundness or unsoundnesses which said stallion or jack has: Amaurosis, laryngeal hemiplegia (roaring or whistling), plumonary emphysema (heaves, broken wind), bog spavin, side bone, navicular cisease, curb, with curby formation of hock, chorea (St. Vitas' dance, crampiness, shivering, string halt). In cases where stallions or jacks possess any of the above named unsoundnesses in a very aggravated or serious form the department 
of agriculture may upon investigation disqualify such stallion or jack from public service, if they consider him so unsound as to be unfit for breeding purposes.

SEC. 4. CERTIFICATES TO BE POSTED AND CONTAINED IN ADVERTISEIMENTS. Any owner or keeper of a registered stallion or jack over two years old offered for public service or for sale, exchange or transfer who represents or holds such animal as registered shall keep a copy of the state registration and certificate of soundness upon the door or stall of the stable where such animal is usually kept, and where such animals are advertised each and every advertisement shall contain a copy of such certificates or the substance thereof. Where certificates of registration have heretofore been issued by the state board of agriculture an additional certificate of registration shall not be required, but application for certificate of soundness shall be made as hereinbefore provided. Any owner or keeper of a stallion or jack over two years old otiner than registered offered for public service or for sale, exchange or transfer must secure certificates of soundness from the secretary of the state board of agriculture and advertise said stallion or jack by having and posting handbills or posters not less than five by seven inches in size, and said bills or posters musis have printed thereon, immediately preceding or above the name of the stallion the words "grade stallion" (or jack) in type not smaller than one inch in heighth, said bills or posters to be posted in a conspicuous manner at all places where the said stallion or jack is kept for public service, sale, exchange or transfer, together with a copy of the certificate of soundness issued by the secretaly of the state board of agriculture, and where such animals are advertised each and every advertisemen's shall contain a copy of said certificate or the substance thereof and the words "grade stallion" (or jack).

SEC. 5. EXAMINATION UPON COMPLAINT-EXPENSES, HOW PAID. When complaint is made to the state board of agriculture that a stallion or jack is diseased and on investigation it is by the department deemed necessary, an examination shall be made by the state veterinarian or his duly authorized deputy, the owner of such stallion or jack shall select some recognized graduate or licensed veterinarian to act with the state veterinarian and the said veterinarian shall, on receipt of a notice act jointly with the state veterinarian, and vinese two shall appoint a third graduate or licensed veterinarian to act with them and their decision shall be final. In case all three or any two of the experts declare the stallion or jack is eligible to receive or retain a licerse, then the expense of the con. sultation shall be paid by the state board of agriculture out of funds collected for registration fees, or if three or any two of the experis declare the stallion or jack not to be eligible in accordance with the provisions of this act, the expense incurred shall be paid by the person owning the animal and is may be collected in the same manner as in any case of appeal in civil action.

SEC. 6. TRANSFER OF UERTIFICATE-FEE. If the owner of any registered animal shall sell, exchange or transfer the same he shall file certificate, accompanying the same with a fee of fifty cents, with the secretary of the state board of agriculture, who shall, upon receipt of the required fee, issue a new certificate to the then new owner of the animal, and all fees provided by this act shall go into the treasury of the department of agriculture.

SEC. 7.-IMPORTED STALLIONS OR JACKS. Every person, firm, company $O I^{\circ}$ corporation importing from foreign countries any stallion or jack into the state of Iowa for use or public service, sale', exchange or transfer shall secure certificates of freedom from disease and unsoundness from a duly qualified or licensed veterinarian in this state, certifying that said animal is free from any or all 
diseases and unsoundnesses enumerated in section three (3). Said certificate must be filed with the secretary of the state board of agriculture, who shall issue a certified copy of said cervificate of soundness without charge to said importer, which shall serve as a temporary permit to offer said stallion for public service, sale, exchange or transfer until such time as original certificate of pedigree can be produced and stave certificate of enrollment and soundness issued. Said temporary permit shall be invalid after ninety (90) days from date of issue.

SEC. 8. CERTIFICATE OF SOUNDNESS. Add to chapter one hundred (100) of the acts of the 34th general assembly the following sections to follow section seven (7):

No sirallion or jack shall be brought into the state of Iowa from any other state unless accompanied by a certificate of soundness issued by a duly qualified veterinarian, who must be approved by the state veterinarian of the state in which the animal is purchased, such examination to cover all diseases and unsoundnesses specified in section three (3) of chapter one hundred (100) of the acts of the 34th general assembly as herein amended. Said certificate must be filed with the secretary of the suate board of agriculture, who shall issue a permit admitting said stallion or jack into the state.

SEC. 9. IMPORTATION PROHIBITED - UNLESS ACCOMPANIED BY VETERINARIAN'S CERTIFICATE-VIOLATION PUNISHED. On and after July 4, 1913, no railroad company transportaivon company or common carrier shall transport into the state of Iowa except for exhibition or racing purposes, any stallion or jack unless accompanied by a state veterinarian's certificate as provided in section four (4) of this act. Violation of this provision shall be punished as provided in section eight (8) of chapter one hundred $(100)$ of the acts of the 34 th general assembly.

SEC. 10. PERMANENT STATE CERTIFICATE OF SOUNDNESS-FEE. Any stallion or jack six years old or over and having successully passed veterinary examinations for soundness for two consecutive years shall be entitled to a permanent state certificate of soundness. The last examination must have been made within the year in which said certificate was granted provided, however, that said cerificate must be revurned each year to the secretary of the state Board of Agriculture with a fee of one dollar (\$1.00) for renewal and must be accompanied by a certificate signed by a duly qualified or licensed veterinarian that said animal is free from contagious, infectious or communicable diseases.

SEC. 11. BLIND STALLION OR JACK. The owner of any blind stallion or jack may upon application have the same examined at the expense of the owner of said animal by a board of three examiners, one to be the state veterinarian or his duly authorized deputy, one to ke selected by the owner of the animal who shall be a graduave or licensed veterinarian and these two shall appoint a third graduate or licensed veterinarian who shall act with them, and if upon examination and proof furnished, all three or any two members of said board declare that such blindness was caused by accident or disease not transmissable, then upon affidavit of said board the secretary of the State Board of Agriculture shall be authorized to issue a state certificate.

SEC. 12. IN EFFECT. This act being deemed of immediate importance shall take effect and be in force from and after its publication in the Register Leader and Des Moines Capital, newspapers published in the city of Des Moines, Iowa.

PUBLISHING FALSE PEDIGREES, ETC.-PENALTY.

Any person who shall fraudulently represent any animal, horse, catile, sheep or swine to be registered, or any person who shall post or publish or cause to be posted or published any false pedigree or 


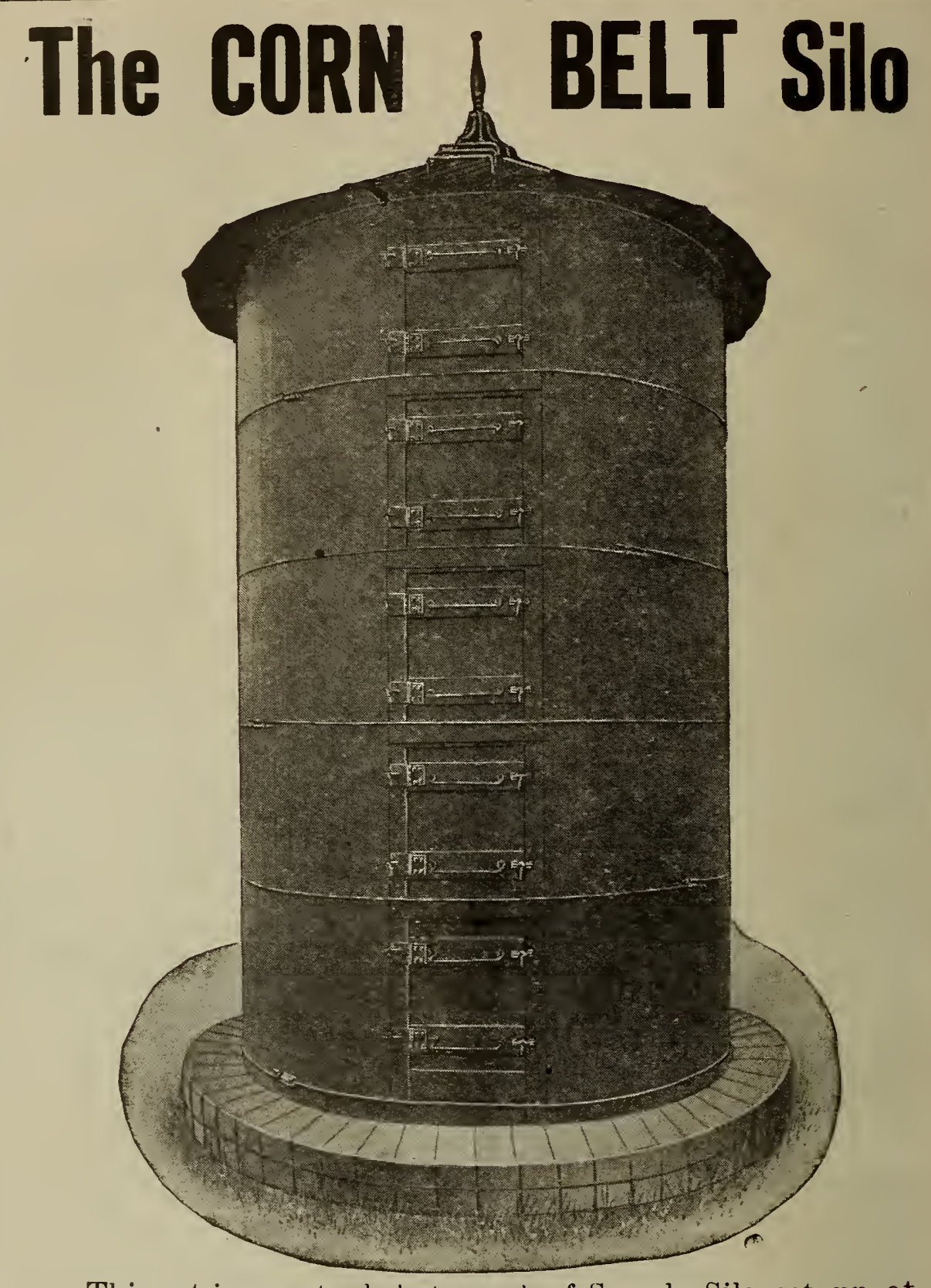

This cut is an actual photograph of Sample Silo set up at our office, 26th \& O Streets, South Omaha, Nebraska.

Call in and see same. We are sure that you will be pleased with it. We will take pleasure in showing same to you.

\section{Made for us by the PACIFIC TANK \& SILO CO.} Under Winner and Horder patents

When you buy a CorN BeLt Silo you get it CoMplete From Roof To GRound. You pay for many extras on other silos; the roof is extra on many-but our prices are for a complete silo, excepting the foundation. With every silo sold we furnish complete directions for erecting. Don't take an expert to erect it.

Louis Bradford Lumber Company Wholesale and Retail Lumber, Lath, Shingles, Etc. Office: 26th \& 0 Sts. So. Omaha, Neb. 


\section{Dairy Profits}

The experience of many farmers has shown that a silo pays for itself in one season, therefore yielding a return of 100 per cent right after the first season. The silo is today an absolute necessity to the sucessful farmer. The low cost of silage as compared with other feed is a great factor in modern farming. When you stop to think that the same acreage which formerly supported ten can support, with the addition of a silo, fifteen to twenty cows, it does not take long to figure out the protits to

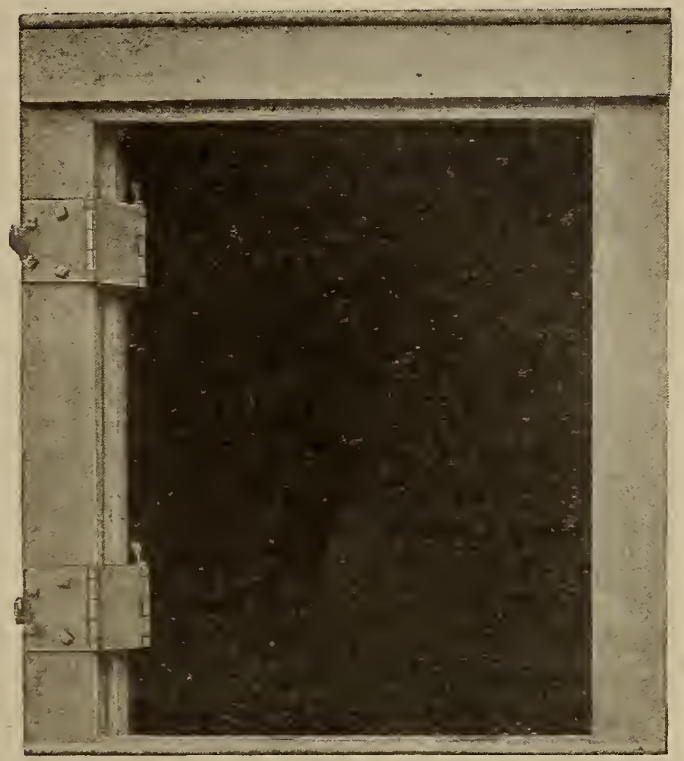
you. More milk with but little over the cost of feed is another result of feeding silage. With the present high price of land a good silo is as necessary today to the up-to-date farmer as a cream separator.

\section{Are You Silo Wise?}

Silo wisdom means

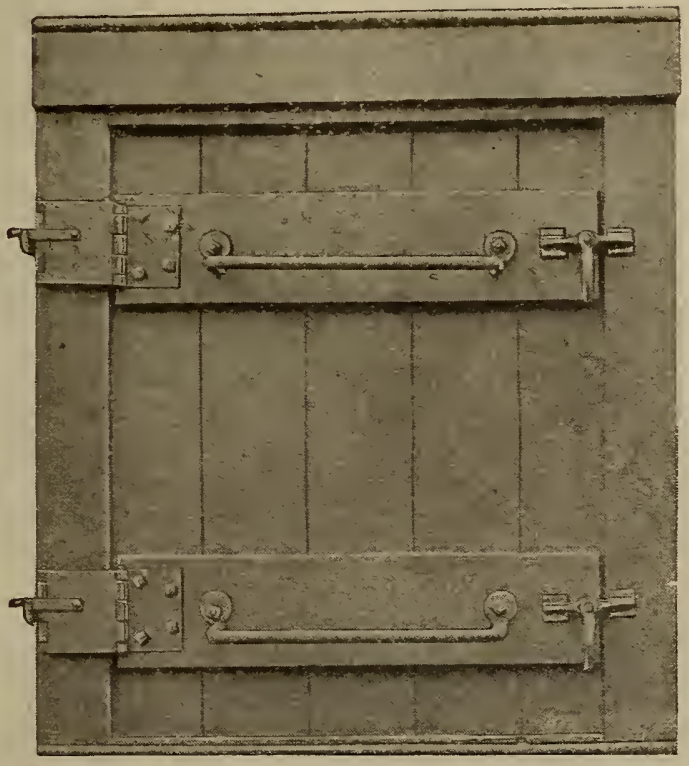
larger profits for you. Order a "CoRn BELT" Silo right now. If you want a "CorN BeLT" Silo in a couple of months, don't wait until then, but order it now. We will ship when instructed to do so. Remember that thousands of farmers will want "CoRN BelT" SIlos. Get your order in early.

Call and See Sample SILO.

WRITE FOR BOOKLET.

\section{Louis Bradford Lumber Company}

Wholesale and Retail Lumber, Lath, Shingles, Etc. Office: 26th \& 0 Sts. So. Omaha, Neb. 
certificate of soundness, or shall use any stallion or jack over two years old for public service or sell, exchange or transfer any stallion or jack over two years old, representing such animal to be registered, without first having such animal registered, and obtaining the certificate of soundness from the state board of agriculture, as hereinbefore provided, or who shall violate any of the provisions of this act, shall be guilty of a misdemeanor, and be punished by a fine of not more than one hundred dollars, or imprisoned in the county jail not exceeding thirty days, or both by fine and imprisonment.

WHEN EFFECTIVE-REPEAL-PENDING LITIGATION.

This act shall take effect and be in force from and after the first day of January.

\section{LIEN UPON PROGENY OF STALLION FOR SERVICE FEE.}

SECTION 1. The owner or keeper of a stallion kept for public services who has complied with sections twenty-three hundred and forty-one-a (2341a), twenty-three hundred and forty-one-b (2341-b) twenty-three hundred and forty-one-c (2341-c) and twen'sy-three hundred and forty-one-d (2341-d), of the supplement to the code, 1907 shall have' a prior lien upon the progeny of such stallion to secure the amount due owner or keeper for the service of such stallion, resuliving in said progeny, provided that where such owner or keeper misrepresents such stallion by false pedigree no lien shall be obtained.

SEC. 2. LIMITATION OF LIEN. The lien herein provided for shall remain in force for a period of six months from the birth of said progeny and shall not be enforced thereafter.

SEC. 3. ENFORCEMENT-PROCEDURE. The' owner or keeper of such stallion may enforce the lien herein provided by placing in the hands of any constable an affidavit containing a description of the stallion and a description of the dam and the time and terms of service, and said constable shall thereupon take possession of said progeny and sell the same for non-payment of service fee by giving the owner of said progeny ten (10) days written notice which notice notice shall contain a copy of the affidavit and a full description of the progeny to be sold, and time and hour when, and the place at which the sale will take place, and posting for the same length of time in three public places in the township of such owner's residence a copy of such notice. If payment of ine service fee and the costs are not made before the date thus fixed the constable may sell at public auction to the highest bidder such progeny and the owner or keeper of the stallion may be a bidder at such sale. The constable shall apply "she proceeds first in the payment of the costs, second, in the payment of the service fee. Any surplus arising from sale shall be returned to the owner of the progeny.

SEC. 4. THE RIGHT TO FORECLOSE MAY BE CONTESTED. The right of the owner or keeper to forclose, as well as the amount claimed to be due may be contested by anyone interested in so doing, and the proceding may be vransferred to the district court, for which purpose an injunction may issue, if necessary.

\section{Domestic Animals}

MEANING OF TERMS. As used in this chapter, the term "owner" used with reference to animals, means anyone entitle $\pi_{1}$ to the present possession thereof, the one having care or charge of them and the person holding the legal title to them, and as to land the person having title thereto, or the lessee or occupant thereof; the term "stock" means cattle, horses, mules and asses; the term "animals" means all animals which may be distrained under this chapter; and "trespassing stock or animals" means those 
unlawfully upon land, or running at large contrary to law or police regulations.

MALE ANIMALS RUNNING AT LARGE. The owner of any stallion, jack, bull, boar or buck shall restrain the same, and any person may take possession of any such animal running at large in the county in which such person resides or in which he occupies or uses real estate, and give notice thereof to any constable in the county where taken, who shall sell the animal so taken at public auction to the highest bidder for cash, having given ten days' notice of the time and place of sale describing the property, by posing the same in three public places in the township wherein such animal was found at large. Out of the proceeds of sale he shall pay all costs and any damage done by said animal, to be investigated and determined by him, and pay the remainder into the county treasury for the use of the county. If legal proof be made to the county auditor by the owner of said animal of his right thereto at any time within twelve months from the sale he shall order the proper amount to be paid to the owner out of any money in the treasury not otherwise appropriaised. If the owner, or any person for him, shall, on or before the day of sale pay the costs thus far made, and all damages to be determined by the constable if the parties cannot agree and make satisfactory proof of his ownership, the constable shall release the animal to him.

DISTRAINT DAMAGE FEASANT-RECOVERY.. Any animal trespassing upon land fenced as provided by law may be distrained by the owner of such land, and held for all damages done thereon by it unless it escaped from adjoining land in consequence of the neglect of such land owner to maintain his part of a lawful partition fence. The owner of the land from which such animal escaped shall also be liable for such damages if it escaped therefrom in consequence of his neglects to maintain his part of a lawful partition fence, or if the trespassing animal was not lawfully upon his land, and he had knowledge thereof. If there be no lawful partition fence, and the line thereof has not been assigned either by the fence viewers or by agreement of the parties any animal trespassing across such parvition line shall not be distrained, nor shall there be any liability therefor.

WHAT ANIMALS NOT PERMITTED TO RUN AT LARGE. Swine, sheep and goats at all times, and, during the time and as required by a police regulation adopted according to law, stock shall be restrained from running at large. Animals thus prohibited from running at large when trespassing on land, or a road adjoining thereso, may be distrained by the owner of such land, and held for damages done by them, and for the costs provided in this chapter; but stock shall not be considered as running at large so long as it is upon unimproved lands and under the immediate care and efficient control of the owner or upon the public roads for travel or driving thereon under like care and control. But where a partition fence is required by law to be erected or maintained, stock escaping across such partition line shall be dealt with as provided in the preceding section.

RECOVERY OF DAMAGES. Instead of distraining trespassing stock or animals, the injured person may recover all damages caused thereby in an action against the owner thereof, and may join therein the owner of the land from which it escaped if he is liable therefor. If distrained stock or animals escape or are released without the consent of the distraining party, he may recover his damages as above provided, with costs, and the costs of distraint made prior to such escape or release.

APPORTIONMENT OF DAMAGES. If there is more than one owner of distrained stock or animals, each may pay his rateable share of the damages and costs, and release his 
animals. If the injured party elects to sue therefor, he may join in one action all or any of such owners who have not paid their proportion of the damages and costs.

proportion of the damages aF DAMAGES-SALE. Within twentyfour hours after an animal has been distrained, Sunday not included the person disuraining, or his agent, shall notify the owner of the animal thereof, and, if he fails to satisfy the damages and costs, such person shall within twenty-four hours after such notice to the owner. verbally or in writing, request the vownship trustees to appear upon the premises to view and assess the damages. When two or more trustees have met, one of them having previously informed the owner of the animal of the fime and place of meeting, they shall assess the damages and costs. If the owner of the distrained animal refuses or neglects for two days thereafter to pay the amount thus assessed, one of said siustees shall put up in three conspicuous places in the township notices describing the property, and naming a time and place of sale, which place shall be where the property is distrained, and time not less than five nor more thàn ten days thereafter, that said property will be sol between the hours of one and three o'clock in the afternoon. At the time and place of sale, one of said trustees shall offer for sale and sell the property at public outcry to the highest bidder for cash, but no sale shall be made after having realized a sufficien's sum with which to pay the damages and costs, any remaining animals unsold to be at once returned to the owner, and also the surplus remaining if any, out of any sold. If for any reason a trustee cannot sit, the remaining trustees may appoint any disin'serested citizen having the qualifications of a juror to act in his place.

ASSESSMENT MADE-APPEAL. The trustees shall make their assessment in writing and file the same with the township clerk, which shall be recorded by him. Any person aggrieved by the action of the trustees may appeal is the district court of the county. The appeal bond conditioned to pay all costs and damages, shall be filed with and the sureties approved by the township clerk, in a penalty double the value of the property distrained, or if the value of the property exceeds the amount of the damages claimed, then double the amount of the damages and costs. Notice of such appeal shall be given within five days and in the same manner as in appeals from a judgment of a jusice of the peace. The appellant shall file an appeal bond within three days, Sunday not included, from the filing of the finding of the trustees, and when an appeal is thus taken by the claimant, the distrained stock or animals shall be held for the satisfaction of such judgment as may be rendered on appeal but the owner of said stock or animals may release the same at any time before judgment, by filing with the township clerk before the appeal is certified, or with the clerk of the district cours thereafter, a bond with sufficient sureties to be approved by the clerk with whom filed, conditioned to pay all damages and costs recovered in said cause on appeal. The clerk receiving such bond shall file the same, and forthwith certify the fact to the person having charge of the distrained stock or animals, who shall thereupon release the same to the owner. Where the owner appeals and files a bond, as herein provided it shall operate as a supersedeas, and the distrained stock or animals shall be released to him. Within five days after the taking of the appeal, the township clerk shall make out a certified transcript of the record of the finding of the trustees, and file the same together with the notice of appeal, if in writing, and the bond with the clerk of the district court.

ESCAPE OR RELEASE-RECAPTURE. If any distrained animal escape or is unlawfuliy released, the injured person may recapture the same, and nrnceedings under this chapter shall continue until the assessment of damages is made, which shall be con- 
.

When

You Ship

\section{Your Cattle, Hogs or Sheep}

The man behind the Sale should be your first and greatest consideration. If YOU want the best results, and for the RIGHT MAN behind YOUR Sale consign to us.

\section{Our Service Cannot Be Excelled}

100 or $200-1 \mathrm{bs}$. saved in shrink adds to your profits. and every extra nickel means $\$ 8.00$ or $\$ 10.00$. Think it over. We do not forget care when FILLING, neither should you forget care when BILLING. We want you to know our System. It stands for Experience, Energy, and Salesmanship. Give us YOUR NEXT SHIPMEN'T, IT WILL BE HANDLED WITH EXTREME CARE

For market reports, phone, wire or write us, and for proper results consign to us.

The Big 4 Live Stock Commission Co. 
We are Live Stock Commission Merchants and we solicit your consignments of live stock which you ship to the Sioux City Market.

\section{$=$ \\ We Cordially Invite You to Visit Us}

Make Our Office Your Headquarters When in Sioux City

FITZSIMMONS - PEIRCE

Live Stock Commission Company 
clusive unless appealed from. Notice of the sale of such animal shall be given by the trustees as soon as possession thereof is regained by the distrainor, and the property sold accordingly, unless he regains such possession before the day of sale as originally fixed, in which event the property shall be sold under the first notice.

PUNISHMENT FOR UNLAWFUL RELEASE. If anyone, without leave of the person having any animal under disiraint, release the same, he shall be guilty of a misdemeanor.

ESTRAYS. Any animal of an unknown owner running at large or trespassing within a lawful inclosure is an estray, and may be taken up by any householder in the county. except an unbroken animal between the first day of May and the first day of November, where such unbroken animal is not required to be restrained by a police regulation.

TAKING UP. If any animal, liable to be taken up as an estray comes upon any householder's premises, any person may notify him of the fact, and, if he fail to take up such estray for more than five days thereafter, any other householder in the same township may take it up and proceed with it as if Jaken upon his own premises if he shall produce proof to a justice of the peace of the service of such notice. All persons taking up stray animals shall state under oath before said justice where the same were taken up.

NOTICES POSTED. Any person taking up an estray shall within five days thereafter post up a written notice in three of the most public places in the township, which notice shall contain a full description of said animal and a statement as to where the same was taken up. Unless such estray shall have been previously claimed by the owner, the person taking it up shall within ten days go before a justice of the peace in the township in which the estray was taken up, or, in case there is no justice in the township, then before the next nearest justice in the county, and make oath to the correctness of said notice, together with a statement attached thereto as to whether the marks or brands of said animal have been altered to his knowledge either before or after the same was taken up, which notice shall be recorded by the justice in his estray book, and within five days forwarded by him to the county auditor, who shall enter the same in the estray book in his office, and shall cause a copy of said notice to be posted at the court house door.

PUBLICATION. If the estray is stock, the auditor shall cause the notice to be published once each week for three weeks in some newspaper in the county.

FEES AND EXPENSES. The person taking up an estray shall pay the fee of the justice for administering the oath. recording she notice in his estray book and forwarding the notice to the auditor, and shall also pay to the justice, to be transmitted to the auditor, the fee of the auditor for entering the notice in his estray book, and for posting a copy of the notice, and also, if the estray is stock, the sum of one dollar and fifty cents to cover the expense of publishing the notice, which amount so paid in advance for fees and expenses, together with the compensation allowed by law. shall be refunded to the person taking up such estray by the owner of it, in case restitution is made to him. If two or more estrays are taken up at the same time by the same person, they shall be included in one notice, and but one fee shall be paid therefor, and if unly a part of the stock thus included is restored to the owner, a proportionate amount of such fees and expenses shall be refunded.

PROPERTY VESTS. WHEN. If the estray be stock, and be not claimed by the owner within one year, or, being any other domestic animal, be not claimed by the owner within six months from the time it is taken up, the property therein shall vest in the taker up, if he las complied with the provisions of this chapter. 
RECOVERY BY OWNER. At at time before the property in the estray vest in the person who has taken it up, the owner shall be entitled to recover possession of it on paying to the person who has taken it up the compensation to which he is entitled by law, and the fees and expenses which he has paid out in advance, together with any reward which has been offered by the owner and a reasonable allowance for the expenses of keeping such estray, taking into account the use which she person taking up has had of it, which allowance shall be made by the justice of the peace before whom a proceeding to recover the animal shall be brought in the event the owner and the taker-up cannot agree with reference thereto.

VALUE RECOVERED. At any time within six months after the property in an estray has vested in the taker-up, the owner shall be entitled on demand to be paid by the said takerup the value of the estray not including any increased value which has accrued since it was taken up, after deducting therefrom the compensation, reward, fees and expenses referred to in the preceding section; or the taker-up may, at his option, elect to surrender the es tray, if still in his possession, in which case the owner must pay such compensation, reward fees and expenses.

USE OR APPROPRIATION. Any person legally taking up an esray may use or work it, if he does so with care and moderation and does not abuse or injure it. But if any person unlawfully take up any estray or take up any estray and fail to comply with any of the provisions of this chapter, or use or work it in any manner contrary to this chapter, or work is before having it appraised, or keep it out of the county for more than five days at any one time before he acquires a title to it he shall forfeit to the county twenty dollars, to be sued for by any person in the county; and the owner of the estray may also recover from such offender double the amount of the injury sustained, with costs. Estrays adapted thereto may be bred and milked by the taker-up.

FINDER NOT LIABLE. If any estray, legally taken up, escape from the finder or die without any fault on his part, he shall not be liable for the loss.

PENALTY AGAINST FINDER. If any person shall sell, trade or take out of the state any estray before the legal title shall have vested in him, he shall forfeit to the owner double its value, and shall also be guilty of a misdemeanor. But the auditor may authorize the taker-up to transfer the estray to another, who shall take the place of his predecessor.

PENALTY AGAINST OFFICER. If any printer, auditor or justice of the peace fail to perform the duties enjoined upon him in this chapter in relation to estrays, he shall forfeit to the counsy not less than five nor more than fifty dollars, to be sued for by any person in the county.

BOND TO RELEASE. Before any property held under this chapter. vests in the taker-up it may be released at once upon the owner giving to the holder a.bond to be approved by the justice of the peace before whom the proceedings concerning the property have been had conditioned to pay to the holder of the property, within twenty days after such approval, all costs and damage's to which he is entitled on account of his action and loss in the matter.

MARKS AND BRANDS. The board of supervisors of each county shall procure, at the expense of the county, a book for each civil township, to be in the custody of the township clerk, in which to record the marks and brands of horses, sheep, hogs and other animals.

RECORD. Any person wishing to mark or brand his domestic animals with any distinguishing mark may adopt his 
own mark, and have a description thereof recorded by the clerk of the township in which the owner lives, for which such clerk shall receive a fee of twenty-five cents.

MARK PREVIOUSLY RECORDED. No łperson shall adopt a mark or brand previously recorded to another person residing in the same township nor shall the clerk record the same one to two persons, unless on their joint application.

ABANDONED ANIMALS. Any person may take charge of any animal whose owner has abandoned it, or fails to properly take care and provide for it, and may furnish the same with proper shelter, nourishment and care at the owner's expense, and shall have a lien on such animal for the same, which, at the expiration of three months, shall become a perfect title to the property.

FOOD AND W'ATER SUPPLIED. In case any animal impounded or otherwise confined shall be without necessary food or water for more than iwelve successive hours it shall be lawful for any person, as often as necessary, to enter the pound, inclosure or building and supply it with necessary food and water so long as it shall remain so confined, and the reasonable cost of the same may be collected by him from the owner of the animal.

DISEASED ANIMALS KILLED. The sheriff, constable, police officer, officer of any society for the prevention of cruelty to animals, or any magistrate shall destroy any horse or other animal disabled and unfit for further use.

DOGS KILLED. It shall be lawful for any person to kill any dog caught in the act of worrying, maiming or killing any sheep or lamb or other domestic animal, or any dog atiacking or attempting to bite any person, and the owner shall be liable to the party injured for all damages done by his dog, except when the party is doing an unlawful act. The provisions of shis section shall not apply to any damage done by a dog affected with hydrophobia.

\section{Live Stock Running at Large}

RESTRAINING LIVE STOCK-SUBMISSION TO VOTERS. The board of supervisors may submit to the people of the county at any regular election, or at a special one called for thas purpose, and on the petition of one-fourth of the legal voters must submit, one of the following questions of police regulation:

1. Shall stock be restrained from running a's large?

2. Shall stock be restrained from running at large between sunset and sunrise?

3. Shall stock be restrained from running at large from the first day of (naming the month) in each year, until the first day of (naming the monin) following?

4. Shall stock be restrained from running at large between sunset and sunrise from the first day of (naming the month) in each year, until the first day of (naming the month) following?

The word "stock" as used in this section shall have the same. meaning as in the chapter of this code relating to domestic animals.

\section{Criminal-Amimals}

INJURIES TO BEASTS. If any person maliciously kill, maim or disfigure any horse, cattle or other domestic beast of another or maliciously administer poison to any such animal; or expose any poisonous substance with inten's that the same should be taken by such an animal, he shall be imprisoned in the penitentiary not exceeding five years, or imprisoned in the county jail not exceeding one year, or be fined not exceeding three hundred dollars. 
DRIVING AWAY STOCK. If any person knowingly or wilfully drive off or suffer or permit to be driven off, any stock of another to a distance exceeding one mile from the residence of the owner, or of his agent having charge of such stock, or the range in which such stock is usually in the habit of running. without the consent of such owner or agent, he shall be fined not exceeding one hundred dollars, or be imprisoned in the county jail not exceedceeding thirty days; and any justice of the peace in any county through which the stock thus driven off should pass, or in which it may be found, shall have jurisdiction of the offense.

DISTURBING STOCK. Any person who knowingly discharges firearms of any description within, or in the immediate vicinity of, any inclosure where cattle, hogs or sheep are being fed for the purpose of fatiening the same; or any person who enters such inclosure with firearms or dog unless such person shall be the owner of said stock, or have the control of the same, or shall have permission from such owner or the person having control thereof to enter said premises, shall be guilty of a misdemeanor.

TO FENCE, PRODUCE OR FIXTURES. If any person maliciously or mischievously break down, mar, deface or injure any fence, hedge or ditch inclosing lands belonging to another; or throw down or leave open any gate or bars not his own or under his charge, whereby an injury is done to another; or malicously injure destroy or sever from the land of another any produce thereof, or anything attached thereto, he shall be imprisoned in the county jail not more than one vear, or be fined not exceeding five hundred dollars or both.

CRUELTY TO ANIMALS. If any person torture, torment, deprive of necessary sustenance, mutilate, overdrive, cruelly bea's or cruelly kill any animal, or unnecessarily fail to provide the same with proper food, drink shelter or protection from the weather, or drive or work the same when unfit for labor or cruelly abandon the same, or carry or cause the same to be cruelly carried on any vehicle or otherwise, he shall be imprisoned in the county jail not exceeding thiridy days, or be fined not exceeding one hundred dollars.

BY RAILWIAYS WHEN TRANSPORTING. No railway company in this state in the carrying or transportation of cattle sheep, swine or other animals, shall confine the same in cars for a longer period than twenty-eight consecutive hours, unless delayed by storm or other accidental cause, without unloading for rest water and feeding for a period of at least five consecutive hours. In estimating such confinement the time the animals have been confined without such rest on connecting railways from which they are received shall be computed, it being the intention of this section to prevent their continuous confinement beyond twenty-eight hours, except upon the contingencies before stated; and animals unloaded for rest water and feeding shall be properly fed, watered and sheltered during such rest by the owners or persons in custody thereof, and said company shall have a lien upon such animals for food, care and custody furnished and shall not be liable for any detention of such animals authorized by this section. But when such animals shall be carried in cars in which they shall and do have proper food, water, space and opportunity for rest. the foregoing provisions in regard to their being unloaded shall not apply. Any railway company, owner or custodian of such animals, who shall fail to comply with the provisions of this section shall, for each and every such offense, be liable for and forfeit and pay a penalty of not less than one hundred nor more than five hundred dollars.

IMPOUNDING ANIMALS WITHOUT FOOD AND WATER If any person impound or confine, or cause to be impounded or confined, in any pound or other place, any creature, 
and fail to supply the same during such confinement with a sufficient quantity of food and water, he shall be guilty of a misdemeanor. BRINGING DISEASED SHEEP INTO THE STATE. If the owner of sheep or any person having the same in charge, knowingly import or drive into this state sheep having any contagious disease; or knowingly turn out or suffer any sheep having any contagious disease to run at large upon any common, road or uninclosed land; or sell or dispose of any sheep knowing the same to be so diseased: he shall be fined in any sum no's less than fifty nor more than one hundred dollars.

BRINGING IN DISEASED HORSES, MULES, ETC. If any pexson knowingly import or bring within the state any" horse, mule or ass affected by the diseases known as nasal gleet, glanders or button-farcy, or suffer the same to run at large upon any common, road or uninclosed land or use or tie the same in any public place, or off his own premises, or sell, trade or offer for sale or trade any such animal, knowing the same to be so diseased, he shall be fined not less than fifty nor more than five hundred dollars, or be imprisoned not to exceed one year in the county jail, or both.

ALLOWING DISEASED HORSES, MULES, ETC., TO RUN AT LARGE. If any horse, mule, or ass reasonably supposed to be diseased with nasal gleet, glanders or botton-farcy, be found running at large without any known owner, it shall be lawful for the finder thereof to take such animal so found, before some justice of the peace, who shall forthwith cause the same to be examed by some veterinary surgeon, or other person skilled in such diseases and if on examination, it is ascertained to be so diseased, is shall be lawful for such justice of the peace to order such diseased animal to be immediately destroyed and buried; and the necessary expense accruing under the provisions of this section shall be defrayed out of the county treasury.

SWINE DYING FROM DISEASE. The owner or person having charge of any swine any of.which dic or are killed on account of any disease, shall upon such fact coming to his knowledge, immediately burn the same.

NOT TO BE SOLD. No person shall buy, sell, or deal in or give away or offer to buy, sell or deal in, any swine that have died of any disease or have been killed on acocunt of any disease.

NOR CONVEYED ALONG HIGHWAY. No person shall convey upon or along any public highway or other public ground, or any private land except that owned or leased by him, any diseased swine or swine that have died of or have been killed on account of any disease. Upon the trial for the violations of the provisions of this section, the proof that any person has hauled or is hauling dead swine from a neighborhood in which swine have been dying or are at the time dying, from any disease, shall be presumptive evidence of his guilt.

ALLOWING DISEASED HOGS TO ESCAPE. It shall be unlawful for any person negligently or wilfully to allow his hogs or those under his control, infested with any disease, to escape his control or run at large.

PENALTY. Any person violating or failing to comply with any provision of the four preceding sections shall be fined not less than five nor more than one hundred dollars or be imprisoned in the county jail nos to exceed thirty days, or both.

BRINGING DISEASED CATTLE INTO STATE. Any person driving any cattle into the state, or any agent, servant or employee of any railroad or other corporation who shall carry, transport or ship any cattle into this state, or any railroad company or other corporation or person who shall carry, ship or deliver any cattle into this state or the owner, controller, lessee or agent or em- 
ploye of any stock yard, receiving into such stock yard, or in any other inclosure for the detention of cattle in transit or shipmen $\iota$ or reshipmen's or sale any cattle brought,or shipped in any manner into this state which at the time they were either driven, brought, shipped or transported into this state, were in such condition as to infect with or to communicate to other cattle pleuro-pneumonia or splenitic or Texas fever, shall be fined not less than three hundred and not more than one thousand dollars or be imprisoned in the county jail not exceeding six months, or both.

ACTION FOR DAMAGES. Any person who shall be injured or damaged by any acts prohibited in the preceding section, in addition to the therein provided may recover she actual damages sustained by him from the person, agent employe or corporation therein mentioned, and neither said criminal proceeding nor said civil action shall be a bar to a conviction or to a recovery in the obher.

RACING OR FAST DRIVING ON HIGHWAYS. Any person who shall be guilty of racing or driving upon. public highway in a manner likely to endanger the persons, or lives of others, shall be guiliy of a misdemeanor, and shall be fined not exceeding one hundred dollars or be imprisoned in the county jail not. exceeding thirty days.

\section{Diseased Stock and Quarantine Laws}

APPOINTMEN'T-QUALIFICATION. The state veterinary sugeon shall be appointed by the governor, subject to removal by him for cause, who shall hold office for three years. $\mathrm{He}$ shall be a graduate of some regularly established veterinary college, skilled in that science, and shall be by virtue of his office a mem. ber of the state board of health.

POWERS-REGULATIONS. He shall have supervision of all contagious and infectious diseases among domestic animals in, or being driven or transported through, the state and is empowered to establish quarantine against animals thus diseased, or that have been exposed to others thus diseased, whether within or withous the state, and, with the concurrence of the state board of health, may make such rules and regulations as he may regard necessary for the prevention and suppression and against the spread of said disease or diseases which rules and regulations the executive council concurring, shall be published and enforced, and in the performance of his duties he may call for the assistance of any peace officer.

PENALTY FOR INTERFERING WITH. Any person who wilfully hinders, obstructs or resists said veterinary surgeon his assistants or any peace officer acting under him or them, when engaged in the duties or exercising the powers herein conferred, or violates any quarantine established by him or them, shall be guilty of a misdemeanor.

REPORT. Said surgeon shall biennially make a full and detailed report of his doings since his last report to the governor including his compensation and expenses, which report shall not exceed one hundred and fifty pages of printed matter.

DUTIES-DEPUTIES. Whenever a majority of any board of supervisors or township trustees, or any city or town council, whether in session or not shall in writing notify the governor of the prevalence of, or probable danger from any of said diseases, he shall notify the veterinary surgeon, who shall at once repair to the place designated in said notice and take such action as the exigencies may demand and the governor may, in case of emergency, appoint a substifute or assistants with like qualifications, and with equal powers and compensation. 
DESTRUCTION OF STOCK-COMPENSATION-APPEAL. Whenever in the opinion of the state veterinary surgeon the public safety demands the destruction of any stock, the same may be destroyed upon the written order of such surgeon with the consent of the owner, or upon approval of the governor, and by virtue of such order such surgeon his deputy or assistant, or any peace officer, may destroy such diseased stock, and the owner thereof shall be entitled to receive its aciual value in its condition when cordemned to be ascertained and fixed by the state veterinary surgeon and the nearest justice of the peace, who, if unable to agree shall call upon the nearesis or other justice of the peace upon whom they agree as umpire, and their judgment shall be final when the value of the stock, if not diseased, would not exceed twenty-five dollars; but in all other cases either party shall have the right of appeal to the district court but such appeal shall not delay the destruction of the diseased animals. The veterinary surgeon shall at once file with the governor his writiten report thereof, who shall, if found correct indorse his finding thereon, whereupon the auditor of state shall issue his warrant therefore upon the treasurer of the state who shall pay the same out of any moneys at his disposal under the provisions of this act, but no compensation shall be allowed for stock destroyed while in transit through or across the state, and the word "stock" as herein used shall be held to mean cat'lle, horses mules and asses.

CO-OPERATION WITH UNITED STATES. The governor with the veterinary surgeon, may co-operate with the government of the United Staves for the objects of this chapter, and the governor may accept and receipt for any moneys receivable by the state under the provisions of any act of congress which may at any time be in force upon this subject, and pay the same into the state treasury to be used acconding to the act of congress and the provisions of this chapter as nearly as may be.

COMPENSATION OF ASSISTANTS. Any person, except the veterinary surgeon, called upon under the provisions of this chapter, shall be allowed and receive two dollars per day while actually employed.

COMPENSATION OF VETERINARY SURGEON. When engaged in the discharge of his duties the veterinary surgeon shall receive the sum of five dollars per day and his actual expenses, the claim therefor to be itemized verified, accompanied with written vouchers and filed with the siate auditor, who shall allow the same and draw his warrant upon the treasury therefor.

SHEEP INSPECTOR. The board of supervisors of any county, when notified in writing by five or more sheep owners of such county that sheep disease with scab, or any other malignant, contagious disease, exists in such coun'y. shall at any regular or special meeting appoint a suitable verson as county sheep inspector, who shall take the oath of office, whose duties shall be as hereinafter prescribed and whose term of office shall be two years and until his successor is appointed and qualified.

TREATMENT OF DISEASED SHEEP. It shall be the duty of the sheep inspector, upon the complaint of three or more sheep owners that any sheep within his jurisdiction have the scab or any other malignant, contagious disease, to immediately inspects and report in writing the result of his inspection to the county auditor, to be filed by him for reference by the board of supervisors or any party concerned. And if he deem it necessary. in order to prevent the spread of the disease to the sheep of the other owners, he shall command the owner or agent to dip or otherwise treat such diseased sheep, and shall inspect such diseased sheep every month thereafter until such disease shall be eradicated.

EXPENSES. It shall be the duty of the sheep inspector to dip or otherwise treat such diseased sheep, should the 
owner or agent refuse to do so, and all costs, expenses and charges, together with a per diem of three dollars per day shall be charged against the owner of such sheep and shall be a lien thereon, and may be recovered in an action.

COMPENSATION OF INSPECTOR. Such compensation for the inspector shall be three dollars per day, and shall be paid by the owner of the sheep, or his agent if the disease is found to exist. In case no disease is found to exist, the complainants shall pay such fee.

INSPEQTION OF SHEEP FROM OUTSIDE THE STATE. Upon the arrival of any flock of sheep within the state from a distance of more than twenty miles outside the boundaries of the staie the owner or agent shall notify the inspector of the county in which such sheep are being held, and he' shall inspect the flock at the expense of the owner or agent; and if the sheep are found sound shall furnish the owner or agent a certificate, which shall be a passport to any par's of the state; but sheep in transport on board of railroad cars or passing through the state on such cars, shall not come within the provisions of this section. Any violation of, or failure to comply with, the provisions of this and the four preceding secivions by the owner of any she'ep shall subject him to a forfeiture of not to exceed one hundred dollars which shall be a lien on such sheep, and shall be recovered in an action by the county.

COMPENSATION UNDER THIS CHAPTER. The compensation for services under this chapter shall be as follows:

1. For distraining stock, fifty cents for each head not exceeding two, and twenty-five cents for each additional head taken on one distraint;

2. For distraining each stallion, jack or bull, one dollar; for distraining each boar or buck fifty cents;

3. For distraining any other animals, twenty-five cents each, not exceeding four and ten cents for each addivional head;

4. For keeping male stock named in section twenty-three hundred and twelve of this chapter fifty cents a day, and all other stock twenty-five cen's a day, from the time the same is taken up;

5. For keeping any other animals, ten cents a day from the time the same is taken up;

6. For posting notices and selling male animals the same fees as are allowed constables for like services upon execution;

7. For taking up as an estray one head of stock, fifivy cents, and twenty-five cents for each additional head at one time;

8. For taking up any other kind of estray animals, fifteen cents each;

9. To the justice of the peace, for all services in each case of Jaking up estrays, fifty cents;

10. To the county auditor for all services in each case of estrays including posting and publishing notice, but not including the fee of the printer, fifty cents;

11. To the township trustees for posting notices, twenty-five cents, and services not otherwise provided for, the same fees as are allowed in assessing damages done by trespassing animals, with five cents mileage each way;

12. To the township clerk, ten cents per each hundred words entered of record, the same fees for a copy thereof, and in addition twenty-five cents for his certificate thereto; and fifty cents for filing and approving an appeal bond.

ERADICATION OF HOG CHOLERA.

REGULATIONS ACCEPTED. "The governor is hereby authorized to accept on behalf of the state, any rules and regulations prepared by the secretary of agricul'sure of the United States for the eradication of hog cholera or swine plague in one or more counties of this state, and he, together with the state veteri- 


\section{Sioux City}

\section{Live Stock}

Commission

Company

"Home Market for the

\section{Great Northwest"}

The best informed Live Stock Growers and Shippers have found that the MOST NET MONEY

is almost invariably secured by shipping their stock to this market.

Sioux Gity Stock Yards 


\section{Florida Investments Multiply Rapidly}

Government reports are responsible for the statement that for every acre under cultivation in FLORIDA we can make three times as much per acre as any other place in the United States.

Have you made provision for an income when your earning power ceases? Every man strives to provide for a competency. An investment in FLORIDA CITRUS LANDS is one of the surest producers for old age on the market today.

In 1902 George E. Knplin of Winter Haven, Florida, purchased 7 1-2 acres of Citrus Lands in the Haines City district. His returns in 1906 were $\$ 250$ an acre net, and in 1912 his income from this tract was $\$ 11,902.31$; a net income cf over $\$ 1,000$ an acre. We believe he has made a good investment. What do you think?

\section{No Grop Failures in 50 Years}

We are offering land in this section where six lbrothers of us have been interested 12 years, on liberal terms, and will protect you by a guarantee which, in the event of your death before you have paid for your land, will cancel the indebtedness and present your family with a deed to the property. Join us on one of our car excursions 1st or 3rd Tuesday every month.

Send for our literature in detail and names of people that have invested.

\section{Florida Lake Region}

\section{Land Company}

408 First National Bank Bldg., Omaha, Nebr. 
nary surgeon may co-operate with the government of the: Unifare States for the objects of this act.

FEDERAL INSPECTORS. The inspectors of the burrean of animal industry of the United States department of: culture shall have the right of inspection, quarantine and corrdennation of animals affected with hog cholera or swine plague ox saspecised to be so affetced or that have been exposed to this diseasse. and for these purposes are hereby authorized and empowered to enter upon any ground or premises. It is hereby made the divty sheriffs, constables and peace officers to assist such inspectors. wireme so requested; and said inspectors shall have the same poxwars and protection as peace officers while engaged in the discharge of theiv duties.

DISEASED ANIMALS DESTROYED-COMPENSATUON.

Whenever any swine in the district specified ir twe regulations are found to be affected with or to have been exposer to hog cholera or swine plague, said swine may be condemned and $\mathrm{d}$ (astroyed; and the owners of all swine destroyed under the provisions: of this act shall be entitled to receive a reasonable compensation therefor but not more than the actual value in the condivion when condemned. In case of failure on the part of the inspector and the: owner to agree as to the amount of compensation, the swine shall be: appraised by a board of citizens of this state, one of whom maj be appointed by the inspector, one by the owner of the swine, and the two thus appointed shall select a third, and these together shall pro. ceed to appraise the amount to be paid to the owner for the animalss destroyed. Such appraisal shall be made under oath and shall bo final when the value of the animals does not exceed one hundred dollars, but in all other cases either party shall have the right of appeal to the district court but such appeal shall not delay the destruction of the diseased or exposed animals.

EXPENSES. All expenses of quarantine, condemnation: and destruction of swine under the provisions of this act, aras the expenses of any and all measures that may be used to eradieate: hog cholera shall be paid by the United States, and in no case shall this state be liable for any damages or expenses of any kind' unders the provisions of this act.

PENALTY. Any person violating any order of quarantine made under this act, or any regulations prescribed by the secretary of agriculture and accepted by the governor of this states for the eradication of hog cholera, shall be guilty of a misdemeanor, and upon conviction shall be punished by a fine of not less thare twenty-five dollars nor more than one hundred dollars.

\section{HOG CHOLERA SERUM.}

SECTION 1. HOG CHOLERA SERUM-LABORATOEYSUPERVISION-DIRECTOR AND ASSISTANTS-HOW AP. POIN'TED. The state board of education is hereby authorized and directed to establish at Ames, Iowa in connection with the Iowas state college of agriculture and mechanic arts, a laboratory for the: manufacture of hog cholera serum toxines, vaccines and biological products and to provide the necessary equipment therefor. The president of said college shall appoint the director of said laborators. and such assistants as are deemed necessary to efficiently carry on: said work and shall, with the approval of said board fix the alartes. of said assistants.

SEC. 2. SERUM-HOW SOLD. The director of said laboratory shall on application, furnish said serum to any person within the state of Iowa for use in his herd only, together with speciffe. instructions for the use of same, at the approximate cost of mancfacture, and such cost shall be stated on the package. Any surplas. serum or other biological products may be sold by said direcior at 
reasonable profit to any applicant outside of the state. The director of the serum laboratory is authorized to purchase serum or other bio.logical products which he deems reliable and he may sell the same at approximate cost in the same manner as products of the labora. tory are sold at any time it appears to him that the available sup. ply will not be sufficien's to meet the demand.

SEC. 3. MONEYS RECEIVED-WHERE DEPOSITEDVOUCHERS ISSUED-EXPENSES. The director shall issue re. ceipts for all moneys received by him for serum and other biological products sold and shall deposit all such funds with the treasurer of the college, which treasurer shall be responsible on his bond for the same. Upon receipt of said moneys the said treasurer shall issue duplicate receipts therefor, one of which he shall deliver to the director and the other to the secretary of the state board of educa.. tion. Said moneys shall be kept by said treasurer in the separate fund to be known as the serum fund, and he shall pay out from said fund as other college funds are expended, but only for expenses directly connected with the maintaining of said laboratory and the manufacture, purchase and distribution of said serum and biological products.

SEC. 4. DIRECTOR TO DECLARE STANDARD OF POTENCY-PERIMITS TO SELI-HOW ISSUED-FEES. The director of said laboratory shall have the power and it is made his duty to establish and declare the standard degree of potency of hog cholera serum for successfully treating, curbing and controlling hog cholera or swine plague. Any person, firm, company or corporation, before selling or offering for sale within this state any hog cholera serum, shall first make application to the director of the laboratory herein created, for permission to sell the same in the state. Said application shall give the name of said person, firm, company or corporation with its place or places of business. Such other information and samples of serum shall be furnished whenever required by the director. If the director is satisfied that said person firm, company or coporation is fit, proper and reliable, upon the furnishing of a bond in the sum of one thousand dollars $(\$ 1000.00)$ by said applicant, which bond shall be approved by the director, he shall issue to said person, firm, company or corporation a permis to sell said serum within the state for a period of one calendar year or part thereof, for which permit he shall collect the sum of twenty-five dollars: $(\$ 25.00)$, which money shall be deposited and handled the same as moneys received for the sale of serum. At the time of issuing said permit the said director shall deliver to said applicant a statement showing the standard or degree of potency of hog cholera serum as established by said director and said permit may at any time be revoked and cancelled by said director when it becomes evident to him that the terms on which it was issued are being violated. No hog cholera serum shall be sold or offered or kept for sale or use, or be used in this state which is below the standard test of potency established by the director, except for experimental purposes at the place of manufacture of hog cholera serum and under the direction of the manager thereof.

SEC. 5. INSPECTION-FORFEITURE. The bond required in section four (4) of this act, shall be to the effect that the person, firm, company or corporation holding a permit shall forfeit and pay to the director the sum of five hundred dollars $(\$ 500.00)$ whenever upon inspection it shall be ascertained that any serum kept for sale or distribution or offered for sale by any person, firm, company or corporation is below the standard provided for by the director. which money shall, when collected, be deposited and handled the same as moneys received from the sale of serum. The attorney general is hereby authorized and it is his duty to proceed upon the bond ito collect the amount forfeited. 
SEC. 6. VIRUS-HOW SOLD-BY WHOM-VIOLATIONPUNISHMENT. The director of said laboratory is authorized to procure virulent blood or virus from cholera infected hogs and to distribute the same at approximate cost for use with hog cholera serum and under restrictions concerning payments as established in section three (3) of this act. No person firm, company or corporation shall distribute or sell any portion of virulent blood or virus from cholera infected hogs unless permitted in wriving so to do by the director of said laboratory and under such regulations as the said director may issue, and such permit shall specify the time and place, and when and where the said virus may be used. And no person shall use any portion of virulent blood or virus from cholera infected hogs unless he has received special instruction in reference to such use of such virulent blood or virus which is satisfactory to the director of said laboratory and said director has issued a permit to such person, and such permit shall be cancelled by said director for cause which said director may deem sufficient; provided that these restrictions shall not apply to official work of, first, veterinary members of the animal health commission or, second, representatives of the United States bureau of animal industry; but all virulent blood or virus used by such persons shall be reported to the directior of the serum laboratory in such manner as he may require. Any person, firm, company or corporation violating the terms herein stated shall be punished the same as provided for in section eight (8) of this act.

SEC. 7. SEIZURE-EXAMINATION. The director of saic? laboratory or the sute veterinarian or their duly qualified deputies or assistants are hereby authorized to seize and forward to the state laboratory for examination, samples of any serum or virus used or kept for use or for sale within this state, at any time or any place, under the police and health regulations in force in this state. The director of the state laboratory shall have power to condemn or destroy any serum or virus which he deems to be unsafe.

SEC. 8. VIOLATION-PENALTY. After the taking efiect of this act any person, firm company or corporation offering or keeping: for sale in this state any hog cholera serum or virus without securing a permit from the director, or selling or offering or keeping for sale after said permit has heen cancelled or has expired any hog cholera. serum, or while holding a permit, selling or offering or keeping for sale any hog cholera serum which is below the standard of potency, as established and declared by said director, shall be fined in a sum not less than one hundred dollars $(\$ 100.00)$ or more than five hundred. dollars $(\$ 500.00)$. In default of the payment of such fine, the individual, or if it be a firm, company or a corporation offending, the managing agent or executive officer of such firm, company or corporation within the state, shall be imprisoned in the county jail not. less than thirty (30) days or more than one hundred and fifty (150). days.

SEC. 9. USE LIMITED TO CERTAIN SERUM. After the taking effect of this act, any person, firm, company or corporation wilfully using or keeping for use in this state any hog cholera serum other than wat manufactured at the state laboratory or that sold by a holder of a valid permit issued by the director of the laboratory shall: be punished as provided for in section eight (8) of this act.

SEC. 10. PRESENT LABORATORY DISCONTINUED.

The laboratory for the manufacture of hog cholera serum now being operated by the stave of Iowa, shall be discontinued and the state veterinarian is hereby directed to turn over to the director of the laboratory hereby provided for, the equipment of said discontinued laboratory. The state veterinarian is hereby authorized and directed to adjust all claims and leases and to dispose of the same in such manner and on such terms as shall be approved by the governor of the state of Iowa. 
SEC. 11. APPROPRIATION. There is hereby appropriated sout of any money in the state treasury nots otherwise appropriated the sum of thirty-five thousand dollars $(\$ 35000.00)$ or as much thereof as :may be necessary to carry out the provisions of this act. The above amount or so much thereof as may be necessary to carry out the provisions of said act shall be paid by warrants drawn by the auditor of state upon the state treasurer upon the order of the board of education.

\section{Liens}

LIENS OF LIVERY STABLE KEEPERS ETC. Livery and feed stable keepers, herders, feeders and keepers of stock for hire shall have a lien on all stock and property coming into their hands, as such for their charges and the expense of keeping, when received from the owner or any other person, subject to all prior liens of record. Any claimant of the property may release the lien by tendering the party in possession a bond, in a penal sum of three times : the amount for which the lien is claimed, signed by two sureties, residents of the county who shall justify as is required in other cases, and conditioned to pay any judgment the lien-holder may obtain for such charges. If such charges and expenses are not sooner paid, the Iien-holder may sell said property at public auction, after giving So the owner or claimant ten days' notice in writing of the time and place of such sale, if found within the county, and also by posting written notices thereof in three public places in the township where said stock was kept or let. And out of the proceeds of such sale he shall pay all of said charges and expenses of keeping said stock, together with the costs and expenses of said sale and the balance, if any shall be paid to the owner or claimant of said property.

\section{Fences}

PARTITION FENCES. The respective owners of adJoining tracts of land, except timber land not used otherwise than for the timber thereon, from which each derives any revenue or benefit, shall be compelled to erect and maintain partition fences, or contribute thereto, and keep the same in good repair throughout the year, and fif said fence be hedge, the owner theref shall trim or cut it back once in two years to within five feet from the ground, unless such owners otherwise agree in writing to be filed with and recorded by the townchip clerik.

POWERS OF FENCE VIEWERS. The fence viewers Ghall have power to determine any controversy arising under this chapter, upon giving five days notice in writing to the opposite party or parties, prescribing the time and place of meeting to hear and determinte the matter named in said notice. Upon the request of any Iand owner, the fence viewers shall give such notice to all adjoining land owners liable for their erection, maintainance, rebuiiding, trimming or cutting back, or repairing of a partition fence, or to pay for an existing hedge or fence. At said time and place the fence viewers shall meet and determine by written order the obligations, rights and duties of the respective parties in such matter, and assign to each owner the part which he shall erect, maintain, rebuild, trim or cut back, or pay for, and fix the value thereof, and prescribe the time within which the same shall be completed or paid Tor, and, in case of repair, may specify the kind of repairs to be made. ASSIGNMENTS OF PORTIONS. In case a land owner desires to erect a partition hedge or fence when the owner of the adjoining land is not liable to contribute thereto, the fence viewers may assign to each owner the part which he shall erect, maintain, rebuild and repair, trim or cut back, by pursuing the method provided in the oreceding section; but the adjoining owner shall not be required to 
contribute thereto until he becomes liable so to do, as elsewhere in this chapter provided.

DEFAULT-DAMAGES-HOW COLLECTED. If the erecting, rebuilding or repairing of such fence be not completed within thirty days from and after the time fixed therefor in such order, the adjoining owner may do or complete the same, and the value thereof may be fixed by the fence viewers, and unless the sum so fixed, together with all fees of the fence viewers caused by such default, as taxed by them, is paid to the land owner so erecting, rebuilding, trimming or cutting back or repairing such fence, within ten days after the same is so ascertained; or when ordered to pay for an existing fence, and the value therof is fixed by the fence viewers, and said sum together with the fees of the fence viewers as taxed by them, remains unpaid ; by the party in default for ten days, the fence viewers shall certify to the county auditor the full amount due from the party or parties in default, including all fees and cost taxed, together with a description of the real estated owner by the party or parties in defalt along or upon which the said fence exists, and the county auditor shall enter the same upon the tax list and the amount shall be collected as other taxes and when so collected same shall be paid to the party or other parties entitled thereto.

SERVICE OF NOTICE. The notices by the fence viewers provided for in this chapter may be served upon any owner non-resident of the county where his land is situated by publication thereof for two consecutive weeks in a newspaper printed in the county in which the land is situated, proof of which shall be made as in case of an original notice and filed with the fence viewers, and a copy delivered to the occupant of said land, or to any agent of the owner in charge of the same

ORDERS-NOTICE. All orders and decisions made by the fence viewers shall be in writing signed by at least two of them, and filed with the township clerk. All notices in this chapter required to be given shall be in writing, and return of service thereof made in the same manner as notices in actions before a justice of the peace. Such orders, decisions notices and returns shall be entered of record at length by the township clerk, and said record, or a copy thereof certified to be such by such township clerk, shall be competent evidence in all courts.

DIVISION RECORDED. The several owners may, in writing, agree upon the portion of partition fences between their lands which shall be erected and maintained by each, which writing shall describe the lands and the parts of the fences so assigned, be signed and acknowledged by them, and filed and recorded in the office of the recorder of deeds of the county or counties in which they are situated.

HOW FAR BINDING. Any order made by the fence viewers, or any agreement in writing between adjoining land owners, when recorded as in this chapter provided shall bind the makers, their heirs and subsequent grantees, except if the land of either shall cease to be used as a means for revenue or benefit, the same shall be inoperative while not thus used.

LANDS IN DIFFERENT TOWNSHIPS. When the adjoining lands are situated in different townships in the same or different counties the clerk of the township of the owner making the application shall select two trustees of his township as fence viewers, and the clerk of the other township one from his own township, who shall possess, in such case, all the powers given to fence viewers in this chapter but all orders, notices and valuations and taxation of costs made by them must be recorded in both townships.

FENCE ON ANOTHER'S LAND. When a person has made a fence or other improvement on an inclosure, which is found to be on land of another, such person may enter upon the 
land of the other and remove his fence or other improvement and material, upon his first paying or offering to pay, the other party for any damage to the soil which may be occasioned thereby, and the value of any timber used in said.improvement taken from the land of such other party, if any; and if the parties cannot agree as to the damages the fence viewers may determine them as in other cases; such removal shall be made as soon as practicable, but not so as to expose the crops of the other party.

LINE FENCES. A person building a fence may lay the same upon the line between him and the adjacent owners, so that it may be partly on one side and partly on the other, and the owner shall have the same right to remove it as if it were wholly on his own land.

FENCE ON ONE SIDE OF LINE. The provisions concerning partition fences shall apply to a fence standing wholly upon one side of the division line.

LAWFUL FENCE DEFINED. A lawful fence shall consist of three rails of good substantial material, or three boards not less than six (6) inches wide and three-quarters (3/4) of an inch thick, such rails or boards to be fastened in or to good substantial posts not more than ten (10) feet apart where rails are used, and not more than eight (8) feet apart where boards are used, or wire either wholly or in part substantially built and kept in good repair; or any other kind of fence, which in the opinion of the fence viewers, shall be equivalent thereto, the lowest or bottom rail, wire or board not more than twenty (20) nor less than sixteen (16) inches from the ground, the top rail, wire or board, to be between fortyeight (48) and fifty-four (54) inches in height, and the center rail, wire or board not less than twelve (12) nor more than eighteen (18) inches above the bottom rail, wire or board; or it shall consist of three (3) wires barbed with not less than thirty-six (36) iron barbs of two (2) points each or twenty-six (26) iron barbs of foul: (4) points each, on each rod of wire, or of four (4) wires, two (2) thus barbed and two (2) smooth the wires to be firmly fastened to posts not more than two (2) rods apart, with not less than two (2) stays between posts, or with posts not more than one (1) rod apart, without such stays the top wire to be not more than fifty-four (54) nor less than forty-eight (48) inches in height. Provided, however, that all partition fences may be made tight by the party desiring it, and when his portion is so completed, and securely fastened to good substantial posts, set firmly in the ground, not more than twenty (20) feet apart, the adjoining property owner shall construct his portion of the adjoining fence in a like tight manner, same to be securely fastened to good substantial posts, set firmly in the ground not more than twenty. (20) feet apart. All tight partition fences shall consist of not less than twenty-four (24) inches of substantial woven wire on the bottom, with three (3) strands of barb wire with not less than thirty-six (36) barbs of two points to the rod on top. the top wire to be not less than forty-eight (48) inches not more than fifty-four (54) inches high, or not less than eighteer (18) inch, substantial oven wire on the bottom with four (4) strands of barb wire or not less than thirty-six (36) barbs of two (2) points to the rod, the top wire to be not less than forty-eight (48) inches nor more than fifty-four (54) inches high or good substantial woven wire not less than forty-eight (48) inches nor more than fifty-four (54) inches high. In case adjoining owners or occupants of land shall use the same for pasturing sheep or swine, each shall keep his share of the partition fence in such condition as shall restrain such sheep or swine. Upon the application of either owner after notice given as prescribed in this chapter, the fence viewers shall determine all controversies arising under this section, including the partition fences made sheep and swine tight. 
WHERE STOCK RESTRAINED. This chapter shall be construed the same in counties where stock is restrained from running at large as where not so restrained.

APPEAL. An appeal may be taken to the district court from any order or decision of the fence viewers by any person affected in the same manner appeals are taken from justices of the peace, except that the appeal bond shall be approved by the township clerk, in which event the township clerk after recording the original papers shall file them in the office of the clerk of the district court, certifying them to be such, and the clerk shall docket them, entitling the applicant or petitioner as plaintiff, and it shall stand for trial as other cases.

RECORD KEPT-FEES OF CLERK. The township clerk shall enter all matters herein required to be made of record in his record book, and shall receive ten cents for each one hundred words in entering of record and making certified copies of the matters herein provided for, and twenty-five cents additional for his certificate thereto when required.

FENCES-CROPS. A reasonable time must be allowed to enable the owners of land to erect the necessary fences adjoining the (a) new road; and when crops have been so planted or sowed before the road is finally established the opening thereof shall be delayed until the crop is harvested.

CA'TTLE WAYS ACROSS HIGHWIAYS. Upon application to the board of supervisors of any county by any person for permission to construct a cattle-way across, over or under any public road, it may grant the same upon condition that such way shall not interfere with the public travel; that the grade of the road over the cattle-way shall not exceed one foot in ten feet; and that it shall not obstruct the watering at any running stream. The applicant shall construct the same at his own expense, and be responsible for all damages that may arise from its construction, or from the same not being kept in repair.

REPAIRS. If the person on whose land such cattleway is constructed fails to keep the same in repair, it shall be the duty of the road supervisor to make all necessary repairs, and charge the same to the owner of the land upon which such way is constructed, and upon his refusal or failure to pay, the supervisor shall recover the same in an action brought in his own name which money, when collected, shall be expended in improving or repairing the public roads in the district where such cattle-way is constructed.

APPLICATION FOR. Any perșon desiring to build a cattle-way across a public highway under any township bridge. may apply to the board of trustees of the township wherein the same is to be located, at any meeting thereof, and it may grant such application and prescribe such conditions in regard to the maintenance of said bridge as it may think proper.

PRIVATE CROSSINGS. When any person owns land on both sides of any railway, the corporation owning the same shall, when requested so to do make and keep in good repair one cattle-guard, and one causeway or other adequate means of crossing the same at such reasonable place as may be designated by the owner.

CATTLE-GUARDS-CROSSINGS-SIGNS. Every corporation constructing or operating a railway shall make proper cattle-guards where the same enters or leaves any improved or fenced land, and construct at all points where such railway crosses any public road good, sufficient and safe crossings and cattle-guards, and erect at such points, at a sufficient elevation from such road as to admit of free passage of vehicles of every kind a sign with large and distinct letters placed thereon, to give notice of the proximity of the railway, and warn persons of the necessity of looking out for trains. Any railway company neglecting or refusing to comply with the provisions 
of this section shall be liable for all damages sustained by reason of such refusal or neglect and it shall only be necessary in order to. recover, for the injured party to prove such neglect or refusal.

FAILURE TO FENCE-LIABILITY FOR STOCK KILLED-SPEED AI DEPOTS. Any corporation operating a railway, and failing to fence same against live stock running at large and maintain proper and sufficient cattle-guards at all points where the right to fence or maintain cattle-guards exists shall be liable to the ower of any stock killed or injured by reason of the want of such fence or cattle-guards for the full amount of the damages sustained by the owner on account thereof, unless it was occasioned by his wilful act or that of his agent; and to recover the same it shall only be necessary for him to prove the loss of or injury to. his property. If such corporation fails or neglects to pay such damages within thirty days after notice in writing that a loss or injury has occurred, accompanied by an affidavit thereof. served upon any officer or station or ticket agent employed by said corporation in the county where such loss or injury occurred, such owner shall be entitled to recover from the corporation double the amount of damages actually sustained by him. No law of the state or any local or police regulations of any county township, city or town, relating to the restraint of domestic animals, or in relation to the fences of farmers or land owners, shall be applicable to railway tracks unless specifically so stated in such law and regulation. Upon depot grounds necessarily used by the public and the corporation, the operating of trains at a greater rate of speed than eight miles an hour where no fence is built shall be negligence, and shall render such corporation liable for all damages occasioned thereby, in the same manner and to the same extent, except as to double damages, as in cases where the right to fence exists.

FENCES REQUIRED. All railway corporations owning or operating a line of railway within the state shall construct, maintain and keep in repair a suitable fence of posts and barb wire or posts and boards or any other fence which the fence viewers shall determine to be equivalent thereto, on each side of the track thereof, so connected with cattle-guards at all public road crossings as to prevent cattle horses and other live stock from getting on the railroad tracks. Such tracks shall be fenced within six months after the completion of the same or any part thereof. Such fences, when of barb wire, shall be of five wires to be not less than fifty-four inches high; or of five boards securely nailed to posts set not more than eight feet apart the fence to be not less than fifty-four inches high. Fences repaired or rebuilt shall conform to the foregoing provisions. Nothing in this or the two following sections shall be construed to compel a railway company operating a third-class line to fence its road through the land of any farmer or other person who, by written agreement with such company, waives the fencing thereof.

PENALTY-KILLING OF STOCK. If the corporation, officer thereof or lessees owning or engaged in the operation of any railroad in the state refuses or neglects to comply with any provision of this chapter relating to the fencing of the tracks, such corporation, officer or lessee shall be guilty of a misdemeanor, and upon conviction fined in a sum not exceeding five hundred dollars for each offense, and every thirty days' continuance of such refusal or neglect shall constitute a separate and distinct offense; but nothing herein contained shall be construed to relieve the corporation from liability arising from the killing or maiming of live stock on said track or right of way by its negligence or that of its employes nor shall anything in this chapter interfere with the right of open or private crossings, or with the right of persons to such crossings, 


\section{When in So. Omaha stop at the}

\section{GREER HOTEL}

(American Plan)

G. F. Gardner, Proprietor

\section{Special Rates to Stockmen}

\section{Rates per Day $\$ 1.25$}

515 North 25th St. South Omaha, Neb.

Hotel Keystone

1312 Douglas St., Omaha, Neb.

Hot and cold running water; steam heat, electric lights in all rooms.

RATES-With free bath, $50 \mathrm{c}$, $75 \mathrm{c}$., $\$ 1.00$-With private bath $\$ 1.50$.

Special rates by week or month.

H. Schoenwald and H. Schwartz, Proprietors
Charming New Wall Papers at Wholesale

\section{Prices}

and we pay freight charge: Our FREE Catalogue is. fu:! of the newest designs in wall papers-and contains a hosi of colored illustrations shorsing All the Latest Styles in interior decorating.

Write, wire or telephone. By all means get this elegun: catalogue it will show you how to paper your home in a n:evu way-make it entirely diffe? ent from your neighbor's.

Gate City Wall Paper Go.

Art Kraft Wall Papers and Window Shades 2233 Farnam Street. ONAHA, NEBRASKA, O. S. A. 


\section{It's Your Turn Next}

To become the possessor of one of our durable hand-made concord harness at this special price.

We will ship you this harness, or any harness you order, and if you do not find it as represented in every particular, you can send it back at our expense.

Send a postal for a catalog of our many designs of harness and horse furnishings. It includes everything in the harness line you will require and at prices that will please you.

Write today. Ouir mail order department will give you prompt attention.

\section{One Sample of Our Offerings}

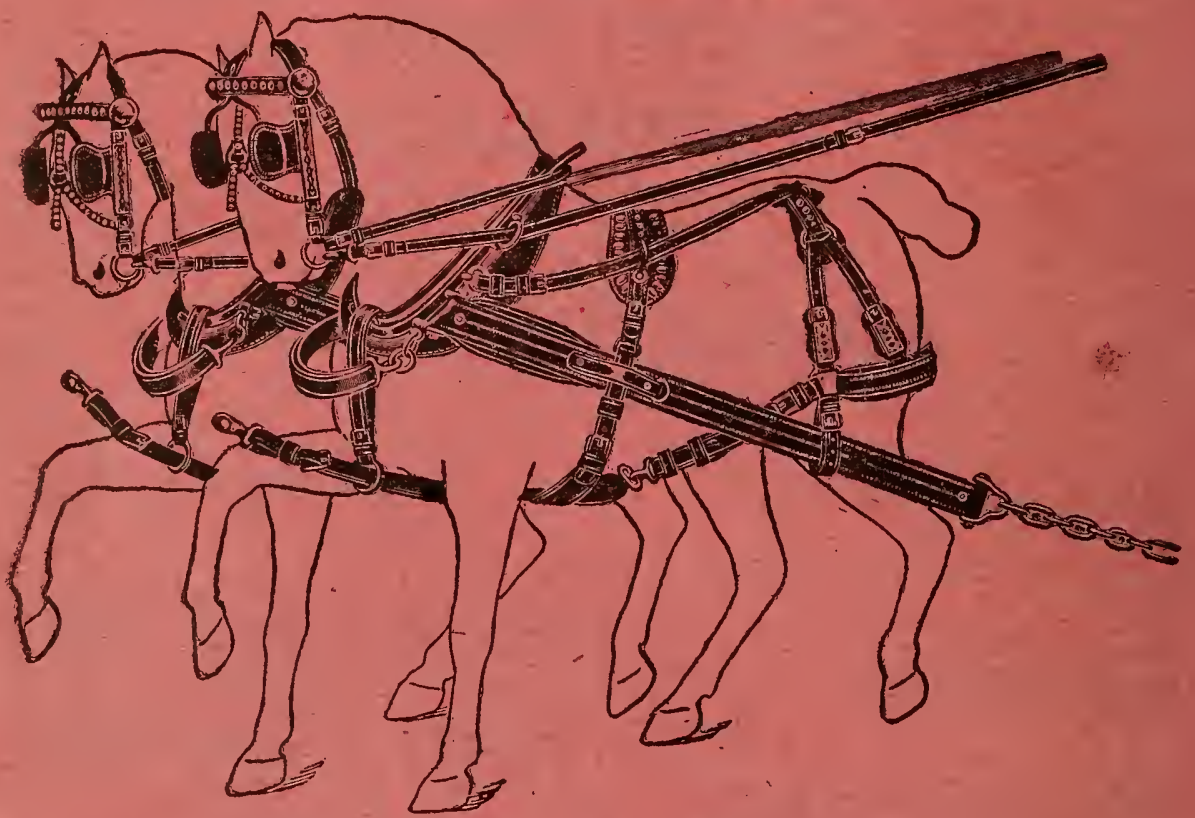

THIS HAND MADE CONCORD FARM HARNESS

$X C$ or Japan and part brass without collars SPECIAL PRICE \$39.75

BRIDLES-7-8 in. spotted fronts, nose bands and blinds, flat checks.

LINES-1 1-8 in. 20-ft. buckles and billets with snaps.

HAMES-Dandy brass balltop, with concord bolt, spread rings.

TRACES-11-2 in. 6-ft. 4-in. heavy: double and stitched with long chafes. $11-2$ in. belly bands, folded.

$B A C K B A N D S-41-2$ in. felt lined, fancy spotted, back-strap bridges.

BACK STRAPS-11-8 in. double, stitched into trace carriers. 3-ring hip tugs. 1-in. double hip straps.

BREECHING-Folded. 11-4 in. layer. 1-in. side and lazy straps

BREAST STRAPS, MARTINGALES, HITCH STRAPS-

All regular size. Wie are offering this fine harness at the low price quoted to show you how we can save you money. Order at once.

\section{Stock Yards Harness Shop. SIOUX CITY. IOWA.}


nor in any way limit or qualify the liability of any corporation or person owning or operating a railway that fails to fence the same against live stock running at large for any stock injured or killed by reason of the want of such fence.

\section{Commission of Animal Health}

SECTION 1. STATE BOARD OF VETERINARY MEDICAL EXAMINERS ABOLISHED-POWERS AND DUTIES TRANSFERRED. That the board known as the state board of veterinary medical examiners is hereby abolished and all of the powers and duties thereof are hereby transferred to and enjoined upon the state veterinary surgeon, except as hereinafter provided. All of the books, documents records stationery and office equipment now in possession of the board or of any officer or employe thereof shall, upon the taking effect of this act be turned over to the state veterinary surgeon.

SEC. 2. COMMISSION OF ANIMAL HEALTH-HOW CON- . STITUTED AND APPOINTED-TERMS. There is hereby created a commission to be known as a commission of animal health, which commission shall consist of the state veterinary surgeon who shall be the chairman and executive officer thereof, two veterinarians and two stock raisers all of whom shall be appointed by the governor. The veterinarians shall possess the same qualifications required for the state veterinary surgeon. One such veterinarian shall be appointed to serve until June 30, 1912 and one until June 30, 1913 and as their terms expire their successol's shall be appointed for three years. The state veterinary surgeon shall be appointed to serve until June 30, 1914 and thereafter his term shall be three vears. The other membsrs of the commission shall be appointed, one to serve until June 30, 1912 and the other until June 30, 1913 and as their terms expire their successors shall be appointed for a term of two years.

SEC. 3. MEETINGS-RULES AND REGULATIONS FOR PREVENTION AND SPREAD OF DISEASE AMONG ANIMALS. The commission shall hold at least two meetings each year one in July and one in January, at the office of the state veterinary surgeon, and may meet at such other times and places in the state as may seem necessary. It shall have the power and authority to make such rules and regulations as it shall deem necessary for the prevention suppression, or against the spread of any contagi $\cdots$ infectious disease among animals in or being driven or transporti through or brought into the state and may provide for quarantining against animals within or without the state. When such rules and regulations have been submitted to and approved by the executive council they shall be published and enforced by the veterinary surgeon and in the performance of his duties he may call to his assistance any peace officer.

SEC. 4. EXAMINING BOARD. The state veterinary surgeon and the two veterinarians upon the commission shall constitute a board for the examination of applicants to practice veterinary medicine, surgery and dentistry in the state.

SEC. 5. COMPENSATION-EXPENSES. The members of the commission other than the state veterinary surgeon, shall receive as compensation for their services one hundred dollars each per annum, together with their actual and necessary traveling, hotel and other expenses and in addition thereto the veterinarians upon the commission shall receive one hundred dollars each per annum for their services as members of the examining board. All of which shall be paid upon vouchers duly approved by the executive council.

SEC. 6. ACTS IN CONFLICT AMENDED. All acts or parts of acts in conflict with the provisions of this act are hereby amended to conform to the provisions hereof. 


\section{Associations for Promotion of Live Stock Industry}

AN ACT to authorize the incorporation in each county of the state of an association for the advancement and improvement of agriculture, animal husbandry and horticulture to define the powers and rights of such association and its members, to provide for the submission to the voters of the question of levying a tax in aid of the objects of such association and to provide for the termination of said tax.

$B e$ it enacted by the General Assembly of the State of Iowa:

SECTION 1. PURPOSE. For the purpose of improving and advancing the science and art of agriculture, animal husbandry and horticulture a boly corporate is hereby authorized in each county in the state.

SEC. 2. CORPORATION-HOW FORMED. Such body corporate may be formed by the acknowledging and filing for record with the county recorder of such county, of articles of incorporation by at least ten farmers, land owners, or other business men of each of the majority of the several townships of the county.

SEC. 3. ARTICLES-FORM. The articles of incorporation shall be as follows: "We the undersigned farmers, land owners and business residents of........................... County, Iowa, do hereby adopt the following articles of incorportation:

Article 1. The objects of this incorporation shall be to advance and improve, in..................... County Iowa, the science and art of agriculture, horticulture and animal husbanclry.

Article 2. The name of this incorporation shall be The Farm Improvement Association of......................... County, Iowa. (Inserting the name of the county of which the incorporators are residents.)

Article 3. The affairs of this incorporation shall be conducted by a president, a vice-president, a secretary and a treasurer, who. shall perform the duties usually pertaining to such positions, and by a board of directors of nine members, all of which officers and directors shall be elected by the members of said incorporation at an annual meeting on the first Monday of January of each year. Not more than two directors shall be residents of the same township, when elected. All officers and directors shall hold their positions for oneyear and until their successors are elected. Wh the said incorporators, have elected the following provisional officers to hold their respective positions until their successors are elected at the annual meeting in the year:

President

Vice-President

Secrétary

Treasurer

Board of Directors:

1.

2

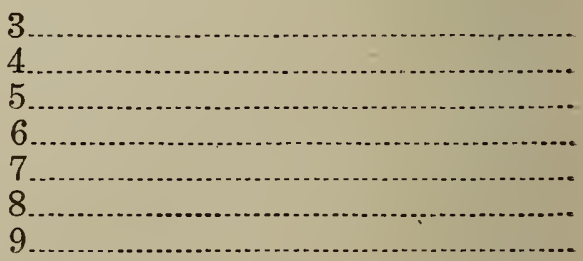

Article 4. The yearly dues of the members of this incorporation shall be one dollar, payable at the time of applying for membership. and on the first Monday in January of each year thereafter. No member having once paid dues, shall forfeit his membership until his or her subsequent dues are six months in arrears.

Article 5. Any citizen of the county and any non-resident owning land in the county shall have the right to become a member of the incorporation by paying one year's dues and thereafter complying with the articles of incorporation and by-laws.

Article 6. This incorporation shall endure until terminated by operation of law. 
SEC. 4. PRIVATE PROPERTY EXEMPT-SEAL. Such body corporate may sue and be sued but the private property of the members shall be exempt from corporate debts. It may have a seal which it may alter at pleasure.

SEC. 5. BY-LAWIS-POWERS-EMPLOY EXPERTS-DUES - HOW EXPENDED. Such body corporate may, in such manner as it may see fit, adopt by-laws; shall have power to take by gift, purchase devise or bequest real and personal property for purposes appropriate to its creation; may employ one or more experts or advisors to advance and improve agriculture, horticulture and animal husbandry in said county, provided that the president of the Iowa state college of agriculture and mechanic arts certifies to the qualifications and fitness of such person to give expert instructions or advice in said sciences. Such body corporate shall have and exercise all powers necessary, appropriate and convenient for the successful carrying out of the objects of said incorporation. The said association shall have authority to use part or all of the sum annually received as dues from its members in the payment of prizes offered in any department of its work including agriculture fairs, short courses or farmer's in stitutes.

SEC, 6. ARTICLES RECORDED. The articles of incorporation shall be recorded by the recorder of deeds without fee of any kind.

SEC. 7. WITHOUT COMPENSATION. No salary or compensation of any kind shall be paid to the president, vice-president, treasurer or to any director.

SEC. 8. NO DIVIDENDS. No dividend shall ever be declared by this incorporation. Any diversion of the funds or property of such incorporation to any purpose except the purposes of incorporation shall constitute larceny and be punished accordingly.

SEC. 9. TREASURER-BOND-AMOUNT. The treasurer: shall give bond, the amount to be fixed by the board of directors in double the amount of money likely to come into his hands with sureties. Said bond shall be filed with and approved by the county auditor and recorded without fee. In no case shall the bond of the treasurel be less than five thousand dollars.

SEC. 10. ANNUAL REPORT. The outgoing president and treasurer shall, on the first Monday of January of each year, file with the county auditor full and detailed reports under oath of all receipts and expenditures of said incorporation, showing from whom received and to whom paid and for what purpose. A duplicate of said report shall also be laid before the members at the annual meeting. The books papers and records of said incorporation shall at all times be open to the inspection of the board of supervisors and to any one appointed by them to make examination.

SEC. 11. TAX LEVY-SUBMITTED TO VOTERS-SEPARATE BALLOT-FORM. Whenever the articles of incorporation are filed as herein provided and the president and secretary certifies to the board of supervisors that the incorporation of said association has bsen effected, the said board shall at the next regular election in said county submit to the voters of said county the question whether a yearly tax of not to exceed five thousand dollars shall be thereafter levied for the purpose of improving and advancing the science and art of agriculture, animal husbandry and horticulture. Said question shall be submitted on a separate ballot and substantially in the following form:

"Shall a yearly tax of not to exceed five thousand dollars be hereafter levied for the purpose of improving and advancing the science and art of agri culture, animal husbandry and horticulture."

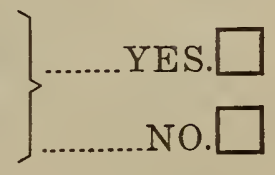


The voter shall signify his vote on said proposition by placing a cross in the square opposite the word "yes or "no."

SEC. 12. VOTE-HOW CANVASSED-LEVY-AMOUNT. The vote on said proposition shall be canvassed and returns made thereof as in other cases and if a majority of the votes are in favor of said proposition the board of supervisors shall prior to the first day of January following said election, set aside, out of the general county fund, the sum of five thousand dollars less any sum advanced to said association by the government of the United States in aid of its objects. Said sum so set aside shall be paid to the treasurer of said association who shall be liable on his bond for the proper distribution thereof. If a majority of the votes be in favor of said proposition, the board of supervisors shall annually thereafter, and at the time of levying taxes gencrally levy on all the property of the county a tax of five thousand dollars, less any amount advanced to said association, by the government of the United States in aid of its objects and at the first general levy of taxes following the advance of funds herein provided, levy an additional tax sufficielit to reimburse said county for the funds so advanced.

SEC. 13. FUNDS-HOW EXPENDED. The treasurer of said incorporation shall receive all funds belonging to said incorporation and all taxes collected as herein provided and shall pay out the same only on bills allowed by the board of directors, such allowance to be certified to by the president or secretary.

SEC. 14. FALSE CERTIFICATE-PENALTY. Any officer making a certificate as provided herein, knowing the same to be false or incorrect in any particular shall be guilty of a misdemeanor and punished accordingly.

SEC. 15. MISUSE OF FUNDS-PENALTY. Any treasurer of such association who in any manner converts the funds or property of such association to his own use or pays out or disposes of the same in any manner different than as directed herein, shall be considered guilty of larceny and punished accordingly.

SEC. 16. AMOUNT ADVANCED BY GOVERNMENT. The president and secretary of said assoication shall prior to the time of making any levy or advancing any funds, as herein provided, certify to the board of supervisors the amount if any, advanced to said association by the government of the United States for the ensuing year in aid of its objects.

SEC. 17. AFTER FIVE YEARS MAY BE DISCONTINUEDHOW. After five successive levies have bden madie hereunder, any one hundred resident land ownrs of the county may petition the board of supervisors to submit to the voters of the county the question of discontinuing the levy herein provided for and upon said petition being found sufficient the said board shall, at the next general election submit, on separate ballot, to the voters, the question whether said levy shall be discontinued. If a majority of the votes be in favor of discontinuing said levy then no farther levies shall be made.

\section{Dairy and Beef Cattle Industry}

SECTION 1. IOWA STATE DAIRY ASSOCIATION. Whenever the organization now existing in the state of Iowa and known as the Iowa State Dairy Association shall have filed with the secretary of the state of Iowa, verified proofs of its organization, the names of its president, vice-president secretary and treasurer and that it has five hundred $(500)$ bona fide members, such association shall be recognized at the Iowa state dairy association of the state of Iowa, and be entitled to the benefits of this act.

SEC. 2. INSPECTION-INSTRUCTION. For the purpose of aiding in the promotion and development of the dairy industry of the 
state of Iowa such association shall cause to be made such inspection: of dairy farms, dairy cattle, dairy barns and other buildings and appliances used in connection therewith, dairy products and methods as. they shall deem best and shall arrange to furnish such instruction and general assistance either by institutes or otherwise, as they deen proper to advance the general interests of the dairy industry: of the state.

SEC. 3. EXECUTIVE COMMITTEE. For all the purposes: of this act the said association shall act by and through an executro committee of five (5 ) members, consisting of the president and saceretary of the Iowa statc dairy association, the dean of the divisiors agriculture of the Iowa state college of agriculture and mechanic arts: and the professor of dairying of the same institution and the dairy and food commissioner of the state of Iowa.

SEC. 4. INSPECTORS AND INSTRUC'TORS-COMPENSAT TION-EXPENSES. They may employ two or more competent per-. sons who shall devote their entire time to such inspection and instruction under the direction of the said executive committee, and who shall hold office at the pleasure of the committee, and who shall each receive a salary not to exceed eighteen hundred dollars $(\$ 1800.00)$; per annum, and actual expenses while engaged in such work.

SEC. 5. ANNUAL REPORT TO THE GOVERNOR. The said association may require such reports from their employes as they deem proper and shall make to the governor an aninual report of their proceedings under this act, which report shall be published. as part of the proceedings of the annual convention of the Iowa state dairy association.

SEC. 6. BEEF CATTLE BREEDER'S ASSOCIATION. Whenever there shall have been filed in the office of the secretary of stote for Iowa, verified proofs of the organization of the beef cattle breeder's association, together with proofs that such association has five hundred $(500)$ bona fide members who are stock breeders or stoek feeders in this state together with the names of the president, vieepresident, secretary and treasurer, such association shall be recognized as the Iowa beef cattle breeders association and be entitled to the benefits of this act.

SEC. 7. -INSTRUCTION-INSPECTION-EXECUTTV BOARD. It shall be the outy of the beef cattle breeders association: to aid in the promotion of the beef cattle industry of the state and to. provide for practical and scientific instruction in the breeding and raising of beef cattle and to provide for the inspaction of herds, premises and appliances, methods and ford stuffs used in the business of feeding, for the purpose of making suggestions and demonstrations berceficial to the business. The said association shall act by and throughe an executive board to be composed of the dean of the division of agriculture of the Iowa state college of agriculture and mechanic arteat Ames and the professor of animal industry of the same institution. and the secretary of the state agricultural society, and the presicient and secretary of the sais Iowa beef cattle breejer's association.

SEC. 8. INSPECTORS AND INSTRUCTORS-COMPENSATION-EXPENSES. The said board may employ two or more competent persons who shall devote their entire time in making inspection and giving instructions as provided in this act under the direction of said board. Such instructors and inspectors shall bold office at the pleasure of the board and shall receive a salary not to exceed eighteen hundred dollars $(\$ 1800.00)$ per annum and actual expenses while engaged in the work.

SEC. 9. SALARIES AND EXPENSES-HOW PAID. The salaries of all persons employed under the provisions of this act shall be paid monthly out of the appropriation herein provided and all traveling expenses and all general expenses incurred by the said as 
sociation in carrying out the purposes of this act shall be paid out of the said appropriation and in the manner provided by sections $170-d$ and 170-e and 170-f of the supplement to the code, 1907, and upon : statements filed with the executive council as therein provided, but no bill shall be paid until after the executive committee of the board under whose authority such expense was incurred shall have audited and approved the bill in such manner as the committee shall provide.

SEC. 10. APPROPRIATION. For the purpose of carrying into -effect the provisions of this act and the payment of all expenses consnected therewith, there is hereby appropriated out of any fund in the

treasury of the state not otherwise appropriated, the sum of fifteen thousand dollars $(\$ 15,000.00)$ or so much thereof as may be necessary to pay the salaries and expense provided for under the provisions of this act provided however, that of the said appropriation, the sum of seven thousand five hundred $(\$ 7,500.00)$ dollars, shall be available for the purpose of paying the expense incurred by the Iowa state dairy association board, and the sum of seven thousand five hundred ( $\$ 7$ 500.00 ) dollars shall be available for the purpose of paying the expenses incurred by the Iowa beef cattle breeder's association board. It being the purpose of this act to provide a fund of seven thousand five hundred $(\$ 7,500.00)$ dollars for the encouragement of the dairy industry and a sum of seven thousand five hunjred $(\$ 7,500.00)$ dolJars for the encouragement of the beef cattle industry in this state.

SEC. 11. FUNDS NOT TO BE USED FOR PRIVATE PURPOSES. None of the money appropriated by this act shall be used to pay the salaries or expense or used in any manner for the private Boenefit of any member of the board of either of said associations.

\section{Registration of Farm Names}

SECTION 1. REGISTRATION OF FARM NAME AUTHORIZED-CERTIFICATE. Any owner of a farm in the state of Iowa may have the name of his farm together with a description of his lands to which said name applies, recorded in a register kept for that purpose in the office of the county recorder of the county in which said farm is located and such recorder shall furnish to such land owner a proper certificate setting forth said name and a description of such lands. That when any name shall have been recorded as the name of any farm in such county, such name shall not Be recorded as the name of any other farm in the same county.

SEC. 2. FEE. Any person having the name of his farm recorded as provided in this act shall firet pay to the county recorder a fee of one dollar, which fee shall be paid to the county treasurer as other fees are paid to the county treasurer by such recorder.

SEC. 3. TRANSFER OF FARM MAY INCLUDE REGISTERED NAME. When any owner of a farm, the name of which has been recorded as provided in this act, transfers by deed or otherwise, the whole of such farm such transfer may include' the registered name thereof; but if the owner shall transfer only a portion of such farm, then in that event, the registered name thereof shall not be transferred to the purchaser unless so stated in the deed of conveyance.

SEC. 4. CANCELLATION OF REGISTERED NAMEFEE. When any owner of a registered farm desires to cancel the registered name there of he shall state on the margin of the record of the register of such name the following: "This name is cancelled and I hereby relcase all rights thereunder" which shall be signed by the person cancelling such name and attested by the county recorder. That for such latter service the county recorder shall charge a fee of twenty-five cents, which shall be paid to the county treasurer as other fees are paid to the county treasurer by him. 


\section{UNITED STATES LAWS AND SANI- "TARY REGULATIONS}

REGULATIONS OF THE SECRETARY OF AGRICULTURE Governing the Inspection, Disinfection, Certification Treatment Handling, and Method and Manner of Delivery and Shipment of Live Stock which is the Subject of Interstate Commerce.

\section{GENERAL REGULATIONS.}

Regulation 1. When the secretary of agriculture shall determine the fact that cattle or other live stock in the state or territory or the District of Columbia are affected with any contagious, infectious, or communicable disease, notice will be given of that fact. A. rule will be issued placing in quarantine all or a portion of the state or territory or the District of Columbia in which the disease exists, and this rule will either absolutely forbid the movement of live stock from the quarantined area or will indicate the regulations under which live stock may be moved therefrom.

Regulation 2. Before ofering cattle or other live stock for transportation, or transporting them, or introducing them into any public stock yards or upon public highway or lines of interstate traffic all persons or corporations owning, managing, or transporting cattle or other live stock are required to exercise reasonable diligence to ascertain that such animals are not affected with any contagious or infectious disease and have not been exposed to the contagion or infection of disease by contact with other animals so diseased or by location in or upon pens, premises caxs or other's vehicles contaminated by diseased animals. All persons having charge of diseased or exposed cattle or other live stock are required to keep them confined and? to permit no other animals to come in contact with them. Premises or vehicles which have contained diseased or exposed cattle or other live stock shall not be occupied by healthy animals until the said premises or vehicles shall have been disinfected as hereinafter provided.

Regulation 3. Cars, boats, and other vehicles that have been used for the interstate transportation of diseased or exposed cattle or other live stock shall be cleaned and disinfected as hereinafter provided, If the facilities for cleaning and disinfecting cars cannot be provided at the point of destination, the railroad company shall seal, bill, and forward the infected cars to a point to be agreed upon between an agent of the company and a representative of the bureau of animal indestry and shall there clean an 1 disinfect the said cars in the presence of an employe of the bureau of animal industry.

Regulation 4. Cars, boats, and other vehicles intended for use in interstate transportation of healthy and non-exposed cattle or other live stock within or from a quarantined area, shall be cleaned and disinfected as hereinafter provioed ur'ess it shall be shown to the satisfaction of the inspector of the bureau of animal industry either that said cars have been cleaned and disinfected according to regulation $3_{2}$ and have not carried or contained animals since that cleaning and disinfection, or that the cars have never been used for the transporportation of diseased or exposed animals.

Regulation 5. Public stock yards, feeding stations and approaches chutes, alleys and pens thereof, which have contained diseased or exposed'animals, shall, before healthy or non-exposed animals are 
7ared therein, be cleaned and disinfected as hereinafter provided. Failure to clean and disinfect will subject the said places to quarantine.

Regulation 6. When, in the opinion of the secretary of agriculture, the shipment or removal of hay straw, forage, or similar material Fram a quarantined area is liable to spread the contagion or infection of ans disease affecting live stock, said shipment or removal will either absolutely prohibited or permitted under restrictions which will Indicated in each particular case.

Regulation 7. When deemed necessary, shipments of live stock and of the articles named in regulation 6 will be stopped in transit, for inspection and disposition and all persons and corporations having control of the transportation of such live stock or articles shall cease the carriage or transit of the same upon receipt of an order from an inspector of the bureau of animal industry, shall submit the 趈 xtock to inspection, and shall disinfect the said articles if requirzed.

Regulation 8. Where, in order to prevent the spread of a disease it becomas necessary to slaughter any diseased or exposed live stock, the value of the live stock shall be ascertained and compensation made therefor, either by agreement with the owner or by appraisement in the manner provided by the law of the state or territory wherein the owryer of the live stock has his legal residence.

Regulation 9. Where inspection and certification are required sy the regulations of the secretary of agriculture, inspection and certification by an inspector of the bureau of animal industry are meant and such inspection and certification will be furnished without the sayment of fees or charges of any nature.

Regulation 10. Live stock shipped from a quarantined area, not accommanied by a certificate of an inspector of the Bureau of Animal Indastry showing freedom from disease or from exposure thereto: shaid not be diverted en route to feed lots or to other states for feeding; stocking, or breeding purposes unless inspected and ecrtified by an inssedtor of the Bureau of Animal Industry.

\section{RETULATIONS TO PREVENT THE SPREAD OF SPLENETIC FEVER OF CATTLE.}

Regulation 11. Whenever any state or territory located within an area quarantined by the secretary of agriculture for epieretic, Southern or Texas fever shall duly establish a stace or territorial quarantine line different from the line established by the secretary of agriculture and shall obtain the legislation requiito to enforce said state or territorial quarantine line strictly and comapletely within the boundaries of said state or territory the secrefary of agriculture will, if the said state or territorial quarantine Wine be satisfactory, adopt by a rule said state or territorial quaransirs 1 ine, and the state or territorial quarantine line as adopted shall defrire the limits of that portion of the quarantined area. The exspirstion of the time fixed in the rule the revocation of the rule, or a 造致hure upon the part of the state officers to enforce the adopted line shail restore the quarantined area to the territory fixed by the secretary of agriculture before the adoption of the state or territorial quarantine line.

Regulation 12. Whenever any state or territory under authority of faw shall establish a state or territorial quarantine line for splenetic fever which differs from the quarantine line established by the secretary of agriculture for the said disease, and shall desire a modification of the line established by the secretary of agriculture, the roreper officer of the said' state or territory shall forward to the secrefary of agriculture a true map or description of such line and a duly authenticated copy of the laws and regulations relating to the establishment and enforcement of said line. 


\section{Snyder, Son}

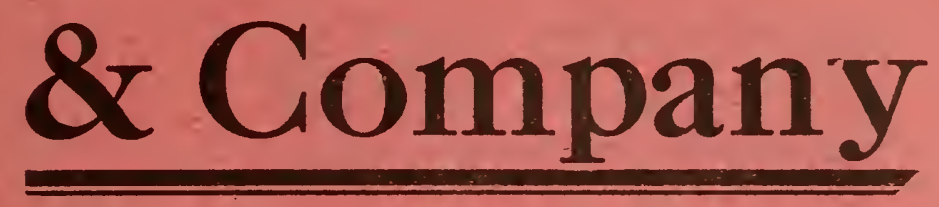

\section{Live Stock}

\section{Commission Merchants}

References:

Live Stock National Bank First National Bank, Doon, Iowa

Iowa State Bank, Hull, Iowa

\section{Order Buying a Specialty}

N. W. SNYDER, Cattle Salesman

J. W. SNYDER, Cattle Salesman

C. M. SNYDER, Hog Salesman

JAMES PETERSON, Sheep Salesman

Auto Phone 2663. Iowa Phone 1286

Room 215 Exchange Building

Sioux City, - - _ Iowa 


\section{STARS AND STRIPES}

\section{BOTTLED BEER}

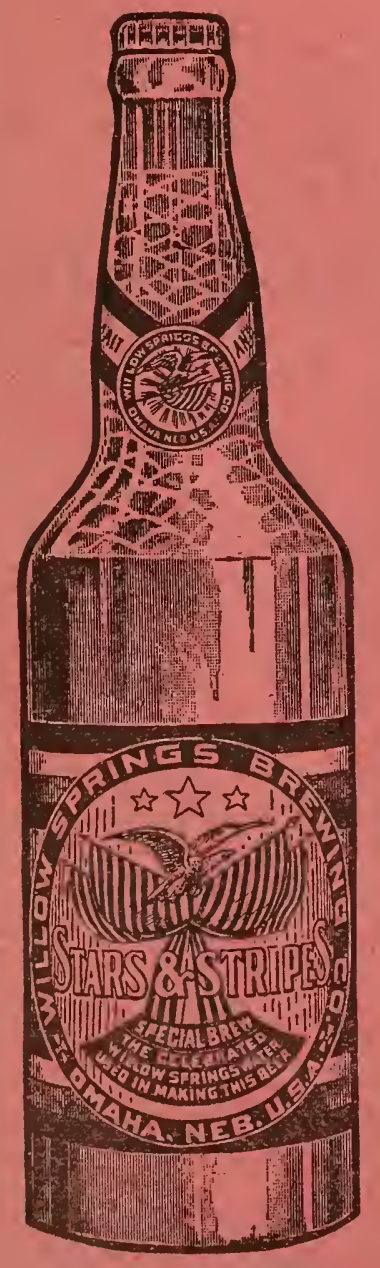

Has no superior and few equals. Made from the most carefully selected hops and the finest malt, together with pure sparkling spring water from the celebrated Willow Springs.

Brewed and bottled in one of the most modern plants in existence.

Don't take our word for it. Order a case and be convinced.

\section{Willow Springs Brewing Co.} Omaha, $\therefore$ Nebraska 
Regulation 13. From the 1st day of February to the 31st day of October, inclusive of each year no cattle shall be transported or driven or allowed to drift from the area quarantined by the secretary of agriculture for splenetic fever into any state or territory or the District of Columbia or portion there of outside of the said quaran: tined area, except as hereinafter provided. During the months of January, November and December of each year cattle from the area quarantined by the secretary of agriculture for splenetic fever may be shipped without restrictions other than those imposed by state or territorial officers at point of destination.

Regulation 14. Cattle from the said quarantined area may be transported at any time by rail or boat, to a recognized slaughtering center outside the quarantined area for immediate slaughter, but cattle shall not be trailed or driven or hauled therefrom in private conveyance. When transported for immediate slaughter the said cattle shall be slaughtered within two weeks after arrival at destination and the following rules regarding their movement shall be observed:

(a) When any cattle in course of transportation from the quarantined area are unloaded, at a point outside of the quarantined area to be fed or watered, or for other purposes said cattle shall be placed in pens or yards reserved for cattle originating in the quarantined area, and a sign shall be conspicuously placed on all such pens or yards with the words "quarantine pens" or "quarantine yards" in letters not less than 10 inches in height. Cattle which have not originated in the quarantined area shall not be admitted into said pens or yards, and if cattle not originating in the quarantined area shall be placed in the said pens or yards said cattle shall thereafter be treated in all respects as if they had actually originated in the.quarantined area.

(b) On unloading said cattle at their points of destination, chutes, alleyways and pens sufficiently isolated and marked with a sign as above, shall be set apart to receive them, and no other cattle shall be admitted to said chutes, pens, and alleyways, and the regulations relating to the movement of cattle from said area, as prescribed by the proper state officers at destination, shall be carefully observed. The cars or boats which have carried said cattle' shall be cleaned and disinfected as hereinafter provided as soon as possible after unloading and before the said cars or boats are again used to transport, store, or shelter live stock or merchandise.

(c) Where cattle originating in the quarantined area and cattle originating outside of the quarantined area are yarded in adjacent pens, there shall bo left a space between the said pens not occupied by cattle, and not less than ten feet wide and there shall be on each side of this space a tight board fence not less than five feet high.

(d) The proper officers of the railroad companies shall affix on both sides of all cars carrying cattle from the quarantined area, except as hereinafter provided, durable printed placards not less than $5 \frac{1}{2}$ by 8 inches in size, the letters of which shall be boldface and not less than $1 \frac{1}{2}$ inches in height. The placard shall state that said cars contain "southern cattle;" and each of the waybills, conductors' manifests, memoranda, and bills of lading of said shipments by cars or boats shall have a statement of similar import plainly written or stamped upon its face. The placard shall state the name of the place from which the shipment was made, with the date and the name of the place of destination; said date must correspond with the date of the waybills and other papers. Whenever any cattle have come from aaid quarantined area and are reshipped from any point at which they have been unloaded to a point other than the original de'stination, or are transferred to another transportation company, the cars carrying said animals shall bear, on both sides, similar placards bearing the same information, which shall be affixed by the officers 
of the said transportation company, and the waybills, conductors" manifests, memoranda, and bills of lading of said shipments by cars or boats shall be so marked. At whatever point these cattle are unloaded they shall be placed in separate pens, as hereinbefore provided.

(e) No car or boat containing cattle from the quarantined area shall receive on board cattle which have originated or which are, at the time of loading, outside of said quarantined area. Cattle from the quarantined area shall not be shipped or transported when consigned to a point outside of said quarantined area where proper facilities have not been provided for transferring the said cattle from the cars or landing to the stock yards and slaughterhouses without passing them over public highways, unless proper permission for such passing is first had and obtained from the proper authorities at point of destination.

(f) The cars and boats used to transport cattle from the quarantined area, and also the chutes, alleyways, and pens not reserved for the exclusive use of such cattle used en route and at points of destination shall be disinfected in the following manner: Remove all litter and manure. This litter and manure may be disinfected by mixing it with lime or saturating it with a five per cent solution of 100 per cent carbolic acid; or, if not disinfected, it shall be stored where no cattle can come in contact with it during the period from February 1 to October 31 inclusive of each year. Wash the cars and the watering and feeding troughs with water until clean. Saturate the entire interior surface of the cars, including the inner surface of the car doors and the fencing, troughs chutes, and floors of the pens with a mixture made of $1 \frac{1}{2}$ pounds of lime and $1 / 4$ pound of 100 per cent carbolic acid to each gallon of water, or with a solution made by dissolving four ounces of chloride of lime to each gallon of water.

(g) Cars which have carried cattle within the quarantined area shall be cleaned and disinfected before being taken out of the said area except when loaded with cattle in the course of transportation for immediate slaughter, in accordance with these regulations.

Regulation 15. Cattle infested with the Boophilus annulatus, orsouthern cattle tick disseminate the contagion of splenetic, southern or Texas, fever, therefore cattle originating outside of the quarantined area which are infested with the Boophilus annulatus ticks shall be considered as infected cattle and shall be subject to the regulations governing the movement of cattle originating in the quarantined area.

Regulation 16. Stock-yard companies receiving cattle infested with the said ticks shall place the said-cattle in pens set aside for the use of cattle originating in the quarantined area and transpor. tation companies are required to clean and disinfect all cars and boats which have contained the infected cattle, in accordance with the requirements of these regulations.

Regulation 17. Cattle which have been properly dipped in Beau. mont crude petroleum, or in other petroleum approved by the secre. tary of agriculture under the supervision of an inspector of the bureau of animal industry, at a dipping station approved by the sec. retary of agriculture, and which have been examined and certified free of infection by the said inspector may be shipped from the quarantined area to any point outside the said area at any time, subject only to such restrictions as may be imposed by state or ter. ritorial officers at points of destination; but such cattle shall be ship. ped in clean, disinfected cars and shall not be driven through the quarantined area or be unloaded therein, except at such points as may be designated in the rules of the secretary of agriculture.

Regulation 18. Before accepting or moving a shipment of cattle 
from that portion of the quarantined area from which, under the rules of the secretary of agriculture cattle may be shipped after inspection, for purposes other than immediate slaughter, to a point out. side the quarantined area transportation companies shall secure a signed statement from each owner or consignor of said cattle, showing the purpose for which the cattle are shipped. In every case this statement shall accompany the waybills.

\section{REGULATIONS TO PREVENT THE SPREAD OF SCABIES IN CATTLE.}

Regulation 19. No cattle which are diseased with scabies shall be shipped or trailed from one state or territory into another state or territory or the District of Columbia, except as hereinafter provided; and no cattle shall be trailed, shipped or otherwise removed, or allowed to drift from a state or territory or portion thereof quarantined for the disease of scabies in cattle into another state or ter. ritory or the District of Columbia, except as hereinafter provided, unless the cattle have been inspected by an inspector of the bureau of animal industry found free of the disease, and are accompanied by a certificate from the said inspector.

The removal of cattle unaccompanied by a certificate of inspec. tion from an inspector of the state or territory or the District of Columbia, or an inspector of the Bureau of Animal Industry, from a quarantined portion of a state or territory or the District of Co. lumbia into a portion of the same state or territory or the District of Columbia, not quarantined, will subject the unquarantined por. tion of the state or territory or the District of Columbia to quaran. tine.

Regulation 20. In states or territories or portions thereof quar." antined by the secretary of agriculture for scabies in cattle those cattle which upon inspection by an inspector of the Bureau of Ani. mal Industry, at the time of shipment, are found to be free from symptoms of scabies shall be given a certificate and allowed to move to points outside the qurantined area for any purpose subject only to such restrictions as may be imposed by the state or territorial officer's at points of unloading and destination; but if a herd or consignment, intended for feeding, breeding or stocking purposes be offered for inspection and shipment and a portion thereof is found to be diseased with scabies or if the cattle offered for inspection and shipment are part of a herd that is known to be so diseased, the diseased cattle offered for shipment shall be dipped twice in either the lime-and-sulphur or the tobacco-and-sulphur dip, or once in Beaumont crude petroleum in the manner hereinafter provided, and the cattle offered for shipment which are not visibly diseased shall be dipped once before shipment.

Regulation 21. Cattle not visibly diseased with scabies may be shipped without inspection from points in the quarantined area to Buffalo, New York; Chicago Illinois; Cincinnati, Ohio; Cleveland, Ohio; Denver, Colorado; Fort Wiorth, Texas; Indianapolis Indiana; Kansas City, Missouri; Kansas City Kansas; Louisville, Kentucky; Milwaukee, Wisconsin; National Stock Yards, Illinois; South Omaha Nebraska; Sioux City, Iowa; South St. Joseph, Missouri ; St. Louis, Missouri; South St. Paul, Minnesota, or to any other market or slaughtering center where inspection is maintained and where facilities are available for either dipping or slaughtering cattle under the supervision of this Department. When so shipped the cattle shall be submitted for inspection at destination and when found upon such inspection to be free from disease and exposure thereto, en route no further restriction shall be placed upon them. If found upon inspection to be infected, they shall not be permitted further shipment until treated as heretofore prescribed for diseased cattle.

When cattle are shipped without inspection under the terms of 
this regulation, the employees of the transportation company shall affix to both sides of each car a durable conspicuous printed placard not less than $5 \frac{1}{2}$ by 8 inches in size, the letters of which shall be boldface and not less than $1 \frac{1}{2}$ inches in height. These placards shall bear the words, "Uninspected Cattle" and shall not be removed until the cattle have arrived at destination and the inspector has indicated the disposition to be made of the cars. The waybills, conductors' manifests, memoranda, and bills of lading of said shipment shall also bear the notation "Uninspected cattle."

Regulation 22. Cattle diseased with scabies which have been dipped once in either the lime-and-sulphur or the tobacco-and-sulphur dip in the manner hereinafter provided, under the supervision of an inspector of the Bureau of Animal Industrv, within ten days of date of shipment, and cattle not visibly diseased, but which are known to be a part of a diseased herd, may be shipped for immediate slaughter to a recognized slaughtering center, and when so shipped the said cattle shall not be diverted enroute, and shall be slaughtered within two weeks after arrival at destination. If cattle diseased with scabies are to be shipped for stockers or feeders they shall be dipped twice in either the lime-and-sulphur or the tobacco-and sulphur dip ten days apart or once in Beaumont crude petroleum, uncer supervision, and shall be submitted to inspection before shipment. Cattle not visibly diseased, but which are known to be part of a diseased herd, intended for stockers or feeders, shall be dipped once before shipment. However, diseased cattle may be dipped once in either the lime-and-sulphur or the tobacco-and-sulphur dip under the supervision of an inspector of the Bureau of Animal Industry at the point of origin and shipped for stocking or feeding purposes, if arrangements have been made for the second dipping en route or at destination at the required time after the first dipping at a point where there is an inspector stationed, and under his supervision. Cattle not visibly diseased, but which are known to be part of a diseased herd, shipped to another state or territory, for feeding or stocking purposes, may be dipped en route instead of at point of origin by special permission first had and obtained from the chief of the Bureau of Animal Industry.

Regulation 23. Healthy cattle in a state or territory not quarantined by the secretary of agriculture for scabies in cattle may be shipped in clean cars without inspection into any other state or territory for slaughter or for stockers or feeders, but if the said cattle be unloaded en route or at destination and are placed in infected premises, they shall be treated as exposed cattle, and shall not be forwarded to destination for purposes other than for immediate slaughter, until they shall have been dipped once in any dip herein approved under the supervision of an inspector of the bireau of animal industry.

Regulation 24. When either diseased cattle that have been dipped once in the lime-and-sulphur or the tobacco-and-sulphur dip, or cattle not visibly diseased, but which are known to be a part of a diseased herd, are shipped in accordance with Regulation 22, the employes of the transportation company shall affix to both sides of each car a durable conspicuous, printed placard, not less than $5 \frac{1}{2}$ by 8 inches in size, the letters on which shall be boldface, and not less than $1 \frac{1}{2}$ inches in height. These placards shall bear the words, "Dipped Scabby Cattle," or "Cattie Exposed to Scabies," and shall not be removed until the cattle have arrived at destination or point of dipping, have been unloaded, and the cars have been disinfected. The waybills, 
conductors' manifests, memoranda, and bills of lading of said shipment shall also bear the notation, to be affixed by the transportation company, "Dipped Scabby Cattle" or "Cattle Exposed to Scabies."

Regulation 25. The dips now approved by the department are the lime-and-sulphur dip, the tobacco-and-sulphur dip, and Beaumont crude petroleum. The lime-and-sulphur dip is made in the proportion of 12 pounds of unslaked lime and 24 pounds of flowers of sulphur to 100 gallons of water. Weigh both the lime and sulphur. Place the unslaked lime in a mortar box or some suitable vessel and add enough water to slake the lime and form a lime paste or lime putty. Sift into this lime paste the flowers of sulphur and stir the mixture well. To make 100 gallons of dip, place the sulphur and lime paste in a kettle or boiler with about thirty gallons of boiling water and boil the mixture for two hours at least, stirring the liquid and seliment; add enough water when necessary to maintain the quantity. Draw the mixture and sediment into a large tub or barrel placed near the dipping vat and provided with a bunghole about four inches from the bottom, and allow ample time to settle-from two to three hours or more, if necessary. When fully settled, draw off the clear liquid into the dipping vat and add enough warm water to make 100 gallons. The same directions apply to larger quantities of dip, proportionate amounts of ingredients being used.

The tobacco-and-sulphur dip is made with sufficient extract of tobacco or nicotine solution to give a mixture containing not less than five one-hundredths of one per cent. of nicotine and two per cent. flowers of sulphur.

When Beaumont crude petroleum is used as a dip for cattle diseased with or exposed to scabies, one dipping only is necessary in any case, and the cattle shall be submerged but once and shall not be held in the dip.

The dipping shall be done thoroughly. When either the limeand-sulphur or the tobacco-and-suiphur dip is used, the cattle shall be held in the dip two minutes unless the diseased cattle shall have been hand-dressed previously. The cattle shall be completely submerged twice. The dip shall be maintained as nearly as possible at a temperature of $105 \mathrm{deg}$. F. while the cattle are in it. It shall be renewed as soon as it becomes filthy, regardless of the number of cattle that have been dipped in it, and in no case shall it be used when more than one week old. In emptying the dipping vat the entire contents shall be removed. including all sediment and droppings or other foreign matter. The department assumes no responsibility for loss or damage resulting from the dipping.

Regulation 26. Cattle shipped under a certificate from an inspector of the bureau of animal industry are not guaranteed uninterrupted transit; for, in the event of the development of scabies or exposure to the disease en route, the cattle shall then be handled as diseased or exposed cattle and shall be dipped as hereinbefore provided and the cars or other vehicles and the chutes, alleys, and pens which have been occupied by them shall be cleaned and disinfected.

Regulation 27. Public stock yards shall be considered infected and the cattle yarded therein as having been exposed to the disease, and no cattle shall be removed from said public stock yards, except for immediate slaughter, without dipping. Where, however, a part or all of the stock yards is reserved and set apart for the reception of uninfected shipments of cattle and is kept free of disease, cattle may be shipped from the said uninfected yards or portions thereof without dipping. If diseased cattle are introduced into said uninfected yards or portions thereof, they shall be immediately removed therefrom and the chutes, alleys, and pєns used by them thoroughly cleaned and disinfected. No cattle shall be forwarded for feeding. 
or stocking purposes from any stock yards where an inspector of the bureau of animal industry is stationed without a certificate of inspection or of dipping issued by the said inspector.

Regulation 28. Cars and other vehicles yards, pens, sheds, chutes, etc., which have contained diseased cattle shall be cleaned and disinfected immediately after the cattle are removed therefrom in the following manner: Remove all litter. and manure and then saturate the interior surfaces of the cars and woodwork, flooring, and ground of the chutes, alleys, and pens with a five per cent. solution of 100 per cent. carbolic acid in water with sufficient lime to show where it has been applied.

\section{REGULATIONS TO PREVENT THE SPREAD OF SCABIES IN SHEEP.}

Regulation 29. No sheep which are diseased with scabies shall be shipped or trailed from one state or territory into another state or territory, or the District of Columbia, except as hereinafter provided and no sheep shall be trailed or shipped from a state or territory or portion thereof quarantined for the disease of scabies in sheep into another state or territory or the District of Columbia, except as hereinafter provided, until the sheep have been inspected by an inspector of the bureau of animal industry, found free of the disease and of exposure thereto, and are accompanied by a certificate from the said inspector. For the purpose of these regulations all of the sheep in a certain flock or shipment in which the disease is present shall be considered discased, and none of the sheep in the said diseased flock or shipment shall be removed or offered for shipment until dipped, as hereinafter provided. The practice of "picking" a flock-i. e., removing sheep which are visibly diseased and then offering any portion of the remaining sheep for either inspection or shipments or both-is directly and positively prohibited.

Regulation 30. Healthy sheep in an area are not quarantined for the disease of scabies in sheep which have not been exposed to the disease may be shipped or trailed without restriction by the regulations of the secretary of agriculture to prevent the spread of scabies in sheep, but if the said sheep be unloaded, en route or at destination and are placed in infected premises they shall be treated as exposed sheep and shall not be forwarded to destination for purposes other than immediate slaughter until they shall have been dipped under the supervision of an inspector of the bureau of animal industry.

Regulation 31. Sheep that are diseased with scabies and which have been dipped once in the manner hereinafter provided, under the supervision of an inspector of the bureau of animal industry, within ten days of date of shipment. may be shipped for immediate slaughter to a recognized slaughtering center, and when so shipped the said sheep shall not be diverted en route and shall be slaughtered within two weeks after arrival at destination. If the diseased sheep are to be shipped for stocking or feeding purposes they shall be dipped twice, as above indicated, ten days apart, and shall be submitted to inspection before shipment.

Sheep that are not diseased with scabies, but which have been exposed to the contagion of the disease, may be moved for freding or stocking purposes after one dipping, or they may be shipped by rail or boat to a recognized slaughtering center, for immediats slaughter without dipping.

Regulation 32. When diseased sheep have been dipped once and are shipped for slaughter in accordance with regulation 31 , the officers of the transportation company shall affix to both sides of each car a durable, conspicuous, printed placard not less than $5 \frac{1}{2}$ by 8 inches in size, the letters of which shall be boldface, and not 
less than $1 \frac{1}{2}$ inches in height. These placards shall bear the words, "dipped and scabby sheep," and shall not be removed until the sheep have arrived at destination, have been unloaded, and the cars disinfected.

When exposed sheep are shipped without dipping for immediate slaughter, in accordance with regulation 31 , the officers of the transportation company shall affix to both sides of each car a durable, conspicuous, printed placard not less than $5 \frac{1}{2}$ by 8 inches in size the letters of which shall be boldface and not less than $11 / 2$ inches in height, bearing the words "exposed sheep for slaughter."

Regulation 33. The dips now approved are:

(a) The tobacco-and-sulphur dip, made with sufficient extract of tobacco or nicotine solution to give a mixture containing not less than five one-hundredths of one per cent. of nicotine and two per cent. flowers of sulphur.

(b) The lime-and-sulphur dip, made with eight pounds of unslaked lime and twenty-four pounds of flowers of sulphur to 100 gallons of water. The lime and sulphur should be boiled together for not less than two hours, and all sediment allowed to subside before the liquid is placed in the dipping vat.

Either one of these dips may be used.

Regulation 34. The dipping shall be done carefully and the sheep handled as humanely as possible. The department, however, assumes no responsibility for loss or damage resulting from the dipping, and those who wish to avoid any risks that may be incident to dipping at the stock yards as well as to avoid liability to prosecution should see that their sheep are free from disease before shipping them to market.

Regulation 35. The sheep shall be kept in the dip between two and three minutes and their heads be submerged at least once, though but for an instant at a time, and assistance should be rendered immediately if the sheep appear to be strangling. The dip shall be maintained at a temperature of between $100 \mathrm{deg}$. and $105 \mathrm{deg}$. F. while the sheep are in it. It shall be renewed as soon as it becomes filthy, regardless of the number of sheep dipped and in no case shall the dip be used when mores than one week old. In emptying the dipping vat the entire contents shall be removed, including all sediment and droppings, or other foreign matter. Suitable dripping platforms and drying pens shall be provided. Sheep shall not be loaded until they have' become dry.

Regulation 36. Sheep shipped under a certificate are not guaranteed uninterrupted transit; for in the event of the development of scabies or exposure thereto en route they shall be dipped before proceeding to their destination, and the cars or other vehicles and the chutes. alleys and pens that may have been occupied shall be cleaned and disinfected as hereinafter provided.

Regulation 37. Public stock yards shall be considered infected and the sheep yarded therein as having been exposed to the disease, and no sheep may be shipped from said yards except for immediate slaughter, without dipping. Where, however, a part or all of the stock yards is reserved and set apart for the reception of uninfected shipments of sheep and is kept free of disease sheep may be shipped from the reserved yards or portions therenf without dipping. If diseased sheep are introduced into said uninfected yards or portions thereof they shall be immediately removed therefrom and the chutes, alleys and pens occupied by the said sheep shall be thoroughly cleaned and disinfected. No sheep shall be shipped for feeding or stocking purposes from any stock yards where an inspector of the bureau of animal industry is stationed without a certificate of inspection or of dipping issued by the said inspector.

Regulation 38. Cars and other vehicles, yards, pens, sheds, 
chutes, etc., that have contained diseased or exposed sheep shall be cleaned and disinfected in the following manner: Remove all litter and manure, and then saturate the interior surfaces of the cars and the woodwork, flooring, and ground of the chutes, alleys, and pens with a 5 per cent, solution of 100 per cent, carbolic acid in water, with sufficient lime to show where it has been applied.

\section{REGULATIONS 'TO PREVENT THE SPREAD OF MALADIE DU COIT.}

Regulation 39. No horses, or asses shall be offered for shipment shipped, transported, driven or trailed, or otherwise removed or allowed to drift from an area quarantined by the secretary of agriculture for maladie du coit without inspection and certification of freedom from the disease for the purpose of the particular movement by an inspector of the bureau of animal industry. Owners and custodiians of horses or asses for whom inspection is made, shall provide such reasonable facilities and render such assistance as may be required by the inspector.

Regulation 40. Any animal or animals showing symptoms of the disease or known to have been exposed thereto shall, in the discretion of the inspector or employee of the bureau of animal industry, either be immediately quarantined and maintained in quarantine at the expense of the owner or owners until released by the said inspector or employee, or shall be condemned and killed as hereinafter provided.

Regulation 41. No stallion or jack shall be allowed to run at large on the Pine Ridge and Rosebud Indian reservations in the state of South Dakota, and all the stallions and jacks thereon shall be tagged as hereinafter provided.

Regulation 42. There shall be no breeding of animals on the said reservations in a herd in which there is an animal which has been exposed to the infection of maladie du coit within eighteen months after the said exposure.

Regulation 43. When it is necessary, in order to prevent the spread of the disease and to aid in its extermination the Department of Agriculture will purchase a diseased or exposed animal at a price based upon its actual value for work purposes at the time of purchase. When, however, the owner or owners will not accept the indemnity price offered by the department, the inspector shall arrange for a board of three appraisers, who shall determine the price to be paid for the condemned animal. This board shall be constituted as follows: An inspector or other employe of the bureau of animal industry, one person chosen by the owner of the animal or animals to be appraised, and the third member to be chosen by the two herein provided for. The animal or animals under condemnation shall be maintained in quarantine at the expense of the owner or owners until disposed of.

Regulation 44. Any stallions or jacks found running at large on the Pine Ridge and Rosebud Indian reservations on and after the date of this order may be castrated by an inspector or other employe of the bureau of animal industry of this department or by such other person as may be duly authorized by the inspector in charge of the district named, and no in Jemnity shall be allowed the owner in case of damage resulting from such castration. The terms "stallion" and "jack" shall be understood to apply to any uncastrated male horse or ass one year of age or over.

Regulation 45. Each stallion or jack on the above named reservations shall bear a numbered tag and shall be kept under such restrictions as the inspector in charge shall prescribe, and shall be subjected to examination at such times and as frequently as may be thought necessary by the inspector, for the purpose of ascertaining whether symptoms of the disease have developed. 
Regulation 46. The department will pay a sum of $\$ 50$ for authentic information leading to the discovery of the ownership and location of a stallion or a jack affected with the contagious venereal disease known as maladie du coit, and the sum of $\$ 25$ for authentic information leading to the discovery of the ownership and location of a female animal affected with the disease: Provided, That when such information is received from more than one person as to the location of the same animal and owner, the sum above named shall be paid to the first informant, and when doubt exists or a dispute arises as to who was the first informant no reward shall be paid. When more than one diseased animal is found belonging to the same owner or on the same premises, only one reward shall be paid.

\section{REGULATION TO PREVENT THE SPREAD OF HOG CHOLERA AND SWINE PLAGUE.}

Regulation 47. No swine which are diseased with hog cholera or swine plague, or which have been exposed to either of the diseases by contact with diseased animals or by confinement in infected cars, pens, or other premises, shall be transported, trailed or driven from one state or territory into another state or territory or the District of Columbia, except as hereinafter provided. All persons intending to ship swine shall ascertain before offering them for shipment that the animals are not diseased and have not been exposed to the contagion of either disease.

Regulation 48. Swine which are not diseased with hog cholera or swine plague and which have not been exposed to the infection thereof may be shipped from one state or territory or the District of Columbia, into another state or territory or the District of Columbia without restriction by the regulations of the secretary of agriculture, and subject only to such restrictions as may be imposed on the shipment by state or territorial or District of Columbia officers at destination.

Regulation 49. Public stock yards shall be considered infected and no swine shall be shipped therefrom for feeding or stocking purposes. No diseased swine shall be shipped from the stock yards, but shall be slaughtered, subject to condemnation on postmortem inspection; and all swine in a certain lot or shipment shall be considered diseased when one or more of them show evidence of the disease. Swine that are not diseased and have been merely exposed by being in the yards may be shipped to a recognized slaughtering center for immediate slaughter. Where, however, a part of the yard is set apart for the reception of uninfected shipments of swine and is kept free of infection, swine may be shipped from such part without restriction. Should such part be contaminated by the introduction of diseased swine, said animals shall be immediately removed therefrom, and the chutes, alleys and pens occupied by them thoroughly cleaned and disinfected as hereinafter provided.

Regulation 50. Cars and other vehicles and pens or yards which have contained diseased or exposed swine shall be cleaned and disinfected as soon as possible after unloading. Cars shall not be removed before the inspector has had time to ascertain the condition of the animals and to give notice that the cars must be cleaned and disinfected. Cleaning and disinfection shall be done by first removing all litter and manure and then saturating the interior surfaces of the cars and the woodwork, flooring and ground of the chutes, alleys and pens with a five per cent. solution of 100 per cent. carbolic acid in water, with sufficient lime to show where it has been applied. 


\section{(Public No. 41.)}

An act for the establishment of a Bureau of Animal Industry, to prevent the exportation of diseased cattle, and to provide means for the suppression and extirpation of pleuro-pneumonia and other contagious diseases among domestic animals.

Be it enacted by the Senate and House of Representatives of the United States of America in Congress assembled:

That the Commissioner of Agriculture shall organize in his department a bureau of animal industry, and shall appoint a chief thereof who shall be a competent veterinary surgeon, and whose duty it shall be to investigate and report upon the condition of domestic animals of the United States, their protection and use, and also inquire into and report the causes of contagious, infectious, and communicable diseases among them, and the means for the prevention and cure of the same, and to collect such information on these subjects as shall be valuable to the agricultural and commercial interests of the country; and the commissioner of agriculture is hereby authorized to employ a force sufficient for this purpose, not to exceed twenty persons at any one time. The salary of the chief of said bureau shall be three thousand dollars per annum; and the commissioner shall appoint a clerk for said bureau, with a salary of one thousand five hundred dollars per annum.

Sec. 2. That the commissioner of agriculture is authorized to appoint two competent agents, who shall be practical stock raisers or experienced business men familiar with questions pertaining to commercial transactions in live stock, and whose duty it shall be, under the instructions of the commissioner of agriculture, to examine and report upon the best methods of treating, transporting and caring for animals, and the means to be adopted for the suppression and extirpation of contagious pleuro-pneumonia, and to provide against the spread of other dangerous, contagious, infectious and communicable diseases. The compensation of said agents shall be at the rate of ten dollars per diem, with all necessary expenses while engaged in the actual performance of their duties under this act when absent from their usual place of business or residence as such agent.

Sec. 3. That it shall be the duty of the commissioner of agriculture to prepare such rules and regulations as he may deem necessary for the speedy and effectual suppression and extirpation of said diseases, and to certify such rules and regulations to the executive authority of each state and territory and invite said authorities to co-operate in the execution and enforcement of this act. Whenever the plans and methods of the commissioner of agriculture shall be accepted by any state or territory in which pleuro-pneumonia or other contagious, infectious, or communicable diseases is declared to exist, or such state or territory shall have adopted plans and methods for the suppression and extirpation of said diseases, and such plans and methods shall be accepted by the commissioner of agriculture, and whenever the governor of a state or other properly constituted authorities signify their readiness to co-operate for the extinction of any contagious, infectious, or communicable disease in conformity with the provisions of this act, the commissioner of agriculture is hereby authorized to expend so much of the money appropriated by this act as may be necessary in such investigations, and in such disinfection and quarantine measures as may be necessary to prevent the spread of the disease from one state or territory into another.

Sec. 4. That in order to promote the exportation of live stock from the United States the commissioner of agriculture shall make 
special investigation as to the existence of pleuro-pneumonia. or any contagious, infectious, or communicable diseaze, along the dividing lines between the United States and foreign countries, and along the lines of transportation from all parts of the United States to ports from which live stock are exported, and make report of the results of such investigation to the secretary of the treasury, who shall, from time to time, establish such regulations concerning the exportation and transportation of live stock as the results of said investigations may require.

Sec. 5. That to prevent the exportation from any port of the United States to any port in a foreign country of live stock affected with any contagious, infectious, or communicable disease, and especially pleuro-pneumonia, the secretary of the treasury be, and he is hereby, authorized to take such steps and adopt such measures, not inconsistent with the provisions of this act, as he may deem necessary.

Sec. 6. That no railroad company within the United States, or the owners or masters of any steam or sailing or other vessel or boat, shall receive for transportation or transport from one state or territory to another, or from any state into the District of Columbia, or from the district into any state, any livestock affected with any contagious, infectious. or communicable disease, and especially the disease known as pleuro-pneumonia; nor shall any person, company, or corporation deliver for such transportation to any railroad company, or master or owner of any boat or vessel, any live stock, knowing them to be affected with any contagious, infectious, or communicable disease; nor shall any person, company, or corporation drive on foot or transport in private conveyance from one state or territory to another, or from any state into the District of Columbia, or from the District of Columbia into any state, any live stock, knowing them to be affected with any contagious, infectious, or communicable disease and especially the disease known as pleuro-pneumonia; Provided, That the so-called splenetic, or Texas, fever shall not be considered a contagious, infectious, or communicable disease within the meaning of sections four, five, six, and seven of this act, as to cattle being transported by rail to market for slaughter, when the same are unloaded only to be fed and watered in lots on the way thereto.

Sec. 7. That it shall be the duty of the commissioner of agriculture to notify, in writing, the proper officials or agents of any railroad, steamboat, or other transportation company doing business in or through any infected locality, and by publication in such newspapers as he may select, of the existence of said contagion; and any person or persons operating any such railroad, or master or owner of any boat or vessel, or owner or custodian of or penson having control over such cattle or other live stock within such infected district, who shall knowingly violate the provisions of section six of this act, shall be guilty of a misdemeanor, and upon conviction shall be punished by a fine of not less than one hundred dollars nor more than five thousand dollars, or by imprisonment for not more than one year, or by both such fine and imprisonment.

Sec. 8. That whenever any contagious, infectious or communicable disease affecting domestic animals, and especially the disease known as pleuro-pneumonia, shall be brought into or shall break out in the District of Columbia, it shall be the duty of the commissioners of said district to take measures to suppress the same promptly and to prevent the same from spreading and for this purpose the said commissioners are hereby empowered to order and require that any premises, farm or farms, where such disease exists, or has existed, be put in quarantine; to order all or any animals coming into the district to be detained at any place or places for the purpose of inspection and ex- 
amination; to prescribe regulations for and require the destruction of animals affected with contagious, infectious, and communicable disease, and for the proper disposition of their hides and carcasses; to prescribe regulations for disinfection and such other regulations as they may deem necessary to prevent infection or contagion being communicated, and shall report to the commissioner of agriculture whatever they may do in pursuance of the provisions of this section.

Sec. 9. That it shall be the duty of the several United States district attorneys to prosecute all violations of this act which shall be brought to their notice or knowledge by any person making the complaint under oath; and the same shall be heard before any District or Circuit Court of the United States or territorial court holden within the district in which the violation of this act has been committed.

Sec. 10. That the sum of one hundred and fifty thousand dollars to be immediately available, or so much thereof as may be necessary is hereby appropriated, out of any moneys in the treasury not otherwise appropriated, to carry into effect the provisions of this act.

Sec. 11. That the commissioner of agriculture shall report annually to Congress, at the commencement of each session, a list of the names of all persons employed, an itemized statement of all expenditures under this act, and full particulars of means adopted and carried into effect for the suppression of contagious, infectious, or communicable diseases among domestic animals.

Approved, May 29, 1884.

(Public-No. 49.)

An Act to enable the Secretary of Agriculture to more effectually suppress and prevent the spread of contagious and infectious disseases of live stock, and for other purposes.

Be it Enacted by the Senate and House of Representatives of the United States of America, in Congress assembled:

That, in order to enable the secretary of agriculture to effectually suppress and extirpate contagious pleuro-pneumonia, foot-and-mouth disease, and other dangerous contagious, infectious, and communicable diseases in cattle and other live stock, and to prevent the spread of such diseases, the powers conferred on the secretary of the treasury by sections four and five of an act entitled "An act for the establishment of a bureau of animal industry, to prevent the exportation of diseased cattle and to provide means for the suppression and extirpation of pleuro-pneumonia and other contagious diseases among domestic animals," approved May twenty-ninth, eighteen hundred and eighty-four (twenty-third United States Statutes, thirty-one), are hereby conferred on the secretary of agriculture, to be exercised exclusively by him. He is hereby authorized and directed from time to time, to establish such rules and regulations concerning the exportation and transportation of live stock from any place within the United States where he may have reason to believe such diseases may exist into and through any state or territory, including the Indian Territory, and into and through the District of Columbia and to foreign countries as he may deem necessary, and all such rules and regulations shall have the force of law. Whenever any inspector or assistant inspector of the bureau of animal industry shall issue a certificate showing that such officer had inspected any cattle or other live stock, which were about to be shipped, driven, or transported from such locality to another, as above stated, and had found them free from Texas or splenetic fever infection, pleuro-pneumonia, foot-and-mouth disease, or any other infectious, contagious, or communicable disease, such animals so inspected and certified may be shipped, driven or transported from such place into and through any state or territory, including the Indian Territory, and into and through the District of 
Columbia, or they may be exported from the United States without further inspection or the exaction of fees of any kind, except such as may at any time be ordered or exacted by the secretary of agriculture; and all such animals shall at all times be under the control and supervision of the bureau of animal industry of the Agricultural Department for the purposes of such inspection.

Sec. 2. That the secretary of agriculture shall have authority to make such regulations and take such measures as he may deem proper to prevent the introduction or dissemination of the contagion of any contagious, infectious or communicable disease of animals from a foreign country into the United States, or from one state or territory of the United States or the District of Columbia to another and to seize, quarantine, and dispose of any hay, straw, forage or similar material, or any meats, hides, or other animal products coming from an infected foreign country, to the United States, or from one state or territory or the District of Columbia in transit to another state or territory or the District of Columbia whenever in his judgment such action is advisable in order to guard against the introduction or spread of such contagion.

Sec. 3. That any person, company, or corporation knowingly violating the provisions of this act or the orders or regulations made in pursuance thereof, shall be guilty of a misdemeanor. and on conviction shall be punished by a fine of not less than one hundred dollars nor more than one thousand dollars, or by imprisonment not more than one year, or by both such fine and imprisonment.

Approved, February 2, 1903.

\section{(Public-No. 229.)}

An Act to enable the secretary of agriculture to establish and maintain quarantine districts, to permit and regulate the movement of cattle and other live stock therefrom, and for other purposes.

Be it Enacted by the Senate and House of Representatives of the United States of America in Congress assembled:

That the secretary of agriculture is authorized and directed to quarantine any state or territory or the District of Columbia, or any portion of any state or territory or the District of Columbia, when he shall determine the fact that cattle or other live stock in such state or territory or District of Columbia are affected with any contagious, infectious or communicable disease; and the secretary of agriculture is directed to give written or printed notice of the establishment of quarantine to the proper officers of railroad, steamboat, or other transportation companies doing business in or through any quarantined state or territory or the District of Columbia, and to publish in such newspapers in the quarantined state or territory or the District of Columbia, as the secretary of agriculture may select, notice of the establishment of quarantine.

Sec..2. That no railroad company-or the owners or masters of any steam or sailing or other vessel or boat shall receive for transportation or transport from any quarantined state or territory or the District of Columbia, or from the quarantined portion of any state or territory or the District of Columbia, into any other state or territory or the District of Columbia, any cattle or other live stock, except as hereinafter provided; nor shall any person, company or corporation deliver for such transportation to any railroad company, or to the master or owner of any boat or vessel any cattle or other live stock except as hereinafter provided; nor shall any person, company, or corporation drive on foot, or cause to be driven on foot, or transport in private conveyance or cause to be transported in private conveyance, from a quarantined state or territory or the District of Columbia, or from the quarantined portion of any state or territory or the District of Columbia, into any other state or territory, or the 
District of Columbia, any cattle or other live stock, except as hereinafter provided.

Sec. 3. That it shall be the duty of the secretary of agriculture, and he is hereby authorized and directed, when the public safety will permit, to make and promulgate rules and regulations which shall permit and govern the inspection, disinfection, certification, treatment, handling, and method and manner of delivery and shipment of cattle or other live stock from a quarantined state or teriitory or the District of Columbia, and from the quarantined portion of any state or territory or the District of Columbia, into any other state or territory or the District of Columbia; and the secretary of agriculture shall give notice of such rules and regulations in the manner provided in section two of this act for notice of establishment of quarantine.

Sec. 4. That cattle or other live stock may be moved from a quarantined state or territory or the District of Columbia, or from the quarantined portion of any state or territory or the District of Columbia, into any other state or territory or the District of Columbia, under and in compliance with the rules and regulations of the secretary of agriculture, made and promulgated in pursuance of the provisions of section three of this act; but it shall be unlawful to move or to allow to be moved, any cattle or other live stock from any quarantined state or territory or the District of Columbia, or from the quarantined portions of any state or territory, or the District of Columbia, into any other state or territory or the District of Columbia, in manner or method or under conditions other than those prescribed by the secretary of agriculture.

Sec. 5. That every person who forcibly assaults, resists, opposes, prevents, impedes, or interferes with any officer or employe of the bureau of animal industry of the United States Department of Agriculture in the execution of his duties, or on account of the execution of his duties, shall be fined not less than one hundred dollars nor more than one thousand dollars, or be imprisoned not less than one month nor more than one year, or by both such fine and imprisonment; and every person who discharges any deadly weapon at any officer or employe of the bureau of animal industry of the United States Department of Agriculture, or uses any dangerous or deadly weapon in resisting him in the execution of his duties, with intent to commit a bodily injury upon him or to deter or prevent him from discharging his duties, or on account of the performance of his duties, shall upon conviction, be imprisoned at hard labor for a term not more than five years or fined not to exceed one thousand dollars.

Sec. 6. That any person, company, or corporation violating the provisions of sections two or four of this act shall be guilty of a misdemeanor, and on conviction shall be punished by a fine of not less than one hundred dollars nor more than one thousand dollars, or by imprisonment not more than one year or by both such fine and imprisonment.

Approved, March 3, 1905.

TWENTY-EIGHT HOUR RELEASE-INTERSTATE SHIPMENT.

United States Regulation.

No railroad, express company, car company, common carrier other than by water, or the receiver, trustee, or lessee of any of them, whose road forms any part of a line of road over which cattle, sheep, swine, or other animals shall be conveyed from one state or territory or the District of Columbia, or the owners or masters of steam, sailing, or other vessels carrying or transporting, cattle, sheep, swine, or other animals from one State or Territory or the District of Columbia into or through another State or Territory or the District of Columbia, shall confine the same in cars, boats, or vessels of any description for a period longer than twenty-eight consecutive hours without unload- 
ing the same in a humane manner, into properly equipped pens for rest, water, and feeding, for a period of at least five consecutive hours, unless prevented by storm or by other accidental or unavoidable causes which cannot be anticipated or avoided by the exercise of due diligence and foresight: PROVIDED, That upon the written request of the owner or person in custody of that particular shipment, which written request shall be separate and apart from any printed bill of lading, or other railroad form, the time of confinement may be extended to thirty-six hours. In estimating such confinement, the time consumed in loading and unloading shall not be considered, but the time during which the animals have been confined without such rest or food or water on connecting roads shall be included, it being the intent of this act to prohibit contingencies hereinbefore stated: PROVIDED, 'That it shall not be required that sheep be unloaded in the night time, but where the time expires in the night time in case of sheep the same may continue in transit to a suitable place for unloading, subject to the aforesaid limitation of thirty-six hours.

That animals so unloaded shall be properly fed and watered during such rest either by the owner or persons having the custody theneof, or in case of his default in so doing, then by the railroad, express company, car company, common carrier other than by water, or the receiver, trustee, or lessee of any of them, or by the owner or masters of boats or vessels transporting the same, at the reasonable expense of the owner or person in custody thereof, and such railroad, express company, common carrier other than water, receiver, trustee, or lessee of any of them, owners or masters, shall in such case have a lien upon such animals for food, care, and custody furnished, collectible at their destination in the same manner as the transportation charges are collected, and shall not be liable for any detention of such animals, when such detention is of reasonable duration, to enable compliance with Section one (first paragraph hereof) of this act; but nothing in this section shall be construed to prevent the owner or shipper of animals from furnishing food therefor, if he so desires.

That any railroad, express company, common carrier other than by water, or the receivers, trustee, or lessee or any of them, or the master or owner of any steam, sailing, or other vessel who knowingly and wilfully fails to comply with the provisions of the two preceding sections (paragraphs) shall for every such failure be liable for a forfeit and pay a penalty of not less than one hundred nor more than five hundred dollars: PROVIDED, That when animals are carried in cars, boats, or other vessels in which they can and do have proper food, water, space, and opportunity to rest the provisions in regard to their being unloaded shall not apply.

That the penalty created by the preceding section (paragraph) shall be recovered by civil action in the name of the United States in the Circuit or District Court holden within the district where the violation may have been committed or the persons or corporation resides or carries on business; and it shall be the duty of United States Attorneys to prosecute all violations of this Act reported by the Secretary of Agriculture, or which may come of their knowledge by other means. .

The rules and regulations of the various railroads are for all practical purposes the same-this being obvious when attention is called to the fact that all the participating carriers of any given road are bound by the rules and regulations of the originating carrier. Hence, it is deemed inadvisable to give verbatim the rules and regulations of each individual road, as to do so would only be a repetition and would tend to confuse and work no practical end.

A familiarity with the following rules and regulations will place the shipper in a familiar status with the rules and regulations of all the railroads. 


\section{RAILROAD RULES AND REGULA- TIONS}

COW PONIES, CARLOADS C Cattle rates will apply on Cow Ponies in mixed carloads of Cattle and Cow Ponies or straight carloads of Cow Ponies.

Applies only between points in Nebraska.

CALVES IN DOUBLE DECK CARS-Calves in double deck cars will not be accepted for shipment.

GOATS, CARLOAISS-Goats, carloads, apply sheep carload rates and minimum weights.

HOGS IN DOUBLE DECK CARS, CARLOADS-Rate on Hogs in double deck cars will be 200 per cent of the charge on a single deck the same size.

SHEEP IN DOUBLE DECK CARS-Under the law of the State of Missouri, Section 1992, R. S. No. 1899, Railroad Companies are required to provide double deck cars for carrying Sheep, and to carry such double deck cars at the same rate as for one car Cattle.

Railroad Companies not having a sufficient or proper equipment of cars to accomodate this, are permitted to use single deck cars, but no more can be charged for two single deck cars loaded with sheep than is charged for one carload of Cattle.

Applies only between stations in Missouri.

SHEEP IN TIERED CARS-The rates provided on Sheep in double deck cars will apply on Sheep in Tiered Cars.

ACCEPTING DIPPED SHEEP-Shipments of Sheep which have been dipped will not be accepted for shipment until same have been out of the dip at leasi 24 hours.

ORDERING CARS-On account of the charges on shipments rated in dollars per car and the minimum weights on shipments rated in cents per 100 pounds being based on the length of car used, shippers must be particular to state in their order to Agents the length of car desired.

FURNISHING CARS OF DIFFERENT SIZE THAN ORDERED-When carrier can not furnish car of length or capacity ordered by shipper, and for its own convenience furnishes car of greater capacity than the one ordered by shipper, it will be used on the basis of the minimum carload weight named herein to apply on size of car ordered by shipper, but in no case less than actual weight.

The capacity of the car ordered, the number of the order and the date of same, initials, number and capacity of cars furnished to be shown in each instance on the bill of laring and waybill.

In no case must shipment be billed at minimum weight prescribed for a car of less capacity than in general service.

App'ies only when shipment tendered could have been loaded into car of the size or carrying capacity or lered by shipper.

Under above rules orders will not be accepted for cars of less capacity than prescribed by minimum weights named herein.

St. Joseph \& Grand Island Ry. has no stock cars of liss length than 36 feet and 6 inches and will not undertake to supply smaller cars or protect minima applicable on cars of less dimensions.

TRANSPORTATION FOR CARETAKERS IN CHARGE OF LIVE STOCK-Live Stock Contracts when presented by men actually in charge of the stock, will be honored for transportation as indicated below and in accordance with Rules and Instructions herein given. 
(a) One man will be passed in charge of one car of live stock :No return pass will be given, except that return pass will be given: to men who accompany one carload of horses, mules or asses. (See note: below).

(b) One man will be passed each way when in charge of two.n to five cars of Live Stock from one owner on the same train.

(c) Two men will be passed each way when in charge of 6 to: 10 cars of Live Stock which is the maximum number of men that will be passed with six to ten cars of Live Stock for one owner on 2 . the same train.

(d) Three men will be passed each way when in charge of 11: or more cars of Live Stock which is the maximum number hat will be passed with Live Stock for one owner on the same train.

(e) When two cars of stock are shipped from different stations by same owner and are received at destination on same train. man in charge shall be entitled to return pass to station nearest to market.

(f) Women or persons under 18 years of age or persons incompetent to take charge of Live Stock will not be passed in charge of Live Stock.

(g) Return passes for men in charge of Horses and Mules to: be presented within sixty days, and for men in charge of other stock: within twenty days after date of contract, the return passage to $b \in$ : commenced within twenty-four hours after the issuance of returr. pass.

(h) Persons will use the original live stock contract for the going transportation, and upon surrender of such original contract within the time limit specified in this item, he will receive for return. journey stock ticket, or tickets if entitled thereto. Duplicate in alt cases to be retained for the Company's use, and must be forwarded: to the Auditor without delay.

(i) It is very important that the forwarding agent shall seethat the Live stock Contract (original and duplicate) is properly filled in and executed in ink, and that the parties in charge of or attending the live Stock and entitled to free transportation, sign their name in the space provided on the back of the contract under the heading "Release for man or men in charge." Agent should draw his pen through any such spaces as are not used, and stamp the contract in the space provided therefor.

(j) If party returning is entitled to free transportation, as provided in rules shown herein, and surrenders stock contract before its expiration issue a return stock ticket (Form L-15).

(k) The agent at destination to whom an original Live StockContract is presented with request for return transportation, must require the parties to sign their names on the back of the contract under the heading, "Receipt for the return transportation," etc: $\mathrm{He}$ must then inspect it carefully, compare the signatures with those under the heading, "Release for man or men in charge," and satisfy himself that they are identical before issuing stock tickets. In case the Live Stock attendants entitled to return transportation in connection with any single contract do not wish to return at the same time, the agent will take up the original contract when presented by the party desiring to return first, and will hold it until the others call for their return transportation; it being understood that the limit, 20 or 60 days, as authorized, shall not be exceeled. As soon. as all the return transportation has been issued the Agent will for-. ward the original Stock Contract to the Auditor, together with the report of the stock tickets issued thereon. Agents failing to compir. with this clause will be charged with the ticket at full tariff rates.

(1) Persons in charge of Live Stock will be carried only upor 
the same train in which Live Stock is forwarded. Return transportation will be good on passenger trains.

(m) Transportation will be furnished only to owners, shippers or men actually in their employ who have accompanied the shipments to destination. Agents will be careful to see that merchants or sraveling men who have no interest in the stock, and who would otherwise pay their fare, are not passed on account of stock shipments. Agents must see that this rule is observed.

(n) The above rules will apply on shipments from one consignor only.

(o) Agents must not issue more than one contract to any one shipper whose Live Stock moves same date and train.

(p) No return transportation will be furnished to persons in charge of Live Stock except as provided above.

(q) When two single deck cars are furnished in lieu of one double deck car, return transportation will only be furnished the same as if the party had accompanied the double deck car as originally ordered.

NOTE:-One man will be passed each way when in charge of one car of live stock moving between points in Missouri.

LIVE STOCK SHIPMENTS WITHOUT CARETAKERS-When owners or shippers desire to forward their Stock without a caretaker in charge and the railroad company accepts the shipment under these conditions, it must be understood that in so doing the shipper assumes all risk of loss or damage, and notation to that effect must be made on the Live Stock Contract and waybill, and the Agent must write in ink or istamp, in space provided for the signature of the caretaker on back of Live Stock Contract. "No attendant in charge; this contract is not good for return transportation."

This information must be telegraphed to junction points and points at which stock is billed to feed. Agents will be held personally responsible for the enforcement of this rule.

LIMITATION OF LIABILITY-Rates on Live Stock published Therein, will apply on shipments made at owner's risk, with limitations of liability on the part of the railroad company as common carrier under the terms and conditions of the current Live Stock Contract provided by this company as shown herein, the contract to be first duly executed in manner and form provided for therein.

Where the declared value exceeds the limited liability value as provided in our Live Stock Contract, an addition of twenty-five (25) per cent shall be made for each one hundred (100) per cent., or fractional part thereof for such increase. Where Live Stock Contract is not executed, and stock handled at carrier's risk, the rate shall be one hundred and fifty (150) per cent. of the limited liability rate as above. Shippers shall be required to declare the value of live stock offered, and shipments will not be accepted where this information is refused.

RECONSIGNING OF LIVE STOCK-Shippers who wish to avail themselves of the through rate to Kansas City, Mo., on Live Stock must execute contracts showing destination Kansas City, Mo., and way bills for the shipments must show the same destination. If shipments which are consigned through are sold at St. Joseph, Mo., they will be delivered at the St. Joseph, Mo., rate, but if forwarded to Kansas City, Mo., as shown on the contract and billing through rate will be protected. Shipments which are consigned to Kansas City, Mo., with privilege of trying St. Joseph, Mo., market will be billed to St. Joseph, Mo., at proper rate but if the shipper does not desire the privilege of St. Joseph, Mo., market, the shipment will be billed through to destination in accordance with instructions issued by the Auditor. 
NOTE: Carload shipments of Live Stock, consigned locally, torn St. Joseph, Mo., may be reconsigned to. Kansas City, Mo., at authorized through rates from points of origin to final destination only when the identity of the original carload has been preserved without addition, removal, or change in the original contents of the car ex : cept from death from natural or accidental causes or from injury in. transit of animals comprising the shipment, and without change in ownership of the shipment.

WEIGHING OF HORSES AND MULES, CARLOADSHorses and Mules will not be weighed but will be billed on: the basis of the minimum weights provided for the various sized cars as shown herein.

EXECUTING LIVE STOCK CONTRACTS-In executing Live Stock Contracts, either for car loads or single animals, the authorized rate upon which the shipment is moved must be inserted. in the space provided for the rate in the Live Stock Contract blank. Writing the word "Tariff," or abbreviations for that word, in the rate space must be discontinued entirely.

Parties actually in charge of live stock must be required to sign their names in their own handwriting, on back of Stock Contracts.

It is very important that the forwarding agent shall see that: Live Stock Contract (original and duplicate) is properly filled in ands executed in ink, and that the parties in charge of or attending the Live Stock and entitled to transportation free, sign their names in spaces provided on back of contract. Agent must be careful that the names of parties not actually in charge of shipment are not placed upon the contract and should draw his pen through any such spaces as are not used and stamp the contract in the place provided therefor.

Agents in executing Live Stock Contracts must fill in blank space provided therefor, the Live Stock valuations as provided therefor, the live stock valuations as provided in Western Classification or abbreviations for same, as reference for limited valuation will not do.

RENTAL CHARGE FOR USE OF ARMS PALACE HORSE CARS-These cars are to be used for transporatation of Horses only and rental charge will be made in addition to the regular freight rate as follows.

DESCRIPTION-Series 30 to 2500 (Crosswise Stalled) 20 horses-48 feet in length; 18 stalls; water tanks; feed mangers. Room: for one or two extra horses in doorway. Equipped for freight train service.

100 miles or less, continuous trip $\$ 10.00$.

101 miles to 300 miles, continuous trip $\$ 12.00$.

301 miles to 500 miles, continuous trip $\$ 15.00$. distance.

501 miles or over, continuous trip three cents per mile, loadec

(See exceptions below.)

DESCRIPTION-Serries 3000 to 3030 (Without iStalls) -28 Horses - 60 feet long; three compartment car; used in passenger service only.

Rental charges the same as for Series 5001 to 5021 .

DESCRIPTION_Series 4000 to 4250 (Without Stalls) - 22 to 26 Horses-48 feet in length; stalless car with three compartments = for loading animals loose. Equipped for freight train service.

200 miles or less, continuous trip $\$ 6.00$.

201 miles to 500 miles, continuous trip $\$ 10.00$.

501 miles to 700 miles, continuous trip $\$ 15.00$.

701 miles to 1,200 miles, continuous trip $\$ 18.00$.

1201 miles to 1,590 miles, continuous trip $\$ 20.00$.

For every 109 miles or fractional part thereof in excess of 1,56 miles $\$ 1.00$ additional (See exception below.) 
DESCRIPTION-Series 5001 to 5021 (Lengthwise Stalled). ComBoination Horse and Carriage Cars.-16 Horses-44 feet in length; 16 portable stalls; water tanks; feed boxes. These cars, except Nos. 5001 to 5003, inclusive have doors 8 feet wide, admitting vehicles on their wheels. Also specially suitable for shipping race horses. Equipped for passenger and freight train service.

100 miles or less, continuous trip $\$ 10.00$

101 miles to 400 miles continuous trip $\$ 16.00$ adistance.

401 miles or over continuous trip four cents per mile, loaded

DESCRIPTION-Series 6001 to 6350 (Lengthwise Stalled). Formerly known as Burton Perfected Cars.-16 Horses-44 feet in length; 16 adjustable stalis; water tank; feed trough. Especially designed for shipping race horses. Equipped for passenger and freight train service.

100 miles or less continuous trip $\$ 10.00$

101 miles to 400 miles continuous trip 16.00

401 miles or over continuous trip four cents per mile loaded disvance, with a cents per mile, loaded distance.

(a) Rental charge must be collected or billed as advanced charges at loading station for the entire trip, i. e. through to final destination.

(b) Where cars of the description ordered are not available, Arms Palace Horse Car Co. reserves the right, with shippers' consent, to substitute cars, taking a higher rate and charge the lower rate applicable to the kind of car ordered.

RENTAL CHARGE FOR USE OF KEYSTONE PALACE HORSE CARS-(Owned and operated by Arms Palace Horse Car Co.)

Cars, length inside, 48 feet; 18 diagonal stalls, with room in center aisle for one or two extra animals.

100 miles or less, continuous trip, $\$ 1.0 .00$.

101 to 300 miles continuous trip, $\$ 12.00$.

301 to 500 miles, continuous trip, $\$ 15.00$.

501 miles or over, continuous trip, three cents per mile loaded distance.

Rental charge is in addition to regular freight rate.

RENTAL CHARGE FOR USE OF DOUD PALACE HORSE CARS-On Doud cars, Series 500 to 599, inclusive, when loaded with thorses and mules, one cent per car per mile, minimum charge $\$ 5.00$ per car and which is in addition to the regular freight rate. When the above numbered cars are loaded with cattle, sheep, or hogs no rental charge will be made. On other Doud cars (not numbered as above) no rental charge will be made when loaded with any kind of dive stock.

RENTAL CHARGE FOR USE OF MATHER PALACE HORSE CARS-Mather Horse Cars Nos. 7501 to 1908 (inclusive) are especially designed for horses.

Rental charge is made for the use of these cars, when loaded with Horses, Mules or Fine Stock, of one cent per mile the loaded way, with a minimum charge of five dollars $(\$ 5.00)$ for any one trip and which is in addition to the regular freight rate.

RENTAL CHARGE FOR USE OF STREETS PALACE HORSE CARS-No rental charge will be made for the use of cars belonging to the Street's Western Stable-Car Line, which are known and lettered "Street's Western Stable Car Line," "Hicks Stock Car," .C. C. C. C." (Consolidated Cattle Car Co.) and "Quaker City Live Stock Line," when loaded with Cattle, Horses and Mules.

STOPPING IN TRANSIT OF HORSES. MULES OR ASSES TO FINISH LOADING-Horses, Mules or Asses in carload shipments may be stopped once in transit to finish loading at a charge of $\$ 5.00$ per car therefor. Such stop to be limited to twenty-four 
hours, and Horses, Mules or Asses will not be allowed to be taken from the yards.

STOPPING IN TRANSIT OF HORSES MULES OR ASSES FOR FEED, REST OR SALE-Shipments of Horses, Mules or Asses may be stopped in transit at points intermediate between point of origin and destination for feed, water and rest. Such stops not to exceed a period of 72 hours. No change in the identity of the Live Stock constituting the original shipment will be allowed. No charge will be made for stops made for" this purpose.

Shipments of Horses, Mules or Asses may be stopped in transit at points intermediate between point of origin and final destination for the purpose of sale or speculation at a charge of $\$ 10.00$ per car for each stop. Each stop shall be limited to 15 days and such stops will be restricted to points west of the Missouri River.

Instructions for stopping in transit for sale or speculation shall be noted on the original Live Stock Contract and on the way-bill, and stops for such purposes shall not otherwise be made save on the original order of the consignee.

The Agents will note on billing a record of each stop and the duration of same.

If there is an exchange of Horses, Mules or Asses, or an addition of local Horses, Mules or Asses during the stop the waybills will be taken into account at the local rate to the stopping point.

STOPPING IN TRANSIT OF CATTLE, HOGS OR SHEEP FOR FEED, REST OR SALE-Shipments of Cattle, Sheep or Hogs may be held in Stock Yards for feed, rest or sale as follows: Cattle or Hogs, ten days; Sheep, thirty days.

STOPPING IN TRANSIT OF RANGE HORSES TO PUT IN CONDITION FOR MARKETING-Range Horses may be stopped in transit for a peicod not exceeding one year to put in condition for marketing at the following charges:

Cars 31 feet and under in length, inside measurement.

Cars over 31 feet to and including 33 feet 6 inches, in length,

inside measurement

Cars 33 feet 6 inches to and including 36 feet in length, inside measurement 16.00

STOPPING IN TRANSIT OF CATTLE AND SHEEP FOR FATTENING-Cattle or Sheep in double deck cars, straight carloads, originating at points on the St. Joseph \& Grand Island Railway in Kansas or Nebraska, destined to St. Joseph or Kansas City, Mo., may be stopped to fatten in transit at intermediate stations on the St. Joseph \& Grand Island Railway in Kansas or Nebraska, under the following conditions:

(a) Agents at original point of shipment must make notation on each waybill "To fatten in transit," and must be particular to note on each waybill the number of head of cattle or sheep loaded in each car.

(b) The charge for this privilege will be 7 cents per 100 pounds above through rates from point of origin to destination, based on the minimum weights shown herein, naming rates to St. Joseph or Kansas City, Mo.

(c) Charges based on these rates and minimum weights must be collected at the stopping point.

(d) Shipments must be re-shipped from stopping point within twelve months (one year) from date of shipment from point of origin.

(e) All live stock stopped in transit under these terms will be weighed at final marketing points, and all surplus weight caused by fattening will be charged for at local rate stopping poinc to market. 
(f) It should be understood that the total charge (not including privilege charge) should not be in excees of the amount chargeable on the greater length of car point of origin to final destination, subject to final destination weight, when through rate is in cents per 100 pounds.

(g) In waybilling from stopping points, agents must give full reference to the waybill on which shipment was received, showing the initial, number and size of car in which received, the weight at which shipment was taken into account, and the amount collected at stopping point.

ALLOWANCE FOR FILL-On carload shipments of Cattle and Hogs forwarded from Kansas City, Mo., or St. Joseph, Mo., the following deductions will be made from weights obtained at points of shipment after the Cattle or Hogs have been fed and watered, subject to minimum carload weight prescribed in the Tariffs:

Cattle 500 pounds per car

Hogs, in single deck cars 300 pounds per car

Hogs, in double deck cars 600 pounds per car

LIVE STOCK RATED IN DOLLARS PER CAR-Where the rates in this tariff on Live Stock are named in dollars per standard car, such rates are to be used only as a basis for obtaining rates as follows and will apply on cars either common or patent.

Cars 33 feet 11 inches or under, $107 \%$ of the Standard Car Rates. Over 33 feet 11 inches, to and including $36 \mathrm{ft}$. 7 inches,

Over 36 feet 7 inches, to and including $38 \mathrm{ft}$.,

$110 \%$ of the Standard Car Rates.

Over 38 feet, to and including 40 feet,

$113 \%$ of the Standard Car Rates.

Over 40 feet, to and including ing 42 feet,

$116 \%$ of the Standard Car Rates.

$125 \%$ of the Standard Car Rates.

Over 42 feet, to and including 44 feet,

$135 \%$ of the Standard Car Rates.

Over 44 feet, $140 \%$ of the Standard Car Rates.

\section{MINIMUM WEIGHTS ON LIVE STOCK RATED IN CENTS} PER 100 POUNDS.

LENGTH OF CARS-lnside Measurement.

MINIMUM WEIGHTS-In Pounds.

Cattle. S. D.

Sheep, D. D. Hogs. S. D. Sheep, S. D

Cars 33 feet 11 inches or under....

20,500

16,000

11,000

Over 33 feet 11 inches, to and including 36 feet 7 inches in

length

22,000

17,000

12,000

Over 36 feet 7 inches, to and including 40 feet in length

24,000

19,000

14,000

Over 40 feet in length

$26,000 \quad 21,000$

16,000

SPECIAL OR PALACE CARS-Live Stock loaded in Special Live Stock or "Palace" cars (not the property of railroad companies) will be subject in all cases to full carload minimum for each car used, and in no case will less than carload rates and minimum weights apply.

The usual charge for rental to be assessed in addition to the regular transportation charges.

WEIGHTS ON LIVE STOCK AT KANSAS CITY, MO.There being no general arrangements at Kansas City, Missouri, with Stock Yards Company or commission firms to obtain hoof selling 
weights on all Live stock consigned to that market, making it necessary to track scale cars loaded and light, it is understood, when requests are made to set aside such track scale weight in favor of hoof selling weights, that such hoof weights less usual fill allowances may be protected when same are greater or less than the net track scale weight by more than 1,000 pounds, subject to established minimum weights, When such hoof selling weights, less the usual fill allowance, do not vary more than 1,000 pounds from the track scale weights, no correction will be made and track scale weights, subject to established minimum weight will be the basis for freight charges.

When cars are not track scaled the hoof selling weight less the usual allowances for fill will be the basis for freight charges subject to the established minimum weights.

STOCK CATTLE, STOCK HOGS AND STOCK SHEEP, DOUBLE DECK, WESTBOUND-Stock Cattle or Stock Hogs in single deck cars, and Stock Sheep in double deck cars, westbound, seventy-five per cent. of the eastbound rate will apply except to stations as shown below on Stock Cattle.

Stock Cattle will take 75 per cent. of the Fat Cattle rate from Kansas City, Mo., and St. Joseph, Mo., to stations Avondale, Mo., to Gower, Mo., inclusive, subject to the following minimum weights and charges:

\section{LENGTH OF CAR.}

Inside Measurement.

In cars 34 feet and under.

In cars 34 feet 6 inches and under........................

In cars 35 feet and under....

In cars 35 feet 6 inches and under...............

In cars 36 . feet and under.

In cars over 36 feet.
Mnimum Minimum

Weight. Charges.

$20,700 \quad \$ 11.00$

$21,100 \quad 11.00$

$21,500 \quad 11.00$

$21,800 \quad 11.00$

$22,000 \quad 11.00$

$22,000 \quad 11.50$

Exception: Will not apply on shipments of Stock Cattle, carloads, between Kansas City, Mo., and St. Joseph, Md. Between these points apply Fat Cattle rates.

FEED IN STOCK CARS-Feed, except loose hay in racks, will not be permitted to be loaded with carloads of Live Stock.

BEDDING-Bedding for cars to be loaded with Live Stock will be furnished and placed in the cars without charge. When furnished by the shipper at his own expense, an allowance of twenty-five (25) cents per car, either single or double deck, will be made from the freight charges, waybills to bear notation in each case certified to by forwarding agent. "Twenty-five (25) cents deducted from freight charges account bedding furnished by shipper."

Exception: No allowances will be made for bedding furnished by the shipper at feeding points for the Live Stock moving under feeding in transit rates.

MIXED CARLOADS-Mixed shipments of Live Stock may be received for transportation when not in conflict with State Laws, subject to the following rules:

Each class of stock to be separated by a good and sufficient partition at owners' expense, which shall be fastened to the car without the use of nails or spikes, or any other fastening which will injure or deface the car.

Where rates are in dollars per car, the rate on mixed carload shipments of Live Stock so received is to be the highest rate for any grade of stock in the car, and subject to authorized percentages for cars of different length.

On shipments of Live Stock rated in dollars per car, when loaded in Palace cars, having permanent stalls, the rate on highest class will govern. 
Telephone 858

Dr. Alfred N. Hagan DENTIST

Office and Residence

24th and M. Sts.

Opposite Post-Office

South Omaha, Nebraska

\section{Central Taxicab and Auto Livery Company}

Stand:

1415 Farnam Street

\section{Phone Douglas 862}

We Solicit Stockmen's Trade

Patents Developed. Models and Experimental Work.

\section{American Machine Works}

WARREN STIBOLT, Prop.

Repairing of All Kinds of Machinery. Tools, Dies.

Special Machinery Built to Order

110 South 11th Street Phone Doug. 4881, Omaha

Office Telephone, South 2140

Dr. M. H. Anderson DENTIST

Over Live Stock

National Bank

South Omaha, Nebraska

\section{POUNDS BAR}

\section{No. 26th Street}

South Omaha, Nebraska

Restaurant ... In ...

Connection

POPULAR PRICES

Celebrated Schlitz Beer on Tap

Also Agents for RED TOP RYE

S. M. Sadler C. C. Sadler Telephone Doug. 1326

\section{S. M. Sadler \& Son} ABSTRACTS OF TITLE

Titles Examined and Perfected Irrigation Titles a Specialty

216-218 State Bank Bldg. OMAHA, - $\quad$ - NEB.

Phone Harney 3669 Stand Doug. 150.

\section{Shively's Auto Livery}

7 Passenger Cars

Ready Day or Night OMAHA 
*In no case shall the charge for a car of mixed Live Stock be less than would be charged for a car of same length loaded with Cattle.

\begin{tabular}{|c|c|c|}
\hline KIND OF LIVE $\mathrm{S}^{\prime}$ & & MINIMUM W] \\
\hline Cattle and Hogs & $\mathrm{Hog}$ & Hogs \\
\hline Cattle and Sheep & Sheep & . Sheep \\
\hline Cattle, Hogs and & Sheep & \\
\hline Hogs and Sheep in single & She & \\
\hline Hog's and Sheep in dou & Hog & Hog (See No \\
\hline $\begin{array}{l}\text { Hogs and Sheep } \\
\text { each deck of }\end{array}$ & Hog & $\begin{array}{l}\text { cent of the sin- } \\
\text { k Hog minimum }\end{array}$ \\
\hline $\begin{array}{l}\text { Cattle, Hos } \\
\text { Horses }\end{array}$ & $\begin{array}{l}\text { Horse for } \\
\text { size of } \\
\text { car used. }\end{array}$ & $\begin{array}{l}\text { pounds; any ex- } \\
\text { over } 20,000 \text { lbs. to } \\
\text { arged for at a pro- } \\
\text { onate rate. }\end{array}$ \\
\hline
\end{tabular}

NOTE: When a full deck of Sheep and a full deck of Hogs are loaded in a double deck car the single deck rate and minimum weight on each will apply.

*Will not apply on Nebraska State Traffic per Opinion and Order of the Nebraska State Railway Commission in formal complaint No. 139, April 11, 1912.

STOPPING IN TRANSIT OF CATTLE, HOGS OR SHEEP FOR FEED, REST OR SALE-Shipments of Cattle, Sheep or Hogs may be held in Stock Yards for feed, rest or sale as follows: Cattle or Hogs, ten days; Sheep, thirty days. 


\section{UNIQUE AUTO LIVERY}

JOE SUTLEY, Prop.

\section{First Class TaxiCabs \& Touring Cars}

Phone Tyler 1-8-2

5 Passenger Cars

\$2.00 Per Hour

7 Passenger Cars \$3.00 Per Hour

\section{WHY PAY MORE?}

Competent Drivers,

Service Day and Night

Office and Garage 2024 Douglas Street

\section{STOCKMEN}

\section{MUST EAT}

WHEN they want, WHAT they want; WHERE they want,

But they always want to eat it at the

\section{Hub Dairy Lunch}

Sioux City, lowa
ATTENTION IS CALLED

to the enclosed letter of

The Mid-West Bank

"That always treats you right."

SIOUX CITY, IOWA.

They have banked with farmers and stockmen since 1886, know and like' them and desire to become headquarters for every farmer in Iowa, Nebraska and South Dakota. Write them or call for anything wanted.

Party, Theatre. Wedding and Dance Calls a specialty. Train and emergency calls solicited. Reasonable Rates, Careful Drivers. Phones: Auto,, 4541. Bell, 416. MOTOR MART

\section{AUTOMOBILE LIVERY AND CAB SERVICE}

The Auto Business in all It's Branches

DAY AND NIGHT SERVICE

THE BENHETT AUTO SUPPLY CO.

R. A. BENNETT, Pres. and Gen. Mgr. E. L. BARTHOLOME W, Livery Mgr. 6th and Nebraska Sis. SIOUX CITY, IOWA 


\section{INDEX}

\section{INDEX TO NEBFIASKA LAWS.}

\section{Polnts Covered by Articles.}

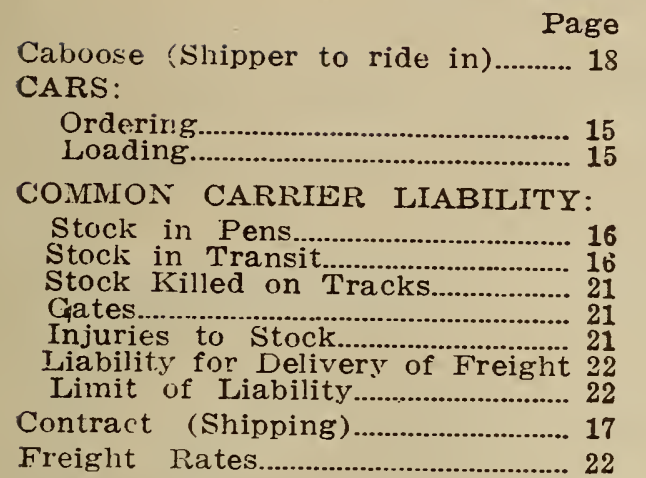

Page

Imported Stock..................................... 20

Side Track-Private............................. 16

Speed of Live Stock Shipments... 12

Stock Not to be in Cars Over 36 Hours................................................... 19

Stock Yards, (Destinàtion) Laws Governing....................................... 19

Thirty-six Hours Release................ 19

'Iransportation for Stockmen.......... 18

YARDS:

Railroad................................................. 15

Private....................................................... 15

Establishing........................................... 15

\section{STATUTE LAWS.}

Page

BRANDS:

Altering Brand or Ear-Mark...... 51

Butcher to Record Marks and Brands, Exhibit Hides, and Keep for Three Davs.

Filed With Secretary of State...

Herd Brought in for Grazing (Distinguishing Brands)............ 4

Hides, Keep Record of Brands, Penalty:

Must Not be Duplicated................. 48

Prim=-Lacie Evidence of Owner-

Offered for Record

ship, (Penalty for Violation) .. 50

fiecord, How Kept............................ 45

Recovered After Five Years......... 48

Rejected............................................ 49

Rights of Owners Not Impaired 50

'I'wo Similar, Last One Illegal.... 49

CRIMINAL LAWS (ANIMALS):

Abandoning Sick or Disabled An imals............................................. 59

Abusing or Overworking Animals................................................... 58

Shelter

Arrest of I'ersons for Cruelty to 58

Breaking Open or Injuring Pound ........................................... 59

Bull-baiting and Torture of Animals.

Cruel Treatment or Exposure of Domestic Animals

Cruelty to Animals..

False Stock Pedigree

Hog Stealing...

Horse Racing ...................................... 59

Horse Stealing, Buying or Con-

Killing of Injuring Animals............. 57

Mutilation of Horses........................ 57

Poisoning Anima!s With Intent to Injure or Destroy................... 59

stealing and Receiving stolen Cattle

Taking Horse or Mule Without Leave...

Dogs-Damage by Dogs, Persons Toint'y and Severaly Liable, Right to Kill Dogs

RISEASED CATTLE.

Diseased Animals Not to Come in Contact With Others.............. 4 Penalties..................................................... 46 Hog Cholera............................................. 46

Carcasses Not Sold.......................... 46

Tustice of the Peace May Impound Diseased Cattle, etc........ 46

Selling or Allowing Diseased Animals to Kun at Large..

46

ESTRAYS AND STOCK RUNNING A'T LARGE:

Appraisers' Fees................................. 36

Arbitration in Case of Disagreement................................................ 35 Arbitrators to Assess Damages Caused by Estrays......................... 33

Award of Arbitrators......................... 33

Description and Publication of Stock Taken Up..............................

Damages, How Assessed................ 34

Danages, Notice to Owner ofForm of Notice............................... 32

Damage on Enclosed Iand.......... 34

Damares to Cultivated Land........ 32

Failure of Owner to Pay Damages..

Selling of Male by Taker-up 36

Keeping of Live Stock, Allow-

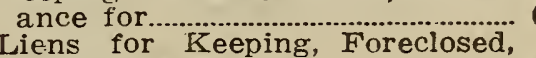
Affidavits Fil ed................................ 63

Limitation of Law.......................... 34 Liability of Person Growing Crop on Uninclosed Land.......... 34

Lien, Subject to, for Damage.... 33

Lands, Cultivated, Defined............ 33

Liens on Live Stock-Miscellaneous ....................................... 63

Must Bring Two-thirds of Appraised Value................................. 36

Owner May Reclaim Before Sa:e 35

Penalty for Violation of................. 36

Place of Sale......................................... 36

Proceeds of Sale................................... 36

Published Five Weeks for Three Dollars.

Remedy in Court Action............... 35

Sheep and Swine Not'to Run at Large........................................... 33 Stock Not to Rur at Large at Night.............................................. 33 Taker-up Not Liable for Loss Cattle Not to Run at Large.................................................... 40 by Death....................................... 37 


\section{STOCK YARDS SADDLERY CO.}

J. G. BLessing, Proprietor

WHOLESALE AND RETAIL

HAND MADE HARNESS AND SADDLES

FLY NETS, LAP ROBES AND FLY COVERS

No establishment on earth carries a

better variety of horse furnishing goods

Cheapest on Earth,

Quality Considered.

314 North 25th Street South Omaha, Neb.

\section{Howard R. Cronk}

\section{OPTOMETRIST and OPTICIAH}

1611 Farnam St.

ОМАНА

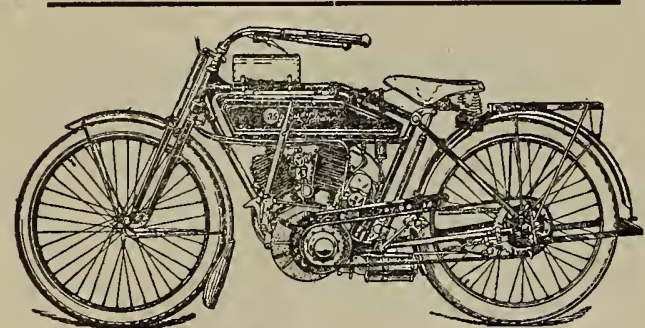

R. S. Motorcycle Co.

W. E. DEWEY, Mgr.

Write for free catalogue, agents wanted 1624 Cap. Ave.

Omaha, Neb.

408 E. 15th St.

Kansas City, Mo.

Phone: Red 5788

European - Plan.

All Outside Rooms.

\section{New Grand Hotel}

Modern in Every Respect,

Steam Heat Baths, Hot \& cold water, electric light.

Moderate Prices.

Special rates by Week or Month

H. SCHOENWALD, Mgr. 520-24 So. 13th Street.

N. W. Cor. 13th and Jackson.

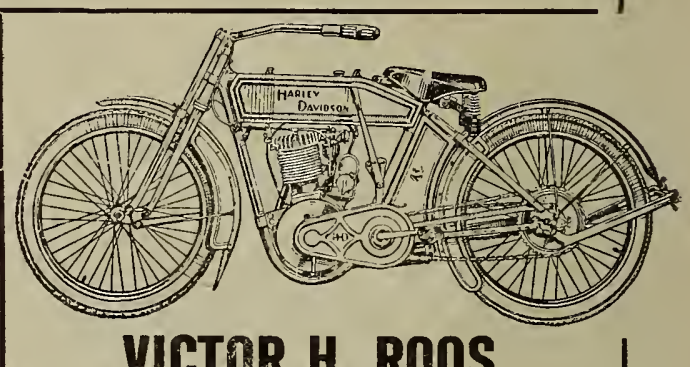

VICTOR H. ROOS

The Motorcycle Man HARLEY-DAVIDSON AND YALE MOTORCYCLES Bicycles, accessories and all kinds of repairing 2703 Leavenworth St. Omaha.

\section{Stockmen's}

Claim Association

We Respectfully

Solicit Your Business

Bee Bldg. Omaha, Neb.

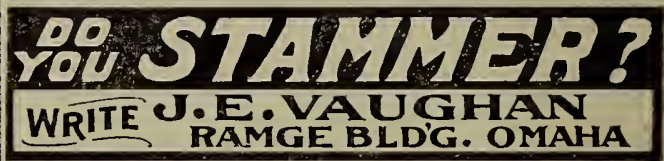




\section{INDEX - Continued}

Page

Taker-up Pays Fees and Charg-

Tender, Effect of by Owner........ 34 Value of Trouble and Expense by Appraisers Estimated............ 36

When Stock to be Taken $\tau$ p as Estray......................................... 33

When I'alrer-up Becomes Owner Without Sale. 36

When Estrays Become Property of Taker-up...................................... 35

\section{TENCE:}

Casual Destruction of Fence.

Injuring Fences, Gates, etc. 61

Lawful Fence. 62

Live Fences......................................... 60

Partition and Division Fences..... 60

Rairioad Fences, Notice to Ferice...

Removal of 62

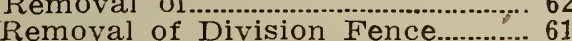

HERDING:

Damages for Driving off Cattle of Anuther

Driving off Cattle oi Another. (Fenalty ,............................................ 30

Drovel Cattle, Who Deemed...... 2:

Drover, Iuty to Protect Settler Fron! Stock...................................... 30

Ownership of Cattle, Evidence of

Penalty for Allowing Male Animal to Run at Large.................. 30 1)amages.

Penalty for failure to separate Cattie.

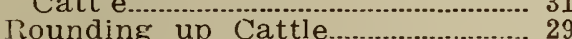

Stock Grower, who Deemed......... 29

INSPECTION OF ANIMALS:

Disease, Spread of, How to Prevent Among Sheep........................ 45 Diseased Sheep, Bringing Into State

Brought From Another State.... 43 Inspected Flocks, Powers and Duties with.........................................

Inspected Flocks, Powers and Duties on Inspection of.............. 44 Inspector, Fees of............................ 44

How Kept... 44

On Complaint...................................... 43

Questions Asked by Inspector..... 43

Record of Inspection.......................... 43

When Made. 43

IIVI STUCK SANITARY BOND:

Animals Examined and Appraised.

Duties of Deputy................................39

Duty of Public................................ 39

Duties, Powers...................................... 38

Emergency Cases................................. 39

Employes. 38

Offices, Ru'es, Compositions, etc 3\%

Right of Examination-Arrests.. 39

Veterinarian......................... 38

Name of Ranch or Home, Regis-

tering of................................................ 64

FITFALIS AND OLD WELLS:

Must be Filled.................................. 37

Notice Given to Owner..................... 37

Penalty for Violation.......................... 37

Road Overseer to See Same are

Filled.
(IUARANTINF AND Page IAAWS (PENALTIES FOR NONOBSERVANCE):

Act Does Not Prevent Damage Suit....................................................

Allowing Diseased Animals to Run.....................................................

Allowing to Run, or Selling of Diseased Animals........................ 40

Diseased Stock, Owner Must Burn........................ 41

How Finforced............................. 41

Bringing Diseased Animals Into State....

Harboring or Bringing Into

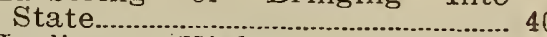

Hauling on Highway Hrohibited. 42

Manufacturers Forbidden to use Carcass of Diseased Hog............ 42

Using or Allowing Glandered Horses to Run................................ 40

HOG CHOLERA SERUM:

Hog Cho'era Serum Plant.

Pathology Animal, Department of. Appropriations for...................

Receipts from Sale of Serum........ 47

Serum. Nanufacture of.................. 4 ?

Sheep Inspector................................. 42

How Appointed.................................. 48

Who Fligible.......................................... 4 \&

Term of Ofice...................................... 42

Vacancy, How Filled..................... 42

SHIPPING LAWS:

Brand Inspection not Requirad in Open Market.......................

Caboose, Juty to Furnish............ 23

Cars for Shipping to ke Cleaned 26

Injuries to Animals.......................... 28

1NSPECIOR OF STOCK:

Abolition of Office. 27

Bond and Oath

Duties of .............................................. 27

Inspector, Shipping Fees of.......... 27

Liability foi' Freight.................... 28

liability for Stoch Injured.......... 2\&

liability for Violation Shipping Laws

Open Market........................................... 28

Penalties for Vio'ation of Shipping Act.........................................

Pens, Hearing of Petition to Secure..

Pens, Private, How to Secure...

Pens, Private Shipping.

Petition for Inspector of Stock.... 2

Shipments, Speed of Live Stock.

Sllipper, Duty of..

Yards and Pens (Shipping)...........

Penalties for not Providing.......... 24.

STALLIONS:

Advertisements. 55

Record of Certificate........................ 55

Certificate, 'Transfer........................ 55

A nimals-Removal of Same.......... 52

Certificate of Registration, How to Obtain.

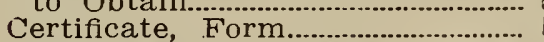

Certificates Heretofore Issued, Repeals, Forms............................. 56.

Duration of Lien for Service..... 5I

Fees..................................................... 55

Foreclosure of Lien......................... 52 :

Funds. How Used............................ 55 


\section{Buy direct from the manufacturer and save middleman's profit \\ Omaha Pillow Company \\ Manufacturers of \\ High-Grade Mattresses

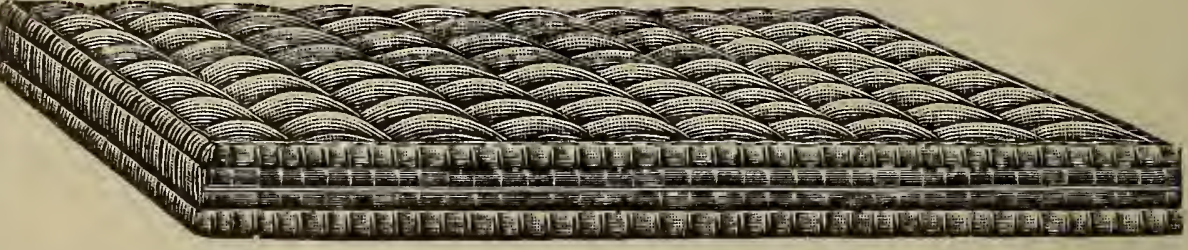

Pillows, Matiresses and Box Springs made to order Importers and Dealers in

FEATHERS AND DOWN OF ALL GRADES

Have Your Old Feather Beds Made Up Into

Summer and Winter Side Mattresses

Telephone and Mail Orders Will Receive Prompt Attention Telephone Doug. 2467. 1721 Cuming St., Omaha

\section{Lands and Investments} EVERYBODY WANTS TO BE RICH

\section{To get Rich is to be Influential To Get Rich You Must Save and Invest}

One good investment is often worth a lifetime's labor. I make a specialty of selling and exchanging lands and ranches. I have one investment whereby I guarantee $25 \%$ income each year, and do not ask for one cent until you have investigated, and satisfied it is as represented. I have a large list of improved farms and ranches to select from. Some ranches with a nice bunch of cattle, have two ranches with 500 acres of alfalfa on each one, that are bargains. Write

\section{A. C. JEWELL, "The Land Man"}




\section{INDEX-Continued}

Lien for Service 51 List of Animals Served.................. 51 Qualifications, Certificate Posted 55 Registrations of Stallions and

$\begin{array}{lll}\text { Violations of Act, Penalties.......... } & 56\end{array}$ STOCK YARDS:

Definition of Terms

Record of S.tock Hauled. 62

Scales and Yards, Furnish............. 63
State Railway, Commission, Control....................................................... 63

Unload in Tro Hours, Penalty.... 63

Taxes: .................................................. 64

Stock in Charge of Agent............ 64

Transportation, Cruel or Inhuman, of Animals,.......................... 64

Veterinarian (State) (See Live Stock. Sanitary Board.)

\section{INDEX TO IOWA LAWS.}

\section{Page}

Association for Promotion of Live Stock Industry 90

Commission of Animal Health. 89 CRIMINAL-ANIMALS:

Diseased Horses, Mules, etc., Bringing in................................... Allowing Diseased Horses, Mules, etc., to Run at Large.... 77

Swine Dying From Disease.......... 77 Must not Sell Animal Dying of Disease......................................

Cannot Convey Along Highway Carcass of Diseased Hog............ 77

Diseased Hogs-Permitting to Escape.................................. 77

Bringing Diseased Cattle Into State..................................... 77 Damaged Caused by Bringing Diseased Stock in State.............. 73 Crue!ty to Animals........................... 76

Railway3, When Trar.sporting...... 76 Damage to Fence, Produce or Fixtures.

Injuries to Beasts........................... 75

Impcrting Animals Without Food and Water.

Disturbing Stock.

Driving Away Stock...................... 76

Kacing or Fast Driving on Highways..

Jairy and Beef Cattle Industry... 92

Diseased Animals Killed................... 75

Ijogs (Sheep Killing Dogs)............. 75

ES'TRAYS:

Abandoned Aninials.

Hond to Release.....

Fees and Expenses.

Food and $W^{T}$ ater supplied............... 75

Marks and Brands........................ 71

Marks Previously Recorded......... 75

Notice Posted................................... 73

Penalty Against Finder.................. 71

Penalty Against Officer................... 74

Property Vests, When..................... 73

Pub!ication............................................ 73

Record.

Recovery by Owner..

Taking up Estrays

Tise or Appropriation....................... 74

Value Recorded.................................. 74

\section{FENCES :}

Appeal From Decision of Fence Viewers

Assignments of Portions.......... 87 Cattle Fuards-Crossings-Signs 87 Cattle Ways Across Highways... 87 Application for Cattle Way......... 87 Cross-fences.
Page:

Default - Damages - How Collected................................................. 8

Division Recorded 85

Failure to Fence, Liability for Stock Killed-Speed at Depots 88

Fence on Another's Land............. 85.

Fences Recuired on Railroad Right-of -way................................... 88

How Far Binding.................................. 85

Killing of Stock, Resulting From not Fencing Tracks.................... 88

T,ands in Different Townships... 85.

Lawiul Fence Defined..................... 86

Line Fences. 86

On One Side of Line......................... 86

Orders-Notice........................................... 8... 85:

Partition Fences................................... \$4:

Powers of Fence Viewers............. 84

Private Crossings............................. 87

Record Kept-Fees of Clerk........ 87

Repairs to Cattle Ways................... 87

Service of Notice

Where Stock Restrained................. 82

\section{HOG CHOIERA-(ERADICATION:} OF.)

Diseased Animals DestroyedCompensation................................... 8

Expenses of Quarantine, Condemnation and Distribution...... 81

Federal Inspection........................... 81

Penalty for Violation of Quarantine ................................... 81

Regulations............................................. 81

IJOG CHOLERA SEIRUM:

Appropriation

Disposition of Money Peceived.. 82

How Sold............................................ 81

Inspection for Future $\ldots \ldots \ldots \ldots \ldots . . . . . .8 \%$

Labnratory Supervision, etc......... 81

Penalty for Violation........................ 88

Present Laboratory Discontinued 83

Seizure-lixamination...................... $\$ 3$

Standard of Potency- Permit to Sell, etc.................................. 82

Use Limited to Certain Serum.. 8 ,

virus, How Sold, by Whom, Violation, Punishment.

JACKS:

Regristration (See Stallions.)

Liens of Livery Stable Keepers, etc...

Pedigrees (See "Stallion.")

REGIS'TERED PEDIGREED STOCK:

Registration (See "Stallions.")

STUCK LUNNTNG AT LARGE:

Apportionment of Damages 71 


\section{Don't Get}

\section{Discouraged}

When your young Pigs begin to show signs of loss of appetite and their ears droop and tail hangs straight down, that's their way of "WARNING" you that something is wrong and needs help.

OUR CRE-O-LONE HOG CHOLERA PREVENTIVE, will give the required aid. Tones the entire system. The Liver vibrates with new life. The Blood is cleansed of all impurities and carries renewed health to every vein and nerve and muscle and removes the constipation, then their trouble is gone. No more attacks until Improper feeding brings it on again. The discouraging features are gone and it seems worth while.

"DON'T FORGET" that it is "CRE-O-LONE" that you want.

\section{Cre-o-lone}

\section{Stock Tonic Co. 509 Pearl Street}

\section{Sioux City, - - - Iowa}




\section{INDEX-Continued ,}

Page

Assessment, How to Make Appeal.................................................. 72 Assessment of Damages, Sale...... 72 Distraint Damage Feasant-recovery....................................... 71

Escape or Re ease-Recapture.... 72 Ma:e Animals liunning at Large 71 Meaning of 1 erms.

Punishment for Uplawful Pelease 7

Recovery of Damages..................... 71

Restraining Live Stock--Submission to Joters

What Animals not Permitted to

Run at Large.................................... 71

STALLIONS:

Blind Stallion or Jack

Certificate of Soundness Certificate to be Posted and Contained in Advertisements.... 66

Disquaifications

Enforcement of Lien, Procedure 70

Enrollment-A nnual Certíica-

tion of Soundness......................... 65

importation Prohibited Unless

Accompanied by Veterinarian's

Certificate-Violation Punished 67

Imported Stallions or Jacks.......... 66

lien Upon Progeny........................... 70

Lien May be Contested.................... 70

Limitation of Lien.............................. 70
Page

Oath of Owner or Keeper or Certificate of Veterinariall....... 6.5 Transfer of Certificate-Fee........66 66 Permanent Stock Certificate of Soundness-Fee.............................. 67

Publishing ${ }^{-}$False Pedigrees, etc., Penalty.

VETERINARIAN (STATE.)

Compensation of Assistants..1..... 79 Compensation of Inspection. Paid by Whom.............................. 80 Compensation of Veterinarian Surgeon............... 79

Co-operate With inited States.. 78 DISEASED STOCK AND QUARANTINE LAWS:

Destruction of Stock-Compensation-Appeal................................ 73

Duties-Deputies............................. 78

Expenses.......................................... 79

Inspection of sheep From Outside the. Stable.................... 80

Penalty for Interfering witl ........ 73

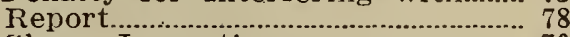

Sheep Inspection............................... 79

State Veterinarian surgeon $\mathrm{Ap}$ -

pointment, Powers, Regulations 73

'Treatment of Diseased Sheep...... 79

\section{RAILROAD RULES AND REGULATIONS.}

CARS:

Bedding in Car's. 119

Calves in Double-deck Cars........112

Cow Ponies-Carloads....................112

Feed in Stock Cars........................119

Furnishing Cars of Different

Size than Ordered.........................112

Goats, Carloads................................11.

Hogs in Double-deck Cars-Car-

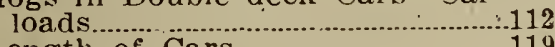

Length of Cars.....................................119

Ordering Cars .....................................112

Mixed Cars .......................................11,

Palace Horse Cars, Description?

Fiental Charges, etc. (Arms,

Doud, Keystone, Nather, Street) 115

Sheep in Jouble-deck Cars..........112

Sheep in Tiered Cars.....................11

Special or Palace Cars

Weighing of Horses and Mules,

Carloads...........................................115

IVestbould, stock Cattle, Stock

Homs and Stock Sheep, Double-

deck.

Contracts, Exxecuting.

119

(115

Dipped Sheep, Accepting..................112
Liability, Limitation of...................114 Re-consigning Tive Stock..............11

Shipments Without Caretakers.....1.14

STOPPING IN TRANSIT:

Fattenirg, Stopping in Transit of Cattle and Sheep for "Feed,

Rest or Sale, for........................ 117

Range Horses to Put in Condi-

: tion for Marketing:.........................117

To Finish Loading Horses,

Mules or Asses................................116

Transpoitation for Caretakers in Charge of Live Stock................112

WEIGH'S :

Allowance for Fill.

Kind of Live Stock, Weight, Rates-Mininu.m..........................120

Minimum Weights on Lire Stock Rated in. Cents per 100 lbs..................................................

Rated in Dollars per Car, Live stock Weights...............................118

Weights on Live Stock at Kansas City, Mo

\section{UNITED STATES LAWS AND SANITTARY REGULATIONS.}

Acts of Congress under which the regu'ations are made....................106

Appropriation 94

Farm names, Registrations of........ 94

Funds not to be used for private purposes

\section{4}

General regulations.

95

Fog cholera and-swine plague, requlations to prevent the spread of..

interstate shiprnent.
Maladie Du Coit, regulations to prevent spreading..........................10 104

Name, registered, cancellation of -fee ........................................... 9

Registration of firn: name authorized, etc........................................... 94

Regulations of the Secretary of Agriculture .................................. 95

Fielease, twenty-eight hour...........110

scabbies in cattle, regulations to prevent ............................................. 99

Scabbies in cattle, regulations to prevent spread of...........................102 


\section{South Omaha Live Stock Commission Firms}

Acker, N. E. \& Co.

Benton, VanSant \& Lush.

Big 4 Live Stock Commission Co.

Bliss, Joseph \& Son, Co.

Bliss \& Wellman.

Bowles Live Stock Com. Co.

Brainard \& Carpenter.

Buchanan, Alex G. \& Son.

Bulla, J. H. \& Co.

Burke, Rickley Co.

Byers Bros. \& Co.

Clay, Robinson \& Co.

Clifton Commission Co.

Clow, Byron \& Co.

Cox-Jones-Van Alstine Co.

Dennis \& Francis.

Denny, W. F.

Donahue, Randall \& Co.

Dudley, Allen \& Co.

Dworak Commission Co.

Farmers Live Stock Com. Co.

Frazier-Johnson Co.

Frederick, John T., \& Co.

Garrow Com. Co.

Great Western Com. Co.

Hamilton, H. F., \& Co.

Harvey, John, Jr.

Hill \& Son.

Interstate Com. Co.

Jackson-Signall Co.

Knollin Sheep Com. Co.

Laird, J. N. \& Co.

Laverty Bros.

\section{Sioux City Live Stock Commission Firms}

Babcock \& Son.

Baldwin, Kitselman \& Timmer.

Clay, Robinson \& Co.

Craighead \& Co.

C. Frederickson \& Co.

itzsimmons-Pierce Commission Co. Swanson \& Gilmore.

Frank E. Scott Commission Co.

Higgins Sheep Commission Co.

Ingwerson Bros.

Iowa Commission Co.

Kloek \& Vickers.

Lee Live Stock Commission Co.

Long \& Hansen.

Anderson, L. M.

Birmingham, Grover.

Birmingham, E. H.

Carbaugh, D.

Maurice Degen.

S. Dryfoos \& Son.

J. A. Flanders.

F. D. Foster.

L. C. Hudson.

Keenan, W. H.

William S. Carson
Lee Live Stock Com. Co.

Lewis, Frank P.

McCreary \& Kellogg.

Martin Bros. \& Co.

Melady Commission Co.

Missouri \& Kansas Calf \& Cattle Co.

Murphy, J. W.

National Live Stock Com. Co.

Nye-Schneider-Fowler Co.

Perry, W! J. \& Co.

Ralston \& Fonda.

Record Live Stock Com. Co.

Roberts Bros. \& Rose.

Roberts, L. E. \& Co.

Root, J. B. \& Co.

Rosenbaum Bros. \& Co.

Rosenstock Bros. \& Co.

Schwartz \& Co.

Smith Bros. Commission Co.

Smith, Wm. R., \& Son.

Snyder-Malone-Coffman Co.

Snyder, Son \& Co.

Standard L. S. Com. Co.

Tagg Bros.

Van Sant, W. B. Co.

Wiertheimer \& Degen.

Williams \& Sons.

Winn Bros.

Wood Bros.

Wood, Geo. M., Sheep Co.

Wood-Oswald-Childs Co.

Hudson \& Greenameyer.

Hefner Bros.

Moss \& McGee.

Rice Bros.

Rosenbaum Bros. \& Co.

Sioux City Live Stock Commis. Co.

Steele, Siman \& Co.

Snyder, Son \& Co.

Ward Commission. Co.

Wiood Bros. \& Co.

Waitt \& Lake Commission Co.

E. H. Schloeman \& Co. (Horse)

YARD DEALERS.

A. J. Lynch.

Marx \& Co.

Reilly \& Sullivan.

Rosenstock Bros.

W. E. Sheridan.

T. J. Steele \& Co.

C. B. Thorpe.

Throckmorton Bros.

H. E. Waitt.

A. S. W'endel.
Omaha Live Stock Com Co. 


\section{Mr. Stockman}

In putting out this edition of the "Stockmen's Legal Guide" we were prompted by a two-fold purpose. One was that we felt that it would be a most welcomed addition to your library, placing, as it does, the stock laws in force in your state, at your finger tips. The other was, that we wanted your business. *

When you buy, feed and sell on a close margin it is absolutely essential that yoube protected for the careless handling in ship. ment-for by one neglegent act on the part of a railroad your profits for an entire year may be sent glimmering.

We are fully prepared and qualified to recover theselosses for you-giving them the careful and prompt attention to which they are entitled.

We respectfully solicit your business.

Very truly yours,

\section{Stockmen's Claim Association}


Phone Douglas 1475

00009238542

All Modern Conveniences.

Rates $50 \mathrm{c}$ to $\$ 2.00$ per day

Special Weekly Rates

\section{The Oxford Hotel EUROPEAN PLAN \\ Cafe in Connection}

A. WHITE, Proprietor 11th and Farnam Sts. OMAHA, NEB.

\section{Hesitation is the Sign-Post on the Road to Failure}

$D O W N$ in your heart you know that a finished course of training in Book-keeping, Stenotypy, Shorthand and English or bothwould add mightily to your efficiency, would gain for you a genuinely good position in the business world and would push you forward on the path to promotion. And. if youl are not already sure of it, a little investigalion of the honest facts will convince you that your duty to yourself is to obtain that training in the

Write for National Business Training School, Sioux City, la.
Catalog

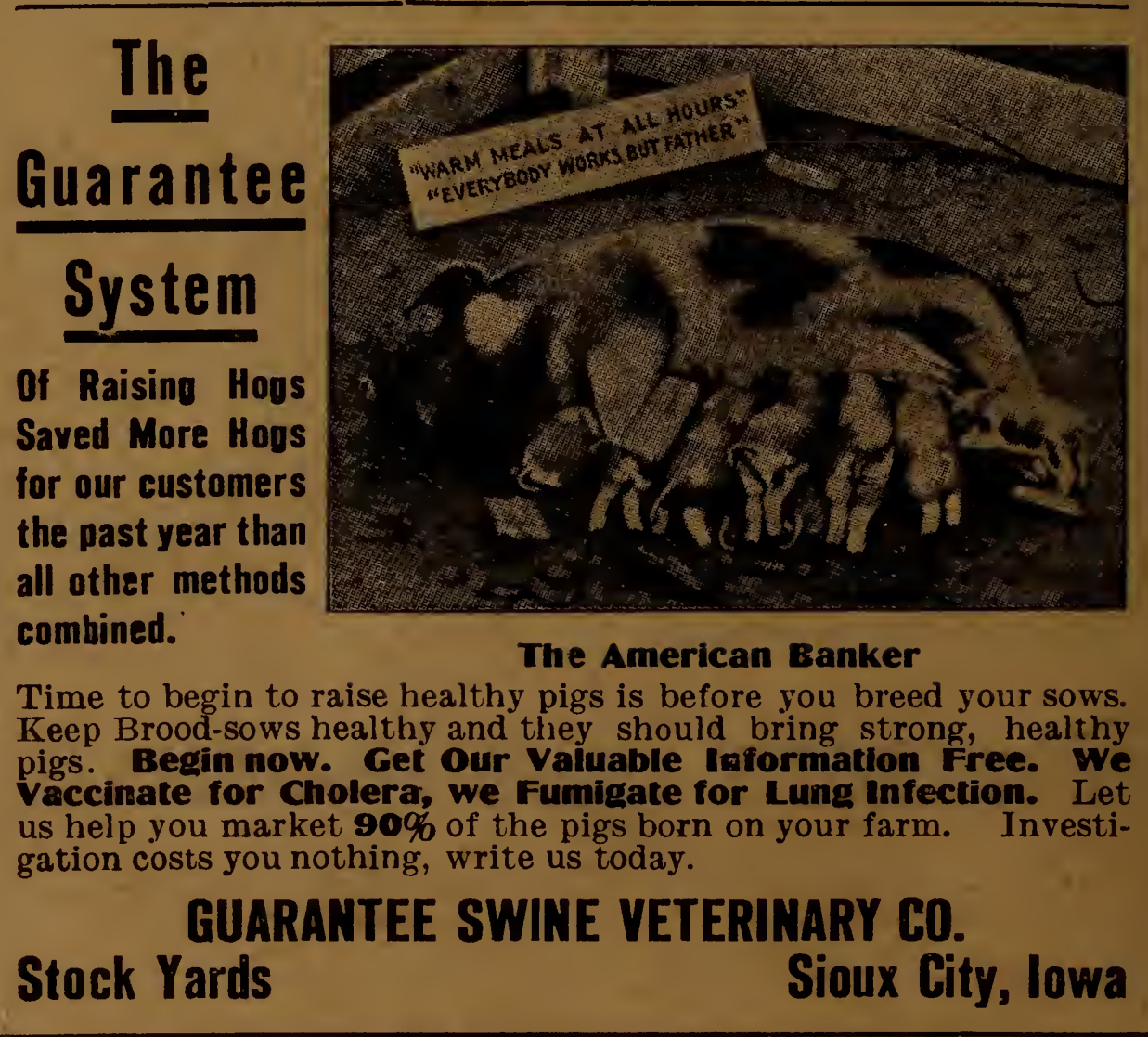

